Portland State University

PDXScholar

11-17-1993

\title{
The United States-Japan Security Treaty of 1951: An Essay on the Origins of Postwar Japanese-American Relation
}

Christopher S. Johnson

Portland State University

Follow this and additional works at: https://pdxscholar.library.pdx.edu/open_access_etds

Part of the Political Science Commons

Let us know how access to this document benefits you.

\section{Recommended Citation}

Johnson, Christopher S., "The United States-Japan Security Treaty of 1951: An Essay on the Origins of Postwar Japanese-American Relation" (1993). Dissertations and Theses. Paper 4596.

https://doi.org/10.15760/etd.6480

This Thesis is brought to you for free and open access. It has been accepted for inclusion in Dissertations and Theses by an authorized administrator of PDXScholar. Please contact us if we can make this document more accessible: pdxscholar@pdx.edu. 
AN ABSTRACT OF THE THESIS OF Christopher S. Johnson for the Master of Science in Polical Science presented November 17, 1993.

Title: The United States-Japan Security Treaty of 1951: An Essay on the Origins of Postwar Japanese-American Relations.

\section{APPROVED BY THE MEMBERS OF THE THESIS COMMITTEE:}

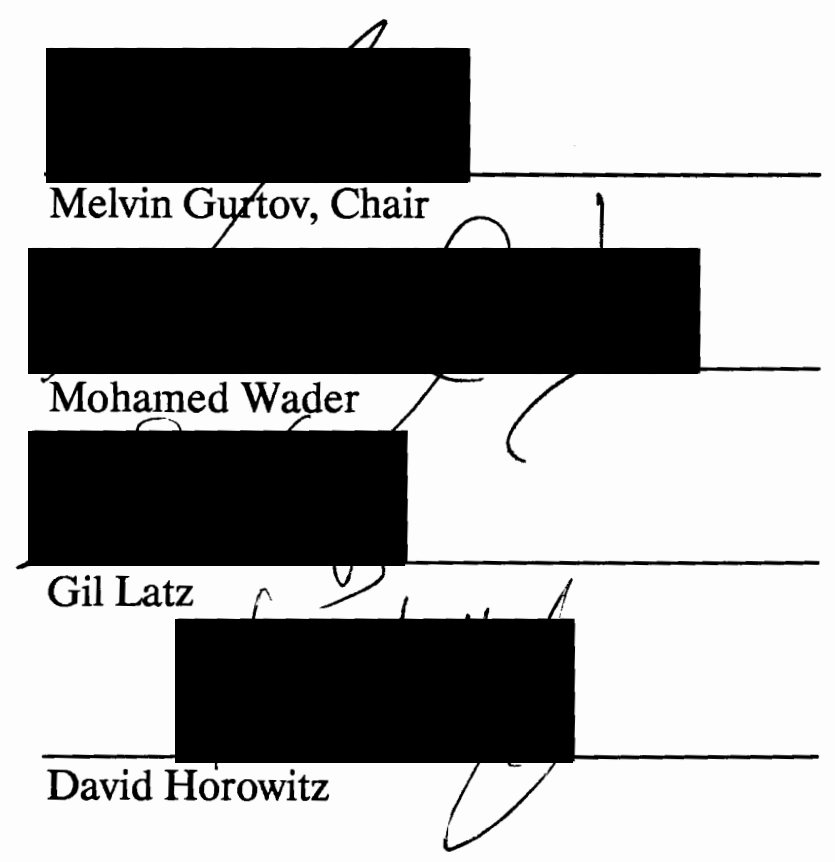

The early September day in 1951 that brought the Pacific War to an official end, with the signing of a treaty of peace, concluded as representatives of Japan and the United States signed the Bilateral Security Treaty. The security treaty symbolized new realities of international relations, just as the peace treaty had buried the old. By cementing into place a strategic alliance between the former Pacific antagonists, the treaty represented the great and lasting achievement of postwar American diplomacy 
in Asia. Nevertheless, the treaty was both the outcome and the perpetuation of a stereotyped and lopsided relationship, now fixed firmly into place, as a Japan diminished by defeat acceded to the necessity of a security embrace with its former conqueror, and the United States enlisted a most valued, albeit a most reluctant ally for the ongoing struggle to meet and defeat the Soviet threat.

At the end of the Pacific War such an outcome had been beyond the pale. The security treaty was the product of years of crisis adaptation. Hopes that the U.S. could make China the great power of Asia were dashed by revolution. As cherished verities of U.S. diplomacy fell by the wayside, new truisms, based upon strategic interests inherited from victory in the Pacific and the cold war policy of containment, staunchly rose to assume their place. As a result, U.S. attitudes towards Japan underwent a tortuous reassessment. The initial occupation policies of disarmament and reform were replaced by the urgent need to enlist Japan as a vital cold war asset. However, this reorientation was not easily accomplished. Competing interests within the U.S. Government clashed over the means necessary to insure Japan's security and stability, while also guaranteeing the creation of a reliable ally -- a debate that became ever more heated as the cold war intensified. The Japanese, at great disadvantage, skillfully attempted to negotiate a role for themselves in the postwar world, eager for an alliance, yet fearful of domination. The goal of this thesis is to chart and document the evolution of this policy transformation, in all its twists and odd turns.

To accomplish this task I turned to an older tradition of political science, one widely practiced at the dawn of the discipline. To be sure, judicious use was made of 
many of the theories and methodological approaches prevalent currently. Yet while useful at times, these methods often failed to adequately explain those indeterminate moments of idiosyncratic chance and contingency of events upon which so much, to my mind, the final outcome depended. I turned therefore to a more historical approach. My primary sources became the diplomatic record as revealed in the Foreign Relations of the United States and the memoirs of those who participated in the fashioning of the U.S.-Japan Security Treaty.

By the time the security treaty was concluded, the agreement reached was not one of shared joint purpose, but one which defined and gave sanction to diverging national aims that could not, nonetheless, be realized in isolation. The continued U.S. military presence in Japan had been the goal of a policy process ultimately defined in military terms, as the final bastion of cold war containment on the rim of Asia. The Japanese understood the need for security in a volatile world, but not the necessity of providing it for themselves, as the postwar political system slowly organized around emerging economic priorities. It was an odd arrangement, but one which met respective needs and desires. Yet its lack of reciprocity and mutual commitment has ensured through the years the continuation of an ambiguous and uncertain alliance. 
THE UNITED STATES-JAPAN SECURITY TREATY OF 1951:

AN ESSAY ON THE ORIGINS OF

POSTWAR JAPANESE-AMERICAN RELATIONS

by

CHRISTOPHER S. JOHNSON

A thesis submitted in partial fulfillment of the

requirement for the degree of

MASTER OF SCIENCE

in

POLITICAL SCIENCE

Portland State University

1993 
TO THE OFFICE OF GRADUATE STUDIES:

The members of the Committee approve the thesis of Christopher S. Johnson presented November 17, 1993.

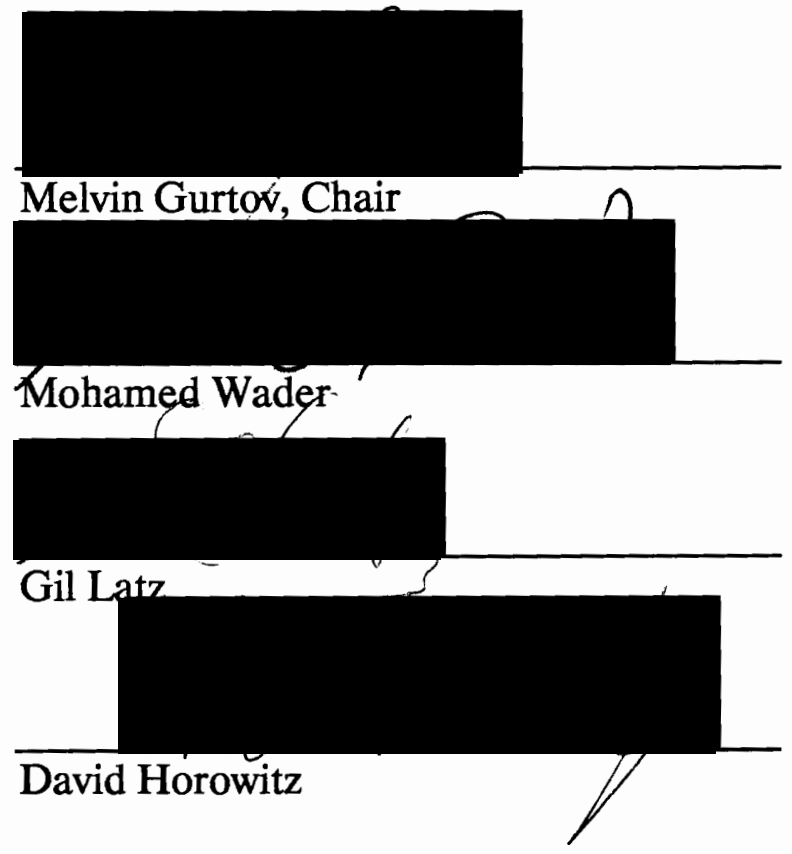

APPROVED:

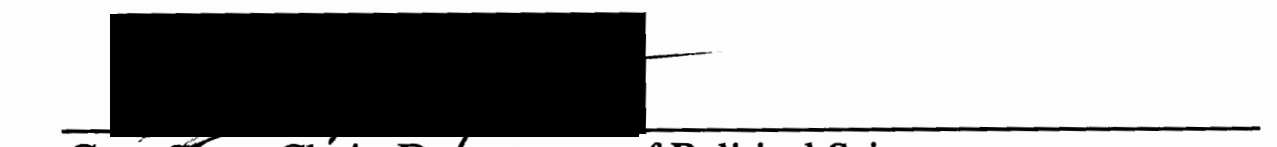

Gary Scott, Chair, Department of Political Science

Roy W. K $\phi c h$, Vice Provost for Graduate Studies and Research 


\section{ACKNOWLEDGMENTS}

Since brevity has so much to recommend it, and yet I so seldom comply with its dictates, here at least I shall be brief. I would first wish to thank the unsung librarians and staff of the Portland State Library Department of Inter-Library Loans for their remarkable efforts to procure faraway books in the timeliest way. Betty Cox, Office Coordinator of the Department of Political Science, held my hand more often than I would want to recall, as she helped me arrange many of the details which I was too incompetent to see through for myself. I wish to thank the efforts of my committee: Mohamed Wader, Gil Latz and David Horowitz (scholars all), who devoted precious time on my behalf. My advisor, Melvin Gurtov, is due special words of praise for guiding me, ever so gently, through an enterprise which at times I am sure he felt had no end. My devoted and long suffering wife, Katherin Kirkpatrick endured much of the worst with genuine, I believe, good humor and understanding. And finally, an immense bundle of gratitude is due my parents, Stephen and Joan Johnson, who most generously bankrolled the entire venture. 


\section{TABLE OF CONTENTS}

PAGE

ACKNOWLEDGMENTS $\ldots \ldots \ldots \ldots \ldots \ldots \ldots \ldots \ldots \ldots \ldots \ldots \ldots \ldots \ldots$ iii CHAPTER

I INTRODUCTION $\ldots \ldots \ldots \ldots \ldots \ldots \ldots \ldots \ldots \ldots \ldots \ldots \ldots \ldots$

II LEGACIES OF WAR ........................ 7

Marshall and China ........................ 8

The Occupation and Article IX $\ldots \ldots \ldots \ldots \ldots \ldots \ldots 11$

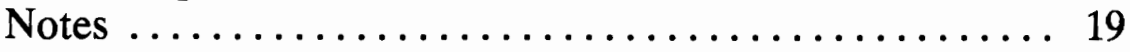

III THE EARLY PEACE $\ldots \ldots \ldots \ldots \ldots \ldots \ldots \ldots \ldots \ldots \ldots . \ldots \ldots$

The Prime Minister and the Japanese Past ......... 28

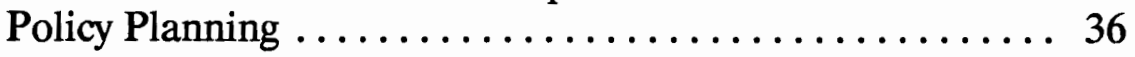

The Ashida Notes ....................... 40

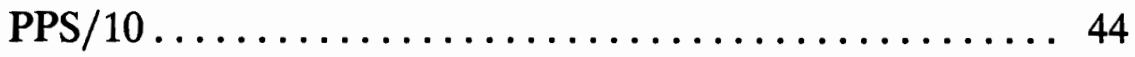

Notes ............................. 47

IV REORIENTATION: THE KENNAN MISSION AND NSC

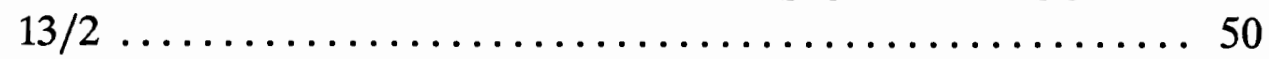

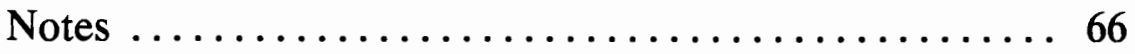

V "PENTAGONIZATION" ..................... 70

Permanent Neutrality $\ldots \ldots \ldots \ldots \ldots \ldots \ldots \ldots . \ldots 94$

Notes ................................. 104

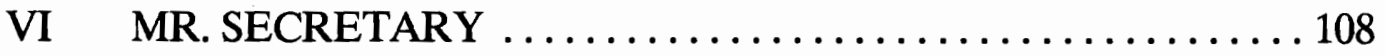

The Soviets in Asia ............................. 111

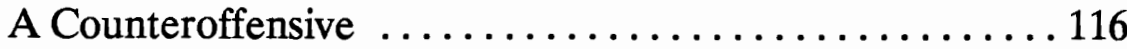

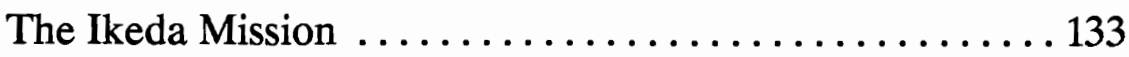

A New Cast of Characters ....................... 139

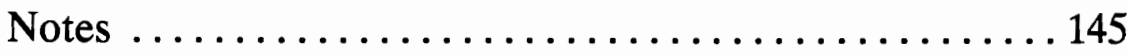


VII JOHN FOSTER DULLES AND THE IMPACT OF KOREA . . 149

"Saved" ................................ 161

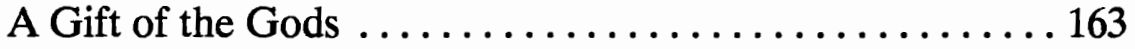

The End of an Impasse ..................... 172

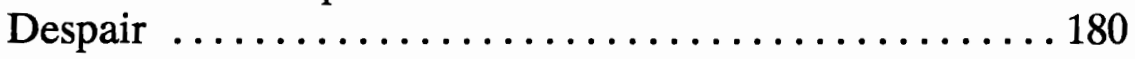

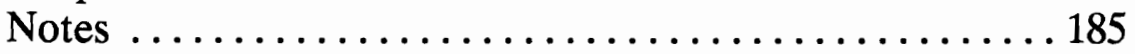

VIII THE AMBIGUITY OF COMPROMISE .............. 190

Endgame .............................. 192

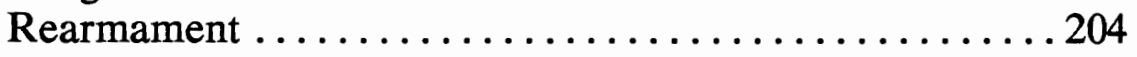

Finishing Touches $\ldots \ldots \ldots \ldots \ldots \ldots \ldots \ldots \ldots \ldots 208$

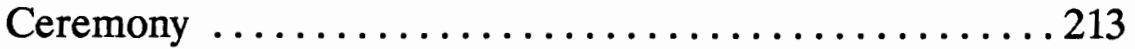

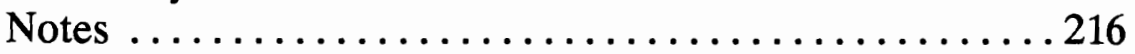

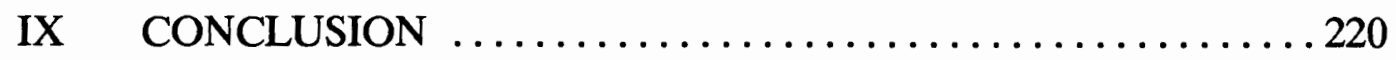

Notes ..................................229

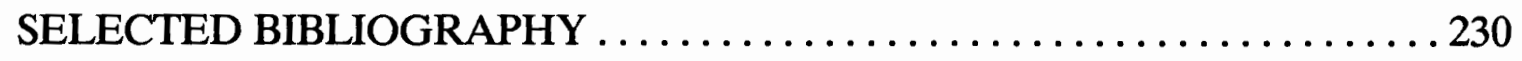

APPENDIX A

Article IX of the Japanese Constitution $\ldots \ldots \ldots \ldots \ldots \ldots \ldots \ldots \ldots \ldots$

\section{APPENDIX B}

Text of the United States-Japan

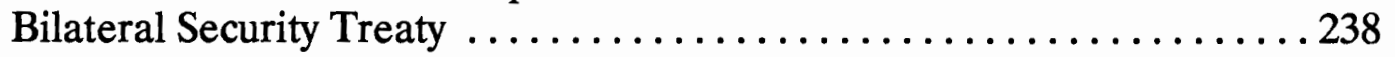




\section{CHAPTER I}

\section{INTRODUCTION}

Relations between nations seldom arrange themselves fortuitously solely by the happy caprice of history. Of recent years the fashioners of U.S. foreign policy have come to term this country's relations with Japan as "the most important bilateral relationship in the world." What they mean to convey by this dry diplomatic phrase is something more than the somewhat grim ritual asseverations of determined friendship. It is rather the reassuring confirmation of a long standing strategic and political arrangement. The most important bilateral relationship in the world is centered upon fundamental military considerations which economic disputes, however serious, have not as yet undone. It is one of the bedrocks of United States foreign policy of the postwar era.

As the cold war recedes, its origins now stand in starker relief, if only because we now know how this story ends. At the heart of the confrontation lay a bitter struggle to control the destinies of the two defeated powers of the Second World War, Germany and Japan. Though in ruins, their human and industrial potential would greatly determine the strategic balance of power in the world to come. Thus, to secure Japan to the side of the "free world" became the great overriding goal of United States Far Eastern policy. The evolution from enemy to potential ally posed numerous problems, and none more so than the peculiar and knotty difficulties 
involved in providing for the security of an independent, but demilitarized and economically fragile Japan, without compromising that of the United States. The story of how this was accomplished is what I hope to relate in the pages to follow, and in the attempt, to locate some of the ambivalence which surrounds the uneasy friendship shared by the two Pacific rivals.

An occasionally unsteady gaze will focus upon a critical period -- from the beginning of the year 1947 to the end of 1951 . The signing that year of a bilateral security treaty between Japan and the United States was the culmination of a half decade of swift and astonishing change that witnessed the remaking of U.S. policy toward its former enemy not once but many times. By the conclusion of this sometimes comic and occasionally ghastly process of reconfiguration, the primacy of security had emerged triumphant from a competing hierarchy of policy aims and values. The hows and the whys of that process deserve a fuller examination. For in many ways the final outcome was but the insubstantial shadow of a deadly serious struggle waged within the U.S. Government. It was a drama shaped, to be sure, by the tenor of the times and its preoccupations; it was nevertheless the character of this struggle, its winners and losers, its compromises and defeats, which determined, far more than ultimate policy directions and decisions, the shape and direction of the future.

Ranging as it did over years, and encompassing many issues rife with the gravest of implications, this conflict over Japan's proper position in the world took any number of forms. At the broadest, most sweeping level was a conflict of the 
mind, of ideals and beliefs in contention with the world. Unconditional surrender was grasped as an invitation to eliminate the evil of rampant militarism from the world. Transgressors would be punished, then, in the image of their conqueror, made anew. A tradition of Wilsonian idealism informed the American occupation of Japan, girded by a liberal faith in the institutions of a democratic society; and its early optimism was but a reflection of a paternalistic belief in the ability of men to realize their utopian aspirations by a recognition of the futility of arms and war. But moral principle could not undo political realities. The balance of power was not eliminated, only transformed. Undeniably, the cold war too, had its elements of moral crusade and indignation, but they served as mere accessories to the stony realism of power politics and national self-interest, not as ends in themselves. As the vision of Soviet power impinged ever more upon American perceptions, the ideals of the past and the urgent necessities of the present collided, and from the wreckage the role of Japan within the Pax Americana was remade.

It would nonetheless be wrong, and overly simplistic, to paint the clash as a rigid dichotomy between the ranks of "idealists" and their "realist" counterparts. Ideology was in no sense monolithic, but was very much a captive of institutional prerogatives and interests. The evolution, or perhaps revolutions, of U.S. policy towards the Japanese was largely the consequence of a relentless competition amongst bureaucratic entities of the U.S. Government to gain for themselves the power and privilege of refashioning a devastated and supine nation. The struggles between Occupation authorities in Tokyo and policy makers in Washington, 
between the Department of State and the Department of Defense, and even at critical times within the halls of Foggy Bottom itself, lent the evolving drama the quality of a Darwinian contest of survival of the fittest, as issues of military expediency confronted larger political considerations.

Yet even this was often not as cut and dried as it sometimes seemed. The frequently confused state of American policy was but a hint of the true dimensions of underlying chaos; of secret stalemates and shifting alliances working all too often at cross purposes. These were in turn influenced and intersected, sometimes decisively, by pivotal events within the larger context of the cold war. Nor to be neglected, I hope, was the astute role of the Japanese themselves, who, perhaps because they had more to lose but very limited options indeed, exercised an acute sensitivity to their own interests and advantage.

Yet faceless bureaucratic battles these decidedly were not. Though it is unfashionable, I cannot but help champion notion that individual agency and personal idiosyncrasy shaped the direction and outcome of events. The role of life history and experience, individual temperament, and personal animosities were at many a critical juncture decisive and irrevocable. Just a short list of the names of those who pasted their influence upon the making and remaking of American policy in Japan -- MacArthur, Acheson, Dulles, Kennan, Yoshida -- renders it impossible to study these events without hearing the insistent clang of outsize personalities in collision. 
Which brings me to a consideration of the methods, and limits of this study. I came to the work with few preconceived notions, no models or theories to uphold. This choice of methodology was not chosen out of mere perversity. Models, theories, and other generalizations that form the bulk of the practice of social science ultimately fail to account for all the factors of discrete, unrepeatable situations. Such techniques are indeed useful tools for discerning analogy and pattern, but I have made only limited use of them because my aim was not to fashion a system of universalistic explanation or predictive power, but rather (and perhaps more prosaically) to describe and account for a unique sequence of events, sifting through the myriad factors, as I could determine them, that led to a particular outcome. My goal was to attempt to arrive at an understanding of the past, limited though it might be, by tracing and weighing the internal course of events.

To accomplish my task I turned to an older tradition, one more widely practiced at the dawn of political science than is the case today. I was determined to look to my sources -- consisting primarily of that vast and splendid archive of this nation's diplomacy -- the Foreign Relations of the United States series, and the memoirs, when available, of those persons most intimately associated with the fabrication of U.S. security policy in Japan and East Asia during the late 1940's and early 1950 's -- with a fresh, and I hope, engaged eye. In doing so I was following a method of close, sensitive textural study and analysis: a tradition best exemplified by the two volumes of Kennan's Memoirs, the work of Akira Iriye (especially Across the Pacific), and that now nearly forgotten masterwork which I have conceived my 
study as a humble attempt at continuation, A. Whitney Griswold's The Far Eastern Policy of the United States. And while I do not claim this level of distinction for my own work, I have tried to achieve something of its scrupulousness.

Ineluctably however, this approach led me to emphasize, perhaps excessively, the doings of American officialdom at the expense of their Japanese counterparts, thereby relegating them to a reactive and secondary place. This may be justified to the degree that this was symptomatic of the U.S.-Japan relationship (which I believe it was), but less justified to the extent that it shows a grievous absence of primary Japanese sources and my own lack of facility in the Japanese language. Lastly, my own narrow fixation upon the dilemmas of security has left a train of important economic and political issues unbroached or only lightly touched upon in these pages.

Subject to unconditional surrender, and stripped of army, navy and empire, Japan looked to its erstwhile occupier to grant external protection from those threatening, if often ambiguous, cold war realities which its own meager resources could not provide. The role of Japan's international bodyguard, assumed out of perceived necessities and self interest by the United States, was nevertheless taken up with the understanding that it was to be a highly provisional, not a perpetual measure. Yet relationships have a way of fostering the conditions under which they thrive. In a sense, both parties remain trapped by a shared history. One, it is my hope, that I have been able to render less opaque. 


\section{CHAPTER II}

\section{LEGACIES OF WAR}

In the melancholy winter of 1950 , George Kennan, diplomat and scholar, addressed a series of lectures to an audience at the University of Chicago. As he spoke, on the other side of the world, U.S. forces had already retreated nearly 300 chaotic miles down the Korean peninsula, obliterating the gains from MacArthur's brilliant gamble at Inchon only a few short months before. Kennan implored his listeners to ponder the ongoing disaster from the comfortless vantage of history, and left them with a pointed, if rhetorical, query:

Today we have fallen heir to the problems and responsibilities the Japanese had faced and borne in the Korean-Manchurian area for nearly half a century, and there is a certain perverse justice in the pain we are suffering from a burden which, when it was borne by others, we held in such low esteem. What is saddest of all is that the relationship between past and present seems to be visible to so few people. For if we are not to learn from our own mistakes, where shall we learn at all ${ }^{1}$

It was, nonetheless, an inheritance which United States decision makers, having never sought, had not, except for the cryptic warnings of a few unheeded men, anticipated either. So it is not too surprising that the United States was ill prepared to assume a burden which it had never seriously considered or desired. As Kennan's pessimistic assessment suggests, however, if there is fault to be found, it does not lie in a failure to achieve omniscience, but in a failure of empathy and 
imagination, and an inability, rooted in moral righteousness and condescension, to adequately ponder the probable consequences of certain actions and to recognize a responsibility for bringing them about.

\section{MARSHALL AND CHINA}

Well before the end to the Pacific War, U.S. leaders and policy makers had already fabricated a rather detailed picture of the East Asia to be brought forth, under American auspices, at the time of the war's conclusion. President Roosevelt's Secretary of State, Cordell Hull had, by the beginning of 1943, become an enthusiastic advocate of the position that the logical conclusion of a half century of U.S. policy towards China, euphemistically known as "the Open Door," should culminate in the bestowal of the status of a Great Power. When Winston Churchill admonished that, due to China's weakness and the likelihood of future instability, its status as a post war power was bound to be elusive, his remarks, and others like them, were dismissed as a cynical attempt to disguise Britain's imperial aspirations.

In the end U.S. views were the ones to prevail. At the release of the Cairo Declaration in December 1943, which pledged the allies to the destruction of the Japanese empire, the signature of Chiang Kai-Shek was affixed alongside those of Roosevelt and Churchill. In his memoirs Hull voiced the belief that would guide U.S. policy regarding the future of East Asia:

Japan would disappear as a great Oriental power for a long time to come. Therefore, the only major strictly Oriental power would be China. The United States, Britain, and Russia, were also Pacific powers, but the greater interests of each were elsewhere. 
Consequently, if there was ever to be stability in the Far East, it had to be assured with China at the center of any arrangement that was made. $^{2}$

It was a policy culled from a deep reservoir of wishful and well-meaning sentiment with a long tradition behind it; an ultimately self-defeating tradition firmly buttressed by a paternalistic delusion that the United States was the protector of a supine but thankful China's political and administrative integrity against the bully boys of European, and later, Japanese colonialism. Only a powerfully naive man could believe, as Hull apparently did, that the brutal and compromised regime of Chiang Kai-shek "followed faithfully in the footsteps of Sun Yat-sen," and that Chiang himself was "was wise and patriotic." ${ }^{3}$ Unfortunately, Hull was not alone in this appraisal, which was shared by many members of congress and powerful figures in the media, such as Henry Luce.

While so much of the lofty U.S. plans for Asia were riding on the viability of China's postwar government, the bitterness and frustration experienced by American military and diplomatic personnel in exacting cooperation from the touchy generalissimo was a more accurate gauge from which to measure both the health of the regime and the relationship. As late as December 1944, U.S. officials toyed with the idea of forging an alliance between Chiang and the Communists, but it came to nothing. ${ }^{4}$ After Japan's defeat, U.S. officials, now with a host of new and urgent preoccupations, grew less indulgent towards the open corruption of Chiang's regime, while ominous losses at the hands of Communist forces (which had received large caches of weapons after Soviet troops accepted the surrender of Japanese 
divisions in Manchuria) suggested that the $\$ 600$ million in military aid provided by the United States had not boosted military competence.

The tribulations of the Marshall Mission only accelerated the reappraisal of the Chinese situation in official Washington thinking, a process already under way. The former Chairman of the Joint Chiefs had been instructed by President Truman soon after his appointment as envoy in December of 1946 that he, Marshall, was to convey to Chiang that "a China disunited and torn by civil strife could not be considered realistically as a proper place for American assistance," and to push for political reforms. By August 1946, Truman personally suggested to Chiang, by letter, that a reversal of American policy and a withdrawal of American aid was imminent. "American faith in the peaceful and democratic aspirations of the Chinese people has not been destroyed," Truman wrote, "but has been shaken." If reforms were not pressed and serious negotiations with the communists not undertaken, Truman sharply concluded, he would be forced to "redefine and explain the position of the United States," to the American people. By this time Chiang's regime was beyond U.S. attempts to resuscitate it, and China's civil war would permit only of military solutions. In January 1947, before returning to Washington to become Truman's Secretary of State, General Marshall announced that his mission had ended in failure. ${ }^{5}$ 


\section{THE OCCUPATION AND ARTICLE IX}

The objectives were unequivocally stated on August 29, 1945. "Disarmament and demilitarization are the primary tasks of the military occupation," instructed the Basic Initial Post-Surrender Directive to its primary recipient, General Douglas MacArthur, "and shall be carried out promptly and with determination." The paramount duty before the imperious General, now to assume the role of Supreme Commander of the Allied Powers (SCAP), would be "to insure that Japan will not again become a menace to the United States or to the peace and security of the

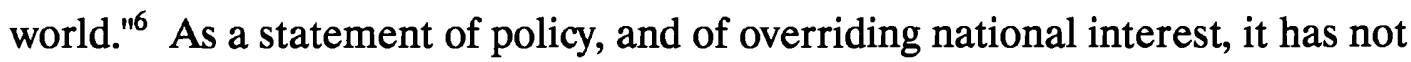
been superseded to this day.

It is no exaggeration to suggest that the history of the seven subsequent years can not be fully understood unless this overriding objective of United States policy towards Japan is weighted with the significance that it assumed in the minds of those whose experience was first shaped by the exigencies of the war in the Pacific. The policy of the United States was conducted with a view towards affirming its fundamental importance, regardless of the shape of future conflicts. The differences lay in the changing views of how it was to be realized under altered and difficult circumstances. To suggest that subsequent U.S. policy in Japan was driven solely by an atmosphere of cold war confrontation have missed a crucial element of its primary dynamic, its essentially preventive nature.

The Potsdam Declaration had been the first official statement to commit the United States to the expunging of military influence in Japanese national life, to be 
effected during the course of the occupation regime which was to follow the war's conclusion. But something else was pledged at Potsdam, a correlation to the removal of martial ascendancy; a thoroughgoing program of democratic and liberal reform, in which elementary western freedoms of thought, speech and religion were to be established.

The Occupation thus inherited a mandate to conduct experiments on a vast scale in benevolent social engineering. They were, in addition, experiments of a decidedly American hue, because though nominally an instrument of the allied powers, the offices of the Occupation were overwhelmingly staffed by personnel of the Armed Forces of the United States, right up to the Supreme Commander himself. Justified by the indisputable fact that it was the United States which had born the brunt of the war against Japan, the arrangements reflected a deep desire on the part of the highest levels in the U.S. government to avoid the difficulties that had already surfaced in the multi-national occupation of Germany.

This unique set of circumstances, wherein the Supreme Commander held rank as an officer of the United States (as Commander in Chief, Far East CINCFE), but his authority as head of the Occupation did not stem directly from the U.S. Government, had the effect, unintended or not, of conferring sovereignty on the person of General MacArthur. From his office in the Dai-Ichi Hotel in central Tokyo across from the Imperial Palace, as the General set about his business of reinventing Japanese society, whether purging politicians or dismantling old institutions and industries, he did so largely beyond the reach and influence of the 
President and Secretary of State (accordingly, MacArthur "would not even hear of State Department advice"), ${ }^{7}$ and even, except in the most dire of circumstances, beyond that of the War Department and the Joint Chiefs. Wholeheartedly dedicated to the foisting of an idiosyncratic, Americanized vision of democracy upon a vanquished alien people, all the while the Occupation, a vast bureaucratic entity with its own perspectives and interests, lay remote from the legal authority of the United States.

If the idealistic reformers of the Occupation were unhampered by meddling from Washington, it could not be said that they were free to go about their business unimpeded. On the one hand they were hindered by a blithe ignorance of the people and society they had set about to transform. ${ }^{8}$ Yet a more serious difficulty grew out of the initial design of the occupation itself, as authoritatively stated in the Basic Directive: "In view of...the desire of the United States to attain its objectives with a minimum commitment of its forces and resources, the Supreme Commander will exercise his authority through Japanese government machinery and agencies...to the extent that this satisfactorily furthers United States objectives." ${ }^{\prime 9}$ To implement far-reaching reform amidst chaos and demoralization was a daunting enough task, but as George Atcheson, Political Advisor to SCAP, glumly confessed in November 1945, there were greater monuments of obstruction:

Practically all categories of Japanese show or pretend a desire to cooperate with our military, but the civil officials and bureaucracy are the least sincere and effective....And in any serious effort toward reform, cabinet ministers who may overcome their near incapacity to adapt themselves to the progress of events are confronted, often to the point of helplessness, by the obstructionism of the unregenerate 
and deeply entrenched bureaucrats. They carry out directives but seem incapable of solving many of the administrative and most of the economic problems with which the government is faced. ${ }^{10}$

On October 16, 1945, General MacArthur declared the complete demobilization of the Japanese Armed Forces. "This ends its military might and its military influence in world affairs," he announced, "Its path in the future, if it is to survive, must be confined to the ways of peace."11 ${ }^{11}$ Yet, for all of the General's orotundity, the path of peace remained a slippery one, and begged the fundamental question of just how Japan was to keep to the straight and narrow once the Americans, who could not stay forever, departed.

There was a widespread belief within SCAP that the Japanese Constitution, promulgated by the Emperor Meiji in 1889 , must be abolished or wholly remade if Occupation objectives were to be realized. The Constitution was taken to be at the root of Japan's social ills, a document hostile to the development of democracy and fostering the growth of militarism and oligarchy. In early 1946, when Japanese leadership proved unable or unwilling to produce a document to his specifications, MacArthur instructed General Courtney Whitney of Government Section and his staff to author a constitution which would, in a controversial move, provide for the retention of the Emperor as constitutional monarch, uphold the principles of universal suffrage, and enshrine the renunciation of war. ${ }^{12}$

By MacArthur's account, recorded in his Reminiscences, the resolve to forswear war as a constitutional principle emerged from a conversation held with then Prime Minister Shidehara ${ }^{13}$ in late January 1946. Whether in a burst of 
heartfelt idealism, or in a desperate, if indirect attempt to preserve the emperor system $^{14}$, Shidehara proffered that the constitution include a provision to "prohibit any military establishment," a pledge which would prove to the world "that Japan never intended to wage war again." MacArthur's lofty assent to the idea apparently "overwhelmed" the other man to the point that "tears ran down his face." Staggering in amazement from the weight of so much concentrated greatness, Shidehara supposedly turned to the General as he departed to declare the SCAP, and himself, "visionaries" and "prophets." 15

The verity of such self-serving histrionics aside, there is little doubt that the inclusion of the anti-war clause was the vital ingredient of MacArthur's conception of the postwar Japan that he wished to bequeth to a grateful posterity. The calculations of a savvy realpolitik went undetected in the heady atmosphere of highmindedness: a constitutionally disarmed Japan would not "menace" the United States for a very long time. At the announcement of the new Constitution in early March 1946, the General proclaimed Article IX (as the anti-war clause was numbered) the "foremost of its provisions." The article stipulated that "the Japanese people forever renounce war as a sovereign right," and vowed that "land, sea, and air forces, as well as other war potential, will never be maintained." MacArthur, as was his habit, further pontificated on their meaning:

By this undertaking and commitment Japan surrenders rights inherent in her own sovereignty and renders her future security and very survival subject to the good faith and justice of the peace-loving peoples of the world. By it does a nation, recognizing the futility of war as an arbiter of international issues, chart a new course oriented to faith in the justice, tolerance, and understanding of mankind. ${ }^{16}$ 
But such faith lay grounded in a thicket of false pretenses. Beyond the obvious, but apparently unacknowledged fact that the world is an ever changing and treacherous place, and that it would be the Japanese, not its American authors who would bear the brunt of its consequences, the article reflected a peculiarly American mixture of naivete and misplaced idealism: the substitution of a moral ideal for political realities. It was a stand moreover that circumstance would soon force this nation to modify, though not entirely abandon. Rooted at its core was a notion, the product of an advantageous and insular history, that the causes of war were lodged in "bad" societies perverted from peaceful attainments because over burdened by institutions of repression, rather than the outcome of irreconcilable conflicts arising from the aims and aspirations of states. Given a conception of history viewed essentially in moral terms, the creed of American democracy was to be administered as an inocculation against Japan's social ills; as a cure for its "feudalism" and militarism. The American renovation of Japan was the most eminently justifiable of enterprises because the Japanese past was so tainted as to be beyond redemption.

The success of that undertaking, the Occupation's "reform from above," has, over the past decade or so, come under increasing scholarly scrutiny, both as to the sometimes unsavory and poorly considered methods which it employed, and as to its more exaggerated claims to have utterly transmogrified the object of its attention. ${ }^{17}$ Revisionists are certainly correct to point out the unmistakable elements of continuity with the pre-war past, and to note the rectification of "excesses" carried out by a conservative bureaucracy and political establishment as 
they overturned those vestiges of the Occupation which they considered uncongenial to Japanese traditions and threatening to their own political prerogatives.

If the Occupation ultimately failed to effect the total transformation of Japan's internal politics that fact should not blind us from recognizing one of its most vigorous legacies - the fundamental reorientation of Japan in its dealings with the world. Though Japan has never assumed that role assigned to it in MacArthur's daydreams as "the Switzerland of the Pacific" (one perhaps cherished by many Japanese as well), for the half century since the war Japan has remained aloof as a participant, though not as an object, of power politics. The transformation from aggressive builder of the only non-western empire in modern history to nervous adherent of the international idealism inherited from the early years of the Occupation could not be greater. That Japan should have originally adopted such a stance in the aftermath of total defeat, with the country and old verities equally in ruins, and a society both prostrate and genuinely receptive, is less surprising than that it should have been preserved despite the sometimes formidable pressures, internal and external, for its abandonment. The reasons for this stubborn adherence will be explored in greater detail elsewhere; for now it should simply be noted that behind the international facade of postwar Japan powerful economic and political interests were being forged that were quick to perceive and exploit the advantages to be gained when concealed behind pious expediency.

In Washington, far removed from the atmosphere of paternal arrogance and evangelical sense of mission which pervaded the offices of the Occupation in distant 
Tokyo, other priorities, other more immediate "menaces," had begun to pervade official consciousness by the end of 1946 . This gradual diverging of opinion was producing ever widening, even frightening gaps of perception, and not just between Washington and Tokyo. As some officials in Washington began to question, privately at first, and then publicly, whether the policies pursued by the Occupation were becoming dangerously obsolete, others worked assiduously to bring them to a perilous fruition. 


\section{NOTES}

1. George F. Kennan, American Diplomacy, Exp. ed. (Chicago: University of Chicago Press, 1984), p. 52.

2. The section from the memoirs of Secretary Hull were quoted in Frederick $\mathbf{S}$. Dunn, Peace-Making and the Settlement with Japan (Princeton, Princeton University Press, 1963), p. 29.

3. Ibid.

4. Jonathan D. Spence, The Search for Modern China (New York: W. W. Norton \& Company, 1990), p. 479.

5. All quotes from the preceding paragraph were taken from Ibid., p. 490.

6. Quoted sections of the Initial Basic Post-Surrender Directive were taken from Jon Livingston, Joe Moore and Felicia Oldfather, eds., Postwar Japan: 1945 to the Present (New York: Random House, 1973), pp. 7-9.

7. George F. Kennan, Memoirs: 1925-1950, vol. 1 (Boston: Little, Brown \& Company, 1967), p. 370.

8. A point made explicitly Prime Minister Yoshida, who further observed that the hubris of the occupation authorities helped to preserve an ignorance of their ignorance. Shigeru Yoshida, The Yoshida Memoirs: The Story of Japan in Crisis (Westport, Connecticut: Greenwood Press, 1973), p. 128.

9. Livingston, pp. 8-9.

10. Memo from Acting Political Advisor in Japan (Atcheson) to President Truman, Tokyo, November 5, 1945. U.S., Department of State, Foreign Relations of the United States, 1945: The Far East [hereafter FRUS] (Washington, D.C.,: U.S. Government Printing Office), pp. 825-827.

11. "Demobilization of Japanese Armed Forces," Political Reorientation of Japan September 1945 to September 1948, Report of Government Section, Supreme Commander of the Allied Powers (Washington, D.C.: U.S. Government Printing Office, 1949), vol. 2, Appendix F:7, p. 742. 
12. Much of the information culled for the preceding paragraph, and the one to follow was taken from Kenneth B. Pyle, The Making of Modern Japan (Lexington, Massachusetts: D.C. Heath and Company, 1978), pp. 156-160, and to which I am much indebted.

13. Shidehara Kijuro (1872-1951) served as Prime Minister from October 1945 to May 1946 for the period of demilitarization. His generally pro-Anglo-American policies during a long career in the Foreign Ministry made him acceptable to SCAP: including a stint as Ambassador to the United States, and as chief Japanese delegate to the Washington Naval Disarmament Conference of 1921-1922. Twice Foreign Minister, 1924-1927 and 1929-1931, he opposed the reckless military expansionists during the Manchurian Incident of 1931-1932. At the end of his term as Prime Minister, Shidehara ran and served as a member of the Lower House of the Diet, where he held the post of Speaker until his death.

14. Japanese scholarship, in its examination of the origins of Article IX, has tended to view it as a kind of horse trade, the renunciation of war in exchange for the preservation of the Emperor. But the Japanese were hardly in a position to bargain, and MacArthur had probably already decided to preserve the Emperor as a constitutional monarch in the interest of social stability and in order to lend his name to Occupation reforms, despite some protests from Washington and other allies. For a sample of the Japanese view, see Makato Momoi, "Basic Trends in Japanese Security Policies," The Foreign Policy of Modern Japan, ed. by Robert A. Scalapino (Berkeley: University of California Press, 1977), pp. 341-342.

15. Pyle, pp. 158-159.

16. "Statement on the Japanese Draft Constitution (March 6, 1946)," FRUS, 1946: The Far East, pp. 132-133.

17. Leading works of the "revisionist school," which for all the controversy it has generated, has had only the temerity to suggest the importance of continuity in Japanese politics; and perhaps more threateningly, that Japan, despite its American crafted Constitution, is not a society whose fundamental political ideas rest upon notions of western Liberalism. Seminal revisionist works include Chalmers Johnson, MITI and the Japanese Miracle: The Growth of Industrial Policy, 1925-1975 (Stanford: Stanford University Press, 1982); and John W. Dower, Empire and Aftermath: Yoshida Shigeru and the Japanese Experience, 1878-1954 (Cambridge: Harvard University Press, 1988). 


\section{CHAPTER III}

\section{THE EARLY PEACE}

On March 17, 1947, General MacArthur called a press conference at the Dai-Ichi Hotel. What he said took the correspondents that he had assembled by surprise. "The time has now approached," he intoned, "that we must talk peace with Japan."1

The announcement was apparently the General's own initiative, the product of mounting irritation with Washington's quibbles and bureaucratic equivocation, and influenced, possibly, by his own as yet undeclared presidential ambitions. At the end of February 1947, MacArthur had expressed the view that the occupation was reaching a point of diminishing returns in a private Tokyo meeting attended by Interior Secretary Julius Krug and a number of visiting Congressmen: the Constitution, which embodied the principles of demilitarization and political reform had been approved by the Diet and would go into effect in May, and any prolongation of the presence of U.S. troops could stir the kinds of resentments which might jeopardize what had already been achieved. In the meanwhile Japan was becoming an increasingly burdensome drain on the American taxpayer, and only a peace treaty could end the military blockade of international trade which would in turn spur the recovery of the Japanese economy. In case his message had not gotten through, MacArthur then dispatched political advisor George Atcheson 
to further impress upon Washington the urgent need to conclude a liberal and generous treaty as soon as possible. ${ }^{2}$

The problems of the Japanese economy were much on the General's mind. The Occupation had proven disastrous in its management of the economy, and much of its failure to revive can be traced to uncertainties created by Occupation policy on reparations, purges of business executives, and plans to dismember the Zaibatsu combines; objectives which had recently come under severe criticism in the U.S. media. ${ }^{3}$ Industrial production was less than fifteen percent of what it had been in 1941, and during the two previous winters the population had faced the grim prospect of starvation, only remedied by massive provisions from U.S. military stores. George Atcheson clearly recognized the critical link between politics and the economy as early as January of 1946: "political development depends upon solution of the problems of food, shelter, and clothing," he warned, "experience in the practice of democracy are impeded by the preoccupation of the people with economic distress. Left unresolved, these problems may encourage extremism of the types we do not desire."4 By the spring of 1946, rioting and disorder directed at the newly elected but conservative Yoshida Government caused MacArthur to weigh in with a warning of his own, to combat "the growing tendency toward mass violence and physical processes of intimidation, under organized leadership," and cautioned that such tendencies, "present a grave menace to the future development of Japan."5 
On January 31, 1947, only six weeks before MacArthur's press conference, the SCAP was forced to personally intervene to forbid a massive general strike which would have almost certainly crippled the feeble economy and toppled the government. The strike movement had been led by Communists and left-wing Socialists of the Government Workers Union. But the Japanese labor unions had shown that they were capable of wreaking havoc, and the Communists had emerged, at the very least, as a well organized and influential force in Japan's domestic politics. Embarrassingly, they had come to the fore with SCAP's blessing, after the American lifting of restrictions on political activity after the war. Because of its totalitarian tendencies, SCAP had also dismembered the highly centralized Japanese police, allowing only the formation of local constabularies in its place, and they had proven no match against determined political agitators.

In the April general elections which followed, the conservative Yoshida cabinet was replaced by a Socialist coalition, largely because of its failure to address the inflation which was dangerously eroding an already marginal standard of living. Lurking social and economic chaos lent MacArthur's call a touch of urgency: an early peace might stabilize the situation, but it might also allow the SCAP to avoid the repercussions should the Occupation go terribly awry.

Back in Washington, where difficulties in Japan were far from the most pressing of matters, the timing of the General's peace initiative was a source of official consternation. Only five days before the announcement, President Truman, on March 12, had stood before a joint session of Congress to deliver what has come 
to be known as "the Truman Doctrine," a declaration on the part of the United States of its determination to come to the assistance of "free peoples who are resisting attempted subjugation by armed minorities or outside pressures." Though originally applied to Greece and Turkey, its commitment and its logic were open ended, and would soon be applied, in the form of Marshall aid, to the economically ravaged and politically vulnerable societies of western Europe. Although the Soviet Union had not been mentioned in the President's address, it nevertheless signified the crystallization of a fundamental reevaluation of U.S. foreign policy that had been in progress since the end of the war: "At the present moment in world history," Truman somberly observed, "nearly every nation must choose between alternative ways of life."6 The cold war had been declared in earnest.

The vast implications of Truman's pronouncement had been as yet undigested by the greater portion of Washington's labyrinthine foreign policy bureaucracies, not excluding those whose responsibilities included Japanese and Pacific affairs, when MacArthur's March 17 statement exploded in their midst, revealing an appalling, but not particularly surprising, lack of coherence and coordination. The next day, Under Secretary of State Dean Acheson assumed the duty of providing the State Department's official rejoinder. At his own press conference, Acheson replied that "interested divisions" at State had been engaged "for some time" with preparatory work on a peace treaty, but as yet no working draft had been finalized. ${ }^{7}$ 
In reality, at least three different drafts were in preparation, but the priorities on the project were low; the task having been relegated to the Japan scholar Hugh Borton, who now bore the title Special Assistant to the Director of the Office of Far Eastern Affairs. All embodied, to a greater or lesser degree, terms which could only be construed as punitive in the extreme: severe reparations, restriction on importation of raw materials for twenty-five years, and an international commission of inspection to report of any infractions were only a few of the provisions. ${ }^{8}$ No thought had been lavished as to Japan's future security, even though the country was to be denied any forces more threatening than police and coast guard units. The drafts revealed how little the thinking of the Far East division had evolved since 1945; Japan was still the nemesis of the Pacific, and any peace agreement would work to accommodate the desires of China and the Soviet Union.

The drafts were anathema to MacArthur, the very antithesis of the lenient terms he envisaged. In a long memorandum, the SCAP harshly critiqued State's proposals, calling them "imperialistic" as well as "unrealistic." The General vigorously attacked what he took rightly to be the fundamental assumptions underlying the proposed Treaty's terms, that following its signing "a military occupation of Japan should continue, as should existing control machinery in slightly modified form," noting sourly that "the shadow of foreign bayonets is not conducive to rapid democratic growth." But while he urged that any treaty "avoid punitive or arbitrary and complex provisions," he also believed that guarantees of fundamental rights might need to be overseen by the United Nations "for at least a generation." 
The United Nations also figured prominently in the most grandiose component of the General's blueprint for post-treaty Japan, a concept soon ranked amongst MacArthur's more notorious idees fixes, and one which would serve to increasingly alienate the American Caesar from Washington planners and their own evolving schemes. In his own inimitable rhetoric, MacArthur wanted State to know at the outset that if they had not deigned to ponder the prospects of Japan's future security, he, the Father of Article IX, had:

There is here a challenge which all other nations must accept if they would foster and preserve the peace - a challenge to the moral strength of all men and nations of good will, which must firmly be met if physical force is ever to yield to moral force in the settlement of disputes involving men and nations and continents. It is therefore incumbent that the Allied Nations for their part, in the spirit of this constitutional provision, undertake to guarantee the neutrality of Japan, with the view to the transfer of such undertaking to the stewardship of the United Nations, where the responsibility properly should rest. ${ }^{10}$

MacArthur's very public call for a peace treaty with Japan in the spring of 1947 had embarrassed already harried Washington officials, occupied at the time with other, and in their view more pressing matters - stalemate in Germany, aid to Greece and Turkey, the fabrication of the Marshall Plan - and operating in a world and policy environment, in the words of Dean Acheson, "wholly novel within the experience of those who had to deal with it."11 The lack of consideration was matched by the continued dearth of coordination within the State Department, as well as between State and War (whose own opaque statements were largely confined, at the time, to securing continued access to the Ryukyus), while senior officials were conspicuous in the process by their absence. But MacArthur's immense prestige insured that his 
words would create expectations in their wake amongst a cost-conscious Congress, an anxious public, and not least, among the Japanese themselves. On July 11 th, in an atmosphere of great confusion, elements within the State Department, perhaps obliged by MacArthur's remarks, issued invitations to the eleven member countries of the Far Eastern Commission (the Allied body which sat in Washington, and to which the SCAP was, in theory, responsible) to attend a preliminary draft treaty conference. The refusal of the Soviet Union and China to attend on procedural grounds scuttled the conference (both nations desired veto power over any proposal). Had it gone through, Department officials were prepared to offer the same harshly punitive measures which MacArthur had already rejected months before, with the Occupation brought to a quick conclusion and a politically unstable and economically burdened Japan left to fend for itself. ${ }^{12}$

In light of the recently enunciated Truman Doctrine, the utter mystery as to how such a disastrous, from the U.S. perspective, set of events had nearly come to pass remains somewhat inexplicable. In Under Secretary Acheson's major policy address of May 8th, a preview of the Marshall Plan, he portrayed Germany and Japan as "the workshops" of Europe and Asia, to be reconstructed as rapidly as possible, with or without Soviet approval or participation. Certainly, one would think, the fate of Japan would merit the same concern as that of Turkey. The incident reveal the dangers of a ship of state without a captain. For two years, as high ranking officials in Washington busied themselves reinventing U.S. foreign policy in Europe, policy for Japan had all but been handed over to the care of SCAP 
and General MacArthur. Unwittingly cued by the General, bureaucratic backwaters of the State Department then put their outmoded plans into motion. ${ }^{13}$

The near debacle caused others to take notice. George Kennan, director of the Policy Planning Staff at the State Department, having just completed work on the Marshall Plan, looked up from his desk to confess, in the summer of 1947, that the then current situation in Japan filled him with "amazement and concern."14 The new question that had to be answered had become brutally obvious: how was Japan, stripped of its defenses and its economy in shambles, to provide for its own security, to protect itself from communist subversion and intimidation? That question had also alarmed the very people whose fate was being so cavalierly decided. MacArthur's call for a treaty had concentrated the minds of the Japanese leadership wonderfully. It was a dilemma which Japanese leaders had begun to ponder in earnest.

\section{THE PRIME MINISTER AND THE JAPANESE PAST}

Yoshida Shigeru had served in the Japanese Foreign Ministry his entire adult life, since 1906, where early on he garnered the reputation of being an "impertinent fellow," a very un-Japanese thing for a young man to be. ${ }^{15}$ In 1930 , he served as the vice Foreign Minister to Foreign Minister Shidehara, and despite personal misgivings (Yoshida favored a hard line in China), supported the Government's controversial position on naval armaments at the London Conference, a decision which earned him the distrust of the military and their supporters. Yoshida 
reciprocated the sentiment, believing that many members of the armed forces were secretly communists, an idiosyncratic, but not unique notion, and one with later repercussions. His convictions earned him a brief period of imprisonment near the end of the Pacific War. ${ }^{16}$

But misfortune had a way of turning to Yoshida's advantage. Despite his identification with the pre-war "reactionaries" in the eyes of the Occupation authorities, his incarceration won him their tolerance, if not approval. Though defeat had severed Japan's official relations with the wider world, Yoshida, a former bureaucrat turned politician, served the Shidehara Cabinet as Foreign Minister, heading the Central Liaison Agency, the main intermediary between SCAP and the Japanese Government. The pre-war Foreign Ministry in all but name, under Yoshida's direction the agency began a number of prolonged and comprehensive studies to examine future Japanese options on territorial and strategic issues. ${ }^{17}$ In the aftermath of the April 1946 elections, when one of Yoshida's rivals was purged on the eve of assuming the premiership, Yoshida stepped in to the Prime Minister's office, where he served concurrently as his own Foreign Minister, a practice he would continue until the end of the occupation.

By February 1947, as rumor spread that MacArthur was pressing the desirability of an early peace with visiting Washington dignitaries, Yoshida quietly summoned officials from the Central Liaison Agency to direct discrete and informal inquiries at Occupation authorities, particularly at the office of Political Advisor George Atcheson, on peace and security issues. ${ }^{18}$ Yoshida was well aware that he 
and his government were operating at an extreme disadvantage in attempting to enter in to any diplomatic dialogue. His government did not enjoy much esteem within SCAP, which tended to view his administration as inept when it was not obstructionist; while Yoshida, for his part, did not always prudently conceal his exasperation with Occupation "reformers" whom he blamed, rightly or wrongly, for fomenting chaos in the economy, and in the streets. And lacking any representation in Washington, his government had no alternative but to rely on a fickle SCAP as intermediary, for Japanese officials could never be certain that their views would be passed along, nor whether the policies propounded by Occupation authorities originated across the Pacific or in SCAP's Tokyo headquarters.

But diplomacy was the Prime Minister's bailiwick, his area of greatest expertise, and he was firmly convinced that history had provided previous examples of nations that had lost the war only to win the peace. The bureaucrats of the Central Liaison Agency were able, highly skilled men, tremendously motivated, and possessed of great reserves of institutional memory, an invaluable asset in dealing with the inscrutable foreigners. As the Japanese were to prove adept at exploiting the rivalries within SCAP, they were just as quick to perceive the growing differences between SCAP and Washington, and ultimately, between Washington and Moscow. To turn the changing political and strategic firmament to Japan's advantage, to restore to Japan its sovereignty in the shortest time and on the best possible terms, these were the not inconsiderable tasks to which Yoshida would devote much of his abundant energies. 
Until 1947, those terms did not look very promising. Under a punitive peace of enforced demilitarization, the policy of the Japanese Government was to seek security guarantees from the U.S., Great Britain, China and the U.S.S.R. to respect Japan's permanent neutrality, although the Japanese entertained anxious doubts over whether such guarantees could be secured, and even if granted, whether they held out much prospect of being respected. Yoshida, among others, was broodingly aware that the Soviet Union's declaration of war had been carried out despite the 1941 neutrality pact then still in effect. ${ }^{19}$

The growing rift between Washington and the Soviets, the deepening of the Chinese civil war, and MacArthur's peace treaty announcement all suggested an altered climate and new opportunities. Yoshida sensed "the atmosphere was now favorable for the opening of private and unofficial talks," and discovered Atcheson at least willing to note Japanese sentiments. Still, Atcheson asserted privately to a gathering of Liaison officials that "the question of Japanese security policy has not yet become a realistic issue. But it seems to me that, when it does, the United States may suggest that Japan request a security guarantee from the United Nations." 20 When he spoke it was with the unambiguous voice of General MacArthur.

Yoshida and his bureaucrats did not know at the time the perilous extent of the foreign policy turmoil then besetting Washington, but from Atcheson's vague, and in their view, rather unrealistic responses, they could at the very least discern that "the United States Government did not have a clear conception of a post-treaty security arrangement for Japan." A touch of desperation is evident in the efforts of 
perturbed Japanese negotiators to sweep the minds of SCAP officialdom free of fantasies. Tactfully, but insistently, they wished to impress upon Atcheson, as Yoshida recalled one of their meetings, that:

For Japan, the security issue is an extremely realistic and serious problem. It is not clear that the United Nations peace-keeping machinery will materialize. In any case, it is not now complete and there seems to be no way for Japan to provide for defense against foreign invasion and to protect her independence, except by an alliance with a third power. ${ }^{21}$

Unmistakably, Yoshida's reference to a "third power" could only have meant the United States.

It was a suggestion which was not particularly welcome to SCAP officials; General MacArthur was unamused. When the contents of these discussions were leaked to the newspapers by Japanese diplomats, the press treated the matter not as it was -- an example of wishful thinking in the Foreign Office -- but as a transformation of U.S. policy mouthed by the SCAP himself. MacArthur quickly squelched the notion after a May 7th meeting with the Emperor: "I have not seen press dispatches reported to allege my assurance that the United States would undertake the future defense of Japan, but if such statements have been attributed to me, their absurdity is so evident as to warrant no serious comment." ${ }^{22}$ Needless to say, the contents of these suggestions, coming as they had from the soon to be departing Yoshida Government (having been defeated in the recently concluded April elections), were not forwarded to Washington.

Yet the incoming coalition Cabinet, headed by the Socialist Prime Minister Katayama Tetsu, did not bring any alteration in the positions already taken by 
Yoshida and the Foreign Ministry bureaucrats; if anything, the new government represented a redoubling of efforts. Rather astonishingly, when considered in light of later developments, the Socialists seemingly had no considered opinions on Japan's security, and the new Foreign Minister Ashida Hitoshi, was, though a political rival of Yoshida, cut of the same conservative cloth, a former Foreign Ministry official turned party politician. But the connections between the two men ran even deeper than the above coincidences might suggest.

They shared a similar outlook, one tinged with nostalgia, but firmly rooted in historical precedent and a long and somber calculation of geographic and strategic realities. As young men they had begun their respective careers at a time when the Anglo-Japanese Alliance (1902-1922) was the great fact of Japan's international existence and the great achievement of Japan's modern diplomacy, a veritable monument to the wisdom of Meiji. To the diplomats of Yoshida's generation the alliance was the lost symbol of a diplomatic golden age.

The achievement had been real enough, both as an emblem of Japan's new found international status on par with the European colonial powers, and as an answer to its most pressing strategic dilemma, the defense of its Korean and Manchurian frontier. Should one of the parties, under the terms of the alliance, become involved in hostilities with a rival power in East Asia (an important geographical limitation), the other pledged to come to its assistance, but only when and if another power joined forces with the original adversary. The alliance was pointedly directed at curbing the territorial ambitions of imperial Russia, and its 
existence was credited with provoking the Russo-Japanese War of 1905, and making a Japanese victory possible. But beneath the literal stipulations of the alliance lay a sort of gentlemen's understanding, more cherished by Japanese leaders than by their British counterparts. It was essentially this: the power of the British fleet would serve the creation of a Japanese empire on the mainland of Asia as long as the rights and commercial privileges of an overstretched Britain were respected in China. To Yoshida and others of his ilk, the alliance had come to represent the measured and prudent attainment of legitimate imperial aspirations, an era in direct contrast to the one that followed its abandonment, in which the short-sighted corruption of party politicians and the zealotry of military fanatics brought ruin in their train.

Though Japan's empire was gone, and its frontiers had shrunken to the confines of the four main islands, the desire for a "third power alliance" was thus not without precedent, nor piquant analogy. From the perspective of the Foreign Ministry, United States naval power had merely superseded that of Great Britain, and Soviet designs, if somewhat unknown, were hardly likely to prove more benign than those of its imperial sire. Soviet forces remained poised upon the southern Kurile Islands, seized at the end of the Pacific War, and only a handful of miles from the northern Hokkaido coast. It was then with some perplexity and consternation to Japanese officials to encounter a SCAP so resistant to their suggestions, since what they heard coming from Washington (most notably Under Secretary Acheson's May address in Cleveland Mississippi, which had occurred as the Katayama Cabinet was 
being formed), had been interpreted as a desire to conclude a peace without the Soviets, if necessary. Seizing the glimmer of an opportunity to avoid a harsh settlement, Foreign Minister Ashida, like Yoshida before him (and with whom he continued to confer regularly), ${ }^{23}$ wanted those in Washington to know that Japan was willing to consider the idea of a "separate peace" if the alternative was the kind of stalemate which had blocked progress on a German peace treaty. The Soviet refusal to attend the preliminary conference called by the State Department in July only served to reinforce these sentiments.

Mounting frustration, and a growing suspicion that Japanese suggestions had not been communicated to Washington led Ashida to abandon informal discussions in June 1947, to begin work on a substantive memorandum setting forth the government's posture on peace and security issues. On June 28 , after conferring with the Prime Minister, Ashida submitted the document to Political Advisor Atcheson and General Courtney Whitney, head of Government Section. ${ }^{24}$ In his memoirs, Yoshida hinted at the gist of the memo's contents:

...it was thought at first that if the Allied forces were going to remain in Japan after the signing of a peace treaty the purpose would be to ensure that the term of the treaty would be carried out, much in the manner of what occurred in Germany after the signing of the Versailles Treaty....As U.S.- Soviet relations became ever more strained, however, we could sense that the American view was changing to that of the need to guarantee Japanese security as part of world security. Our own ideas began to tend in the direction of having the United States reinforce our defenses, rather than relying upon what was then the still problematical organization of the United Nations to assist us in the event of need. ${ }^{25}$ 
The next day Whitney returned the memo, attached to one of his own, firmly indicating that the time was yet unfeasible for more formal discussion on the issues raised by the document. ${ }^{26}$

After the failure of the July conference to materialize, SCAP's position may have softened; but returning to Washington in mid-August, Mr. Atcheson met an untimely end while enroute in an airplane over the Pacific, the Ashida memorandum apparently among his effects. ${ }^{27}$ Personal tragedy brought an end to these preliminary efforts to overcome the surprisingly formidable barriers which prevented the views of one government to be made known to another.

Disheartened but not defeated, for the diligent Japanese it would not be their last attempt; but perhaps they had only been premature. Though attitudes in official Washington were slowly changing as cold war tensions in Europe mounted, over a year would elapse before the policy of the United States reached the almost identical conclusions that their unknown Japanese counterparts had advocated all along.

\section{POLICY PLANNING}

Within the confines of the Division of Far Eastern Affairs of the State Department, Mr. Borton and his colleagues continued in their indefatigable efforts to produce a Japanese draft treaty. Their revised drafts of August 1947, and an even later product produced in January 1948, betrayed a still tenacious adherence to the principles of Potsdam. To prevent the resurrection of Japan's military machine 
remained the unyielding objective, and close cooperation with all the wartime allies was how it was to be achieved, the recent Soviet refusal to attend the July's preliminary peace conference notwithstanding.

MacArthur continued to voice his objections. Commenting on the August draft in a memo to Secretary of State Marshall, the General labeled numerous provisions as "highly questionable." He highlighted for special emphasis the retention of the Ryukyus by Japan (U.S. control being "absolutely essential" and any failure on this regard "might prove militarily disastrous"); and the post-treaty utilization of Allied forces on Japanese soil (such an arrangement could "provide a possible stepping stone for Russia or some other objectionable foreign power to acquire a military foothold"). In concluding, MacArthur emphasized that the contemplated draft was based on the assumption that all parties at war with Japan would participate in its ratification: "Should any nation, such as Russia, abstain from the peace negotiations...the situation thereby created would necessitate consideration... of the problem, especially those involving withdrawal of the occupation forces, from an entirely different point of view. ${ }^{28}$ By this time, however, Secretary Marshall had already received far more dire appraisals of the state of U.S. policy towards Japan much closer to home.

That policy began its torturous metamorphosis in earnest the day the August draft treaty crossed the desk of John P. Davies, Jr., of the Policy Planning Staff, who quickly forwarded it, and the following memo, to the Director of the Staff, George Kennan. On August 11, Davies wrote: 
It would seem that a peace settlement for Japan proposed by the American Government should further American aims in Japan and the Pacific area. The central American objective in this respect is taken to be a stable Japan, integrated into the Pacific economy, friendly to the U.S. and, in case of need, a ready and dependable Ally of the U.S.

Davies had crossed the conceptual Rubicon: American interests, rather than a chimerical harmony amongst the wartime Allies, should henceforward guide U.S. policy. The notion, implicit perhaps since May, was now explicit; no longer a vanquished foe, Japan should be considered as a potential ally of the United States. Davies continued:

Rather than assuring a furtherance of our central objective, the Draft Treaty of Peace for Japan appears to be preoccupied with drastic disarmament and democratization under continuing international supervision, including the U.S.S.R. But demilitarization is no longer a serious problem in the case of Japan. Even if it so desired, Japan could not in the foreseeable future resurrect itself as a first-class military power. It can only gravitate into the orbit of one or another of the super powers. ${ }^{29}$

The global implications of the Truman Doctrine had just been applied in spades; the cold war had reached the Pacific and Japan was the strategic prize.

Kennan, in turn passed on the Davies memo, and one of his own to Robert Lovett, who at the end of June had replaced Dean Acheson as Under Secretary. His own unhappiness and misgivings with the draft were clear: "So far as I know, we have not yet formulated with any degree of concreteness our objectives with respect to Japan....[and] this draft does not seem to be related to any realistic pattern of such objectives that we can conceive of here." Kennan, without endorsing Davies' conclusions, added that he thought it would be "highly dangerous" for the U.S. to 
initiate peace discussions until U.S. desires could be "systematically thrashed out" at "a high level" with treaty provisions then related accordingly. Lovett concurred, describing the draft as "wholly inadequate" and assuring Kennan that the views of PPS were being "passed along." ${ }^{10}$

The Pentagon too, had its own set of parochial concerns that it wished the draft treaty writers to address. Commenting informally to the Borton group, Rear Admiral E.T. Woolridge pointed out that the draft contradicted a desire on the part of the Joint Chiefs to retain the Ryukyu Islands, a wish expressed to President Truman as early as October 1946. The Navy, in addition, made it known that it wanted base rights in Yokosuka, at the entrance to Tokyo Bay, and adjoining air fields "to provide protection." Finally, Admiral Woolridge, while noting Japan's undefended state under the articles for demilitarization and disarmament, laconically advised that "under existing world conditions" the occupation should continue until such time as the U.N. was prepared to assume those duties. ${ }^{31}$

Seemingly undismayed by the negative reviews garnered by their efforts, like all good bureaucrats, the treaty drafters continued to assert the rightness of their cause and righteous resentment over the unwanted intrusions. "The crying need of the moment," insisted one plaint delivered to the desk of the Deputy Director of Far Eastern Affairs, "is believed to be the assertion of leadership by the United States in the Pacific." A peace settlement with Japan, even a bad one presumably, would prove "the ideal springboard" for just such an assertion, while delay in using the "springboard" would fatally undermine any "program of leadership."32 But such 
cries fell on deaf ears. Except for matters of routine, the formulation of United States policy toward Japan had been placed before the purview of the Policy Planning Staff.

\section{THE ASHIDA NOTES}

Before the end of the year, Japanese officials would make one final attempt to communicate their ideas on peace and security issues directly to Washington. MacArthur's growing estrangement from Washington, and his highhanded dismissal of earlier Japanese views, led Foreign Minister Ashida to concede the hopelessness of any message finding its way from SCAP's Tokyo headquarters. Hence, he would attempt another avenue of egress, concocting a proverbial end run around the byzantine bureaucracy which surrounded the General.

On September 10, Suzuki Tadakatsu, head of the Central Liaison Agency, personally gave over a memorandum prepared in his name to the care of General Robert L. Eichelberger, commander of the Eighth Army. The Japanese had made a considered choice when they selected their messenger: Eichelberger, headquartered in Yokohama, had a goodly measure of autonomy within SCAP, enjoyed his own channels of communication with the War Department, and had been receptive towards both Japanese leaders and those in the U.S. who had begun to question MacArthur's handling of the occupation. Most importantly, General Eichelberger was soon to depart for Washington on an extended home leave. ${ }^{33}$ 
The memo, originally written in English, had been a collaborative effort between Minister Ashida and the Socialist Chief Cabinet Secretary, Nishio Suehiro, as well Suzuki and the bureaucrats of the Liaison Agency; apparently former Prime Minister Yoshida was kept fully appraised of its contents. The completed document was a far more explicit statement of Japanese security concerns than any previously expressed to a U.S. official, and represented the rapid progression of Japanese Government thinking that had taken place since the earlier rebuffs by SCAP of May and June. Prime Minister Yoshida later revealed its contents:

Its purport was that, while Japan was in a position to deal with internal disturbances without outside aid, the best means of safeguarding her independence in the present condition of international stress was for Japan to enter into a special pact with the United States against external aggression by a third country, while at the same time reinforcing her own land and sea forces, and that, further, it was thought that, so long as the United Nations was not yet capable of fully enforcing the terms of its charter, the Japanese people desired the security of their country to be guaranteed by the United States. ${ }^{34}$

In the Japanese version of his memoirs, Yoshida was even more candid: "This document was based on the idea that the United States would maintain armed forces in the areas adjacent to Japan, and that Japan would maintain bases within the country to be made available for use by the United States forces in an emergency." ${ }^{135}$ Yoshida adds, "There did not seem to me to be any other possible policy, and after I had resumed the position of Prime Minister again in October 1948 it was adopted by my Cabinet without change. ${ }^{136}$

The memo became a touchstone of Japanese foreign policy, an honorable compromise, or so it seemed to its creators, between Japan's desire for autonomy 
and a recognition of its weakness. It was also a symbol of a remarkable, if somewhat accidental, domestic political consensus, one that was not fated to endure, but that while it existed ran the narrow gauntlet of contradictory necessity: the need to find a military ally in the United States but without unduly antagonizing Japan's neighbors. The consensus and the compromise were predicated upon the major principles so clearly delineated, principles which became the basis for later negotiations with the United States: a need to rebuild police power sufficient to cope with its own internal unrest, and; a program of limited rearmament in exchange for a security guarantee, but with no provision for the permanent stationing of U.S. troops on Japanese soil.

Whether such arrangements could have ever been found acceptable within the increasingly conspiratorial and Manichean world view of the Washington policy establishment, it is possible only to speculate. It is nonetheless almost certain that the views of the Japanese should have proven of immense interest to at least some Washington officials in late 1947. It is thus astonishing to discover that in a meeting with Suzuki to discuss the reaction to the Japanese proposals upon his return to Japan, General Eichelberger confided that the U.S. was not yet ready to conclude treaties with Germany and Japan without Soviet participation. ${ }^{37}$ It is even more surprising that later policy makers make no mention of the proposals, indeed seem entirely ignorant of Japanese Government views and intentions.

For Foreign Minister Ashida, this second rebuff must have been both puzzling and immensely troubling. U.S. inclinations towards Japan were as opaque 
as ever. In exchange for a quick and lenient peace, the Japanese were prepared to ally their nation with the United States in the deepening cold war. This offer had seemingly been rejected. General Eichelberger would have had ample reasons for not passing along the entrusted memo, ranging from the possible inappropriateness of his serving as a conduit for the Japanese Government, to a failure to comprehend its political significance. On the other hand, the timing may simply have been off. The Pentagon to which Eichelberger returned to was in the midst of a massive bureaucratic reorganization, due to the passage of the National Security Act in July; while over at State, top secret meetings were in progress as members of the Policy Planning Staff conducted an intense reexamination of the U.S.'s Japan policy. Either may have made a more considered response than the one Eichelberger supplied impossible.

Still, the failure to communicate, for whatever reason, was unfortunate, an opportunity missed. Because for all the permutations of U.S. policy to come, distrust remained the constant element, the most enduring and invidious legacy of the war. The Japanese leadership had proposed, they thought, a relationship, if not of equals, at least of sovereigns, one that accommodated Japanese desires while acknowledging the imperatives of the victors. In the minds of many in Washington (not all, to be sure, but among those whose views would prevail), to refashion the enemy as ally, Japan would need to be enticed and bullied, before being rigidly clasped to the U.S. bosom in an uncomfortable, suffocating embrace. 
PPS $/ 10$

By mid-October, after eight weeks of study and consultations with the Far Eastern Office, the Pentagon, and outside experts such as former Ambassador to Japan Joseph Grew, George Kennan presented the conclusions of the policy review to Secretary Marshall. Kennan nonetheless, cautioned as to their tentative nature, lamenting "that in regard to several of the most important issues involved we do not have before us here in Washington the facts which would enable us to make firm and sound judgments on some of the most important points at issue." Kennan believed it essential "that some high official of this Department" proceed to Tokyo in an attempt to penetrate the turbid lair of General MacArthur and gather a further sounding of his views. Marshall concurred, and in the course of a number of ensuing meetings, Kennan himself reluctantly inherited the assignment. ${ }^{38}$

Whatever their limitations, the recommendations of the Policy Planning review, labeled PPS/10, were nonetheless far-reaching in at least one respect. While recognizing that the occupation was nearing the end of its effectiveness, the report's central conclusion warned of "great risks in an early relinquishment of Allied control over Japan." There was no guarantee, and no evidence to support the idea that a newly sovereign Japan would be a politically or economically stable society. Such a situation bred an ominous certainty, "Moscow-controlled communists will then make an intensive effort to penetrate and dominate Japanese political life." ${ }^{139}$ 
Voiced perhaps, in somewhat bombastic terms, the threat was real enough. Yet in the face of these threats the report offered contradictory or ambiguous prescriptions. The U.S. should proceed, albeit cautiously, with peace negotiations. Soviet inclusion in these talks was desirable, but if impossible, Soviet exclusion should stem from substantive, rather than procedural issues. If a treaty could not be negotiated, the U.S. could gradually modify the more onerous aspects of the occupation regime, but whether this should be done concurrently in the interest of Japan's economic stability, the report only notes the existence of highly conflicting opinion. $^{40}$

The same spirit of measured qualifications pervaded discussion of security issues. While the report strongly advised that the U.S. "make plain our will and determination to prevent any other military power from establishing itself in the Japanese home islands" as a fundamental principle of American security, any treaty would also uphold the principle of complete Japanese disarmament (including industrial potential) under a regime of international inspection, exempting only police and coast guard units. "Admittedly," the report followed, "this leaves the Japanese without means of self-defense against foreign aggression." This was unfortunate, but unavoidable. Japanese external security would need to rest upon the near proximity of U.S. forces, presumably stationed in Okinawa. As to the issue of U.S. bases on Japanese soil, "We have no evidence that facilities for land forces or for air forces alone...would serve any useful purpose." The Navy's desire for facilities at Yokosuka received acknowledgment but not approval, the report 
guardedly advising a decision would involve "far-reaching political considerations, both internal Japanese and international." A more definitive position was impracticable: "From the standpoint of U.S. security, the Staff does not consider this moment propitious for a final decision on this subject. ${ }^{\text {"41 }}$

The evasive, uncertain tone of the document can be directly traced to its transitional character, a jumble of old policy commitments leavened by future concerns and issues. Far from a clean break, the review by the Policy Staff had not fundamentally resolved anything, and by year's end, U.S. policy was still a muddle, as Dean Acheson impatiently recognized. "We need to establish [the] basic pattern [of] our policy and answer fundamental questions," he worried, before the U.S. could make any further diplomatic moves towards a peace treaty, while the momentous yet delicate issue of Soviet participation loomed. ${ }^{42}$ Those answers would need to wait upon Kennan's Tokyo consultations with General MacArthur, as Acheson was aware. Yet, if the review initiated by PPS had failed to define U.S. policy towards Japan, it had at least uncovered some dangerous discrepancies. But it had accomplished more than that: it had begun a process of condensation and reevaluation of as yet unknowable consequence, but one to be definitively influenced by the edgy concourse of events. 


\section{NOTES}

1. Martin Weinstein, Japan's Postwar Defense Policy, 1947-1968 (New York: Columbia University Press, 1971), p. 14.

2. Ibid., pp. 14-15.

3. Newsweek had been particularly harsh on Occupation administration of the Japanese economy in articles published on January 27th and February 10th, 1947, and MacArthur, in fine paranoid style, confided privately to a friend that the pieces were part of "the campaign which is being so assiduously pressed in the east to discredit me." See Howard Schonberger, "The Japan Lobby in American Diplomacy, 1947-1952," Pacific Historical Review, vol. 46, no. 3 (August, 1977), p. 330.

4. "Japanese Democratic Political Situation (January 4, 1946)," FRUS, 1946: The Far East, pp. 87-90.

5. Mark Gayn, "Food Demonstrations and MacArthur's Warning," in Livingston, p. 148.

6. David McCullough, Truman (New York: Simon and Schuster, 1992), pp. 547-548.

7. FRUS, 1947, vol. 6: The Far East, p. 457.

8. Dunn, pp. 58-59.

9. FRUS (March 21, 1947), pp. 454-456.

10. Ibid.

11. McCullough, p. 555.

12. Dunn, pp. 64-66.

13. Even though the conference had collapsed, Congress and the media continued to press for an early treaty to end the cost of the Occupation to tax payers. On August 16, the provincial New York Times editorialized that "No agreement and no moral law requires us to perpetuate a situation which costs us hundreds of millions of dollars yearly," while in the fall both Senator William Howard Taft and the House Armed Services Committee criticized the mounting costs of the Occupation and demanded an early treaty regardless of Soviet participation. See Dunn, p. 69. 
14. Kennan, p. 375.

15. Dower, p. 39.

16. Ibid., pp. $91-93 \&$ pp. 255-272.

17. Weinstein, p. 15; and Dower, p. 373.

18. Yoshida, p. 264.

19. Weinstein, pp. 16-17.

20. Ibid., p. 19; Yoshida, p. 264.

21. Weinstein, p. 20; and in a slightly different version, Yoshida, p. 264.

22. Political Reorientation of Japan, vol. 2, Appendix F: 33, p. 769.

23. Weinstein, p. 22.

24. Ibid.

25. Yoshida, pp. 264-265.

26. Weinstein, p. 22.

27. Ibid.

28. FRUS (September 1, 1947), pp. 512-515.

29. Ibid., pp. 485-486.

30. Ibid., pp. 486-487.

31. Ibid. (August 18, 1947), pp. 495-496.

32. The memo, by Max W. Bishop of the Division of Northeast Asian Affairs, was passed on by the Deputy Director, Mr. Penfield, to Kennan, Charles Bohlen, and General Saltzman, to no great effect. Ibid. (August 14, 1947), pp. 492-494.

33. Weinstein, pp. 24-25; Schonberger, pp. 340-341.

34. Yoshida, p. 265.

35. Quoted in Weinstein, p. 25.

36. Yoshida, op. cit. 
37. Weinstein, p. 25.

38. FRUS (October 14, 1947), pp. 536-537; Kennan, p. 377.

39. FRUS, p. 537 and p. 541.

40. Ibid., pp. 537-543.

41. Ibid., pp. 540-541.

42. Ibid. (December 15, 1947), p. 591. 


\section{CHAPTER IV}

\section{REORIENTATION: THE KENNAN MISSION AND NSC 13/2}

It was a disquieted George Kennan who pondered the fate of his upcoming mission to Japan, scheduled to depart for Tokyo in late February 1948. The prevailing mood of official Washington was grim -- the Soviet inspired coup in Czechoslovakia seemed but the prelude to General Eisenhower's prophecy of "chaos and Communism" in Europe and the Far East ${ }^{1}$-- and his own task hovered with nearly equal menace. MacArthur's antipathy toward the State Department was a matter of record. Secretary Marshall, who spoke from experience, warned Kennan of MacArthur's ego and paranoia; to be wary of his vicious and sycophantic camarilla. Kennan's colleagues in the Far Eastern Division expressed their "unconcealed skepticism" for his prospects, and Marshall showed a "disinclination to become involved." Kennan was, as he realized, "very much on my own," while undertaking a mission which he described, without irony, as "that of an envoy charged with...arranging the establishment of diplomatic relations with a hostile and suspicious foreign government." ${ }^{2}$

Making its own unique contribution to these already inauspicious circumstances was the Department of Defense, which Kennan perceived to be both "alarmed and intrigued" at the prospect of a meeting between the "civilian David" and the "military Goliath". Quick to perceive that its own prerogatives might be at 
stake, the Pentagon used its clout to provide Kennan with a companion, the tactful General Schuyler, to provide an independent account of the mission's doings and progress. While this was occurring, the office of Under Secretary of the Army William Draper, who was to commence his own Tokyo sojourn soon after Kennan's departure, busied itself leaking provocative stories to the press, all designed to ensure Kennan an even cooler reception from an already frosty SCAP. MacArthur (who at the time was deeply immersed in plotting a bid for the Republican Presidential nomination), ${ }^{3}$ when appraised of Kennan's visit, merely growled, "I'll have him briefed until it comes out of his ears." ${ }^{14}$

On March 1, the afternoon of their arrival, Kennan and Schuyler prepared for luncheon with General and Mrs. MacArthur. The men were sleepless, exhausted by the ordeal of their Pacific crossing, and over the course of their repast were treated to a two hour monologue by the General upon his favorite themes: Caesar's occupation of Gaul (the only previous example, prior to his own, of a successful military occupation); the spiritual revolution of the Japanese nation engendered by defeat; their great thirst for democracy and Christianity; the shortsightedness of Washington in underestimating the importance of Asia. During the course of this messianic diatribe, MacArthur, pounding the table and waving a forefinger for emphasis, turned his back to Kennan and addressed his remarks to Schuyler. The performance was a set-piece, delivered on numerous previous occasions to thrall audiences of visiting Congressmen, but it was not wholly without 
insight. MacArthur emphasized his belief that if the occupation were not brought to an early conclusion Japan would end up becoming a satellite of the United States. ${ }^{5}$

After two days of uninformative briefings and determined to be put off no longer, Kennan addressed a brief message to the SCAP, in which he confided that he was under instructions to sound out the General personally on issues of central importance:

Our existing occupational policies are based on the Potsdam Declaration. But the objectives of the Potsdam Declaration were really pertinent only to the immediate post-surrender period. They made provision for the security of the Allies from Japanese aggression. They made no provision for the security of the Japanese islands from aggression, overt or concealed, from outside.

Kennan suggested that the Potsdam objectives, having been achieved, could no longer guide the direction of future policy:

It appears to many of us in Washington that in view of the developing world situation the keynote of occupational policy, from here on out, should lie in the achievement of maximum stability of Japanese society, in order that Japan may best be able to stand on her own feet when the protecting hand is withdrawn.

Kennan offered that this might be best furthered by developing a comprehensive security policy, a program of economic recovery, and a relaxation of occupational controls; carefully adding, "Any comment which the Commander-in-Chief might care to make on the above would be much appreciated."6

The ploy worked. In the course of a long and private audience, MacArthur began by fulminating against the impediments thrown up by the Far Eastern Commission to any reasonable revision of occupation policy (which Kennan later disposed of, by an ingenious suggestion, much to the General's pleasure). ${ }^{7}$ Then 
turning to security issues, MacArthur freely elaborated upon his conception of strategic doctrine in the Pacific. The war had rendered obsolete the old strategic boundaries of the United States along the western continental shores of North and South America; but were now pushed astride the Asian littorals of the western Pacific. "Our fundamental strategic task," he asserted, "was to make sure no serious amphibious force could ever be assembled and dispatched from an Asiatic port."

Okinawa, MacArthur believed, was the vital keystone of this rather grand enterprise for a pair of reasons. Naval and air facilities based on Okinawa could strike at any port on the Asian coast from which hostile forces might feasibly be launched. Secondly, the retention of Okinawa would undo the need for bases in Japan to provide for United States security. MacArthur believed post-treaty bases were unwise in any case, because other Allies might demand the same. ${ }^{9}$

The solicitous Kennan had managed to allay the suspicious General, but much of what he saw on his subsequent travels about Japan outraged the diplomat's sensibilities and confirmed his deepest fears. SCAP was a vast and monstrous parasite sucking the life from a desperate people. Although the Katayama Cabinet had just fallen because of its failed efforts to bring order to the economy, the Japanese government was constructing, at its own expense, 17,000 new units to house occupation personnel, while thousands of Japanese lived homeless in smashed and cratered cities. Most of the nearly 90,000 members of the occupation, Kennan observed with dismay, "were engaged in housekeeping duties," while no provision had been made for Japan's defense in case of attack. ${ }^{10}$ 
Under the name of reform, SCAP's purge was being carried out "with a dogmatic, impersonal vindictiveness, for which there were few examples outside the totalitarian countries themselves." The attitudes espoused for the dismemberment of Japanese corporations "bore...a resemblance to Soviet views about the evils of 'capitalist monopolies."' If MacArthur liked to compare the occupation to Caesar's reign in Gaul, Kennan drew another, less flattering classical analogy, likening the gossip and intrigue surrounding MacArthur to the court of the Byzantine General Belisarius in Italy; and he recoiled from the "monumental imperviousness" shown by SCAP officials to the suffering of the Japanese people, while the Americans "monopolized...everything that smacks of comfort or elegance or luxury."11

Putting aside his personal feelings during a brief tour of the Philippines before returning to Japan, Kennan relayed some of his preliminary impressions to the Secretary of State. But he did not hesitate to confirm that, "Our most immediate and important problem in the western Pacific area is strategic," and that so far as he could learn, "we are operating without any over-all strategic concept for the entire western Pacific area." There were as yet no clear objectives to provide for Japan's post-treaty security, and currently SCAP was unprepared to conduct either ground operations or withdraw its personnel in an emergency. The occupation remained in Japan "principally because we have no international mandate to leave," all the while entrenching itself in Japan in undesirable ways. ${ }^{12}$

Kennan returned to Tokyo for one last conference with MacArthur before departing for Washington. The central topic of conversation was the rearmament of 
Japan. Kennan, Schuyler, and MacArthur were joined by the freshly arrived Army Under Secretary Draper, who began the meeting by indicating to MacArthur that recent trends in Pentagon thinking had begun to consider the creation of a limited defense force for Japan, to be ready by the time of the occupation's withdrawal. A month before, on February 24, Defense Secretary Forrestal had commissioned the Army to commence a study to inquire into "limited military armaments for Germany and Japan."13

MacArthur was "unalterably opposed to any such plan." U.S. efforts in any such undertaking would be a violation of sworn international commitments, and would be viewed as a betrayal of the fundamental principles which had guided the occupation. Even with sizable U.S. assistance, the maintenance of a defense establishment would further burden the Japanese economy; nor would such efforts be likely to produce anything better than "a fifth-rate military power" capable of provoking the Russians and frightening the rest of Asia, but unable to mount a credible defense of the country. MacArthur also warned of a backlash of public opinion, of pacifist sentiments which the occupation had encouraged, of constitutional difficulties, and of potential return to power of a military clique. The Japanese would be extremely reluctant to resurrect their armed forces unless coerced by the United States. "This," he said, "we should not do." He ended by again insisting on the importance of Okinawa for Japan's external defense. ${ }^{14}$ Ironically, Japanese leaders, in nearly identical circumstances, would adopt the very same arguments two short years later. 
Kennan finished and submitted the lengthy report containing his recommendations, labeled PPS 28, soon after his return to Washington. He strongly advised that the United States abandon efforts to negotiate a peace treaty for the time being, but that its eventual form should be brief and non-punitive. In the meantime Japanese society should be prepared for the removal of "the regime of control." This meant SCAP personnel should be trimmed and further efforts at reform should cease. Japanese police forces should be strengthened and centralized under American supervision. ${ }^{15}$ Economic recovery "should be made the prime objective of United States policy in Japan."16 Okinawa should be developed as a major military facility.

Kennan reiterated MacArthur's cherished vision of a completely demilitarized Japan, its neutrality underwritten by international guarantees, but he could not bring himself to agree with it, at least at the time. ${ }^{17}$ MacArthur felt that until such guarantees could be arranged that Allied troops would have to remain in Japan, but did not envisage tremendous difficulties in securing them, even from the Soviet Union. MacArthur, Kennan wrote incredulously, "is content to see Japanese security rest on such a demilitarization treaty, to which the Russians would be party. He believes that when the Russians put their signature to something clear and explicit, they will remain faithful to their word."18 And to Kennan, MacArthur had dismissed the notion of Communist subversion, claiming that the Japanese people, buttressed perhaps by their new-found faith in Christ, would reject it. 
Kennan's analysis was far less sanguine. An expert on Soviet affairs and political psychology, he gravely counseled that Soviet pledges to respect Japanese neutrality could not be trusted "unless Russia were considerably weaker and more constrained in her immediate aims and policies than is the case today." If Kennan erred in his analysis, it arose because he saw Soviet intentions in Japan too much in the light of events in east Europe. By way of analogy, Kennan discerned a nation ripe for political subversion: the Communists were not engaged in a political popularity contest, it was more a matter of penetrating and controlling the vital positions of an unstable society. "At present," he adduced, "it looks to me as though Japanese society were decidedly vulnerable to such attacks."19

PPS 28 did not envisage or recommend a Japan closely allied to the United States. As to the retention of bases in the post-occupation period, it was not discussed in any detail, Kennan briefly noting that he thought the idea "psychologically unsound" for Allied occupation forces to remain after a peace treaty had gone into effect, and other possibilities were not entertained. There was not the hint of a suggestion that the United States should in any way "guarantee" Japan's security. Kennan's conclusions were nonetheless startlingly direct:

World conditions are now in a state of extreme flux. Plainly, we are not going to have a treaty, or even proceed to the negotiations of a treaty, for some time. We do not know today what the situation of Russia will be when the time comes to negotiate the treaty. Yet this will be the decisive point. If Russia still presents the same sort of threat to world security that she presents today, then I see only two alternatives: either we must not have the treaty at all and retain allied troops in Japan or we must permit Japan to re-arm to the extent that it would no longer constitute an open invitation to military aggression. $^{20}$ 
Kennan had left his superiors with stark and unpalatable choices. The future Japan could be maintained under the U.S. boot as an increasingly resentful military dependency; or the U.S. could attempt the orchestration of a new balance of power in Asia and the western Pacific, with a fully sovereign Japan as an independent actor capable, within limits, of defending its own borders and interests. The first alternative was obviously self-defeating. The second had much to recommend it, except that it begged the question of whether it was politically, or even intellectually possible. To say the least, the idea ran against longstanding U.S. policy and public expectations. The destruction of Japanese militarism had lent the Pacific War its proper redemptive colorations as a moral crusade. Such attitudes, irrespective of whether they betrayed much understanding, had come to define official opinion nearly to the extent that they pervaded the popular mind. And considerations of balance of power had never been a particularly relevant, or even respectable, tradition within the annals of recent American diplomacy.

If an independent and rearmed Japan was likely to prove politically unacceptable to U.S. public opinion, congressional scrutiny, and military prerogatives, it was hardly less apt to find favor amongst the Japanese themselves; a consideration which Kennan discourteously omitted. Although they had huge reservations as to the feasibility of an unarmed neutral Japan, it should be recalled that Japanese leaders were equally convinced that their country would be unprepared economically, politically and psychologically to assume the entire burden of its external defense for the foreseeable future. But their discrepant 
desires, preoccupied with Japan's very real limitations, presented at the same time an inconsistent logic, and one prone to exploitation. The Japanese could not expect to exercise their sovereignty while others sacrificed to preserve it, without surrendering something in return.

At the end of May 1948, PPS 28 was submitted to the National Security Council for consideration by its members. As NSC 13/2, Recommendations with Respect to United States Policy Toward Japan, the report was forwarded for presidential approval on October 7, and Truman signed it two days later. In his memoirs, Kennan wrote that with the exception of the Marshall Plan he had made no greater contribution to government, and that never had he made such vast recommendations that met with such wholehearted approval. ${ }^{21}$ Indeed, when shorn of its analytical rational, the terse, cryptic language finally adopted was Kennan's own: "A final U.S. position concerning the post-treaty arrangements for Japanese military security should not be formulated until the peace negotiations are upon us. It should then be formulated in the light of the prevailing international situation and the degree of internal stability achieved in Japan. ${ }^{122}$

The long intervening months had nonetheless evoked subtle changes and shifts in emphasis. Because Kennan's original prescriptions were fraught with military significance, occasionally impinged upon military interests and privileges, and were largely dependent upon military officials for their final implementation (facts he clearly recognized), the Pentagon devoted special attention to their final 
formulation. The NSC was a forum in which the views of the armed services were well represented. ${ }^{23}$

This was nowhere more clear than the evolution of the finished recommendations regarding the naval base at Yokosuka. Kennan had merely noted that the Navy should shape its policy so as to favor the retention of its facilities at Yokosuka on a commercial basis in the post-treaty period. When NSC 13/2 was finally approved by the President the original recommendation was preserved, but with the following proviso: "This policy does not preclude the retention of a naval base as such at Yokosuka if, at the time of finalizing the U.S. position concerning the post-treaty arrangements for Japanese military security, the prevailing international situation makes such action desirable and if it is consistent with U.S. political objectives. ${ }^{124}$ Yet, by the logic of inter-service rivalry, if the prevailing international situation at the time of a peace treaty made it desirable for the Navy to retain bases in Japan, the other services could be expected to present their own legitimate demands for similar consideration. Thus, in October 1948, it became the official policy of the United States to seek to base U.S. forces in post-treaty Japan, though only under certain circumstances; ones neatly contingent upon Soviet behavior. The Soviets being who they were, there was every expectation that they would continue to behave badly.

In this at least, U.S. officials were not to be disappointed. Other countries did not fail to notice the rather bald reorientation of U.S. policy toward Japan during the course of 1948 . Even the British had cause to complain that they were 
not being apprised of the latest policy shifts. ${ }^{25}$ Under the circumstances, the Soviet reaction was predictable, as Robert Lovett intimated in cable sent to Secretary Marshall in Paris -- the very day NSC 13/2 was sent to the President's desk. "There is reason to believe Soviets have become alarmed over evidences of a shift of U.S. policies in Japan," from one of reform to stability, he told Marshall blandly, and were especially fearful of a "possible later intention to re-arm Japan in our service." Lovett advised the Secretary to indicate that the U.S. "has of course no plans of rearming Japan," while pointing out Soviet designs for gaining control of Japan "with view of drawing Japan into its orbit."26

Ambassador Panyuskin, Soviet Representative to the Far Eastern Commission, ended any speculation about his government's concerns in a statement issued at the end of October. Citing that tribune of Communist propaganda, the Associated Press, as his source, Panyuskin demanded a U.S. response to allegations that high U.S. military officials had conferred with General MacArthur in midOctober to discuss measures to be taken in the event of a surprise attack on Japan, although the Ambassador asserted benignly, "it is known for everyone that nobody threatens Japan." He also, in light of official FEC policy on demilitarization, ${ }^{27}$ desired a U.S. reply to assertions in the A.P. report that the naval base at Yokosuka was being expanded and modernized. ${ }^{28}$ The United States' rejoinder, which followed a few days later, specified that General MacArthur held discussions with U.S. military officials regularly on routine matters of sole concern to the United 
States; as for the implied charge that activities as Yokosuka violated FEC policy, these were "wholly without foundation." 29

Despite the public denials, the shift in policy was transparently, suspiciously real. These mutations, it perhaps does not need to be emphasized, did not develop in a vacuum. They were but a microcosm of an evolving global strategy being discussed and refined among Washington officials for waging and winning the intensifying battles of the cold war. Only days after George Kennan submitted his report on Japan to the Secretary of State, the National Security Council took under its consideration NSC 7. Although the document was never officially adopted, its far-ranging strategic assumptions colored the thinking of the highest national security officials for the greater part of 1948 , and beyond..$^{30}$ If the "Truman Doctrine" represented the attempt to combat the Communist offensive by means of a generous purse, the assumptions which gird NSC 7 laid the foundation for the world wide militarization of United States foreign policy.

"The ultimate objective of Soviet-directed world communism is the domination of the world," the report opened. Communist aims would be furthered by a combination of an aggressive Russian foreign policy and support for revolutionary movements, abetted by "the formidable material power of the USSR" and "the chaotic aftermath of the war." The defeat of the Axis powers left the United States as the only world power capable of resisting the inexorable Soviet thrust for global supremacy. 
But this contest would not merely pit the material resources of one super

power against the other. The victor would need a little help from its friends:

Between the United States and the USSR there are in Europe and Asia areas of great potential power which if added to the existing strength of the Soviet world would enable the latter to become so superior in manpower, resources and territory that the prospect for the survival of the United States as a free nation would be slight. In these circumstances the USSR has engaged the United States in a struggle for power, or "cold war," in which our national security is at stake and from which we cannot withdraw short of eventual national suicide.... [The] United States has open to it the organization of a world-wide counter-offensive against Soviet-directed world communism. Such a policy would involve first of all strengthening the military potential of the United States, and secondly, mobilizing and strengthening the potential of the non-Soviet world. ${ }^{31}$

The dizzy wedding of power politics and righteous crusading was to bequeath the cold war, from the American side at least, one of its dominant, and from the bemused (when not terror-stricken) perspective of U.S. allies, one of its least comprehensible themes. Though not explicitly stated as such, the logic of the analysis flowed both ways: if areas of "great potential power" lie prone to Soviet threat or inducement, they might also be held, or enlisted, to the cause of liberty. The organization of an armed camp spearheaded by the United States and directed towards the Soviet menace would thus become the prevailing concern of international affairs. To this end the report concluded, the foreign policy of the United States should be directed towards "building up the military potential of selected non-communist nations," a denouement with obvious implications for the Japanese future. ${ }^{32}$ 
In East Asia, Soviet machinations could be expected to be pursued with vigor. The region was ripe for mischief, concluded the State Department in the fall of 1948 , for reasons related to the "power vacuum" created by Japanese defeat, the ongoing civil war in China, and the shrinking influence of the European colonial powers and the related struggles for independence amongst their former subjects. ${ }^{33}$ Soviet policy would attempt to exploit these situations when opportunity presented itself. At the same time, Soviet policy would seek to undermine U.S. advantages, such as the "American domination of Japan and South Korea," and endeavor to neutralize U.S. objectives, like the creation of "U.S. strategic bases in the Far East. $^{134}$

During the final months of 1948, as the Soviets, from the American perspective, seemed poised to reap their bounty, U.S. policy in East Asia seemed mired in difficulties. The Chinese civil war was going from bad to worse. In September and October, Communist victories in Changchun and Mukden had led to the fall of Manchuria, and with it the surrender of 400,000 Nationalist troops. ${ }^{35}$ And the early October presidential endorsement of policies designed to further Japanese stability were seeming either eerily prescient or an example of too little, too late.

Ensconced in Tokyo, General MacArthur, perhaps still nursing a resentment over his abortive bid for the Republican nomination for President, was turning a deaf ear to the importunities of frustrated Washington policy makers vainly endeavoring to prod him into implementing the provisions of NSC 13/2. His refusal 
to moderate the purge of Japanese leaders, and augment the Japanese police were characteristically impudent and galling. ${ }^{36}$ While the General stalled, his Political Adviser, William Sebald, was transmitting worried cables back to Washington decrying the marked increase in Communist Party membership on Hokkaido, the northern island in visible range of the Soviet held Kuriles. ${ }^{37}$

The economy remained a shambles, and Japanese politics was more chaotic than usual. On October 15, after serving seven months, the Cabinet led by Ashida Hitoshi, the former Foreign Minister who had succeeded to the premiership after the collapse of the Socialist coalition headed by Katayama, was forced to resign in disgrace in the wake of a massive and complex bribery scandal. Ashida was himself arrested. With a marked lack of enthusiasm, the Democratic Liberal Party once again turned to the sixty-nine year old Yoshida Shigeru to form a caretaker government. Three months later, in January 1949, Yoshida gambled on calling a general election, and won an astonishing absolute majority in the lower House of the Diet, his party taking 264 seats out of $4666^{38}$ The victory, though no one knew it, was the dawn of a conservative hegemony that would last 44 years. At the time, it would have been possible to draw just the opposite conclusion. In the same election, the Japanese Communist Party, in an unexpectedly strong showing, elected 35 candidates and polled nearly 3 million votes, almost ten percent of all votes cast. $^{39}$ Not significant perhaps, in comparison with the success of Communist Parties in Europe, but worrying all the same. 


\section{NOTES}

1. FRUS, 1948, vol. 1: National Security Policy, p. 539.

2. Kennan, p. 382; and Michael Schaller, The American Occupation of Japan: The Origins of the Cold War in Asia (New York: Oxford University Press, 1985), p. 123.

3. MacArthur's presidential ambitions had become obvious by the fall of 1947 . By February 1948 the General and his staff began making serious preparations to enter primaries in a number of mid-western states. On March 9, right in the middle of Kennan's visit, MacArthur announced his candidacy and entered the Wisconsin primary scheduled for April 6th. As late as March 29, the New York Times was predicting a MacArthur victory. Nevertheless, Wisconsin's junior Senator, Joseph McCarthy, though still a relative unknown nationaly, chose to practice his unique brand of invective against the MacArthur candidacy, alleging that the General was a divorced homosexual supported by the Kremlin. MacArthur lost badly in Wisconsin, winning only eight delegates to Harold Stassen's nineteen. After he ran fifth in the subsequent Nebraska primary, he withdrew his name. See William Manchester, American Caesar: Douglas MacArthur 1880-1964 (Boston: Little, Brown \& Company, 1978), pp. 520-525.

4. Kennan, pp. 382-383; Schaller, p. 123.

5. FRUS, 1948, vol. 6, pp. 697-699; Kennan, pp. 383-384.

6. FRUS, pp. 699-700.

7. Kennan proposed, in essence, that since the terms of surrender, which the FEC had been charged with effecting, had been implemented, its policy-making duties had been completed, and the United States was in its right to decline to act upon directives which expanded those limitations. Ibid., pp. 703-705.

8. Ibid., p. 700.

9. Ibid., pp. 700-701.

10. Kennan, p. 387.

11. Ibid., pp. 388-389; Schaller, p. 125.

12. FRUS, 1948, vol. 1 (March 14, 1948), pp. 531-532. 
13. Schaller, p. 124.

14. FRUS, 1948, vol. 6 (March 21, 1948), pp. 706-709.

15. Frederick Dunn maintains that the organization of a police force of some 150,000 men became the goal of U.S. policy. Yet in neither Kennan's PPS 28, nor in its final version as NSC 13/2 were explicit figures named as to the desirable size of the Japanese police establishment, beyond the recommendation that such such forces be expanded and re-equipped. Dunn, p. 77.

16. FRUS, pp. 691-694.

17. During the first months of the Korean war, Kennan would come to recommend a quid pro quo with the Soviet Union rather similar to the plan first enunciated by MacArthur, with the U.S. promising a neutralized, demilitarized Japan in exchange for a like situation on the Korean peninsula. The proposal was adamantly rejected by Secretary Acheson. See Kennan's Memoirs: 1950-1963, vol. 2 (Boston: Little, Brown and Company, 1972), pp. 45-46.

18. FRUS, p. 712.

19. Ibid., pp. 712-713.

20. Ibid., p. 713.

21. Kennan, Memoirs, vol. 1, p. 393.

22. FRUS, p. 859.

23. A creature of the National Security Act of 1947 , the National Security Council included among its membership the President, the Secretaries of State and Defense, and the Secretaries of the three branches of the armed services, Army, Navy and Air Force.

24. FRUS, op. cit.

25. Sir Alvary Gascoigne, Head of the U.K. Liaison Mission to SCAP, sulked to Political Advisor William Sebald that "British officials are getting sore" at the apparent lack of communication and confidence displayed by their U.S. counterparts regarding the "fundamental changes" of U.S. policy towards Japan. Ibid. (March 29, 1948), p. 719.

26. Ibid., p. 864 . 
27. On June 19, 1947, the FEC ratified, with U.S. endorsement, the "Basic PostSurrender Policy for Japan," a document based on the Potsdam Declaration and the U.S.'s own Basic Initial Post-Surrender Directive, calling for complete demilitarization and disarmament of Japan. The Soviet Union hoped to embarrass the United States into upholding its earlier pledges in support of a highly punitive and restrictive disarmament, in an effort to curtail the new, and from the Soviet position, ominous, direction of current U.S. policy. The FEC decision was but another unfortunate artifact of the chaos which reigned over U.S. Japan policy in mid 1947. See Dunn, p. 66.

28. FRUS (October 28, 1948), p. 879.

29. Ibid. (November 4, 1948), p. 887.

30. NSC 7, Report by the National Security Council on the Position of the United States with Respect to Soviet-Directed World Communism, was introduced on March 30, 1948. The report was cancelled on November 23, 1948, at the 27th Meeting of the NSC, having been superseded by NSC 20/4, which was approved at that meeting. For the complete text see FRUS, 1948, vol. 1, pp. 545-550.

31. Ibid., pp. 546-547. The report had the decency to admit that there might be some drawbacks to waging the global struggle in the manner envisaged; namely, the permanent mobilization of the vast military resources such an effort would require might jeopardize the United States' status as a "free nation," the ostensible reason the battle was to be enjoined in the first place. The prospect of a United States transformed into the mirror image of its nemesis was not however, deemed sufficient reason not to plunge ahead with a program to increase arms (including nuclear) spending, reinitiate the draft, and to suppress subversives within our own borders. See pp. 548-549.

32. Ibid., p. 549.

33. "Pattern of Soviet Policy in Far East and Southeast Asia," Ibid. (October 13, 1948), pp. 638-644.

34. Ibid., p. 640.

35. Spence, p. 507.

36. FRUS, 1948, vol. 6 (October $27 \&$ November 10, 1948), p. 878 \& pp. 890-891.

37. Ibid. (November 9, 1948), pp. 887-890.

38. Dower, pp. 314-315. 
39. A. Roger Swearingen, Communist Strategy in Japan, 1945-1960 (Santa Monica, California: The Rand Corporation, 1965), p. 24. The vote represented the high point for the JCP and its electoral showing has never been repeated. 


\section{CHAPTER V}

\section{"PENTAGONIZATION"}

To U.S. officials and interested observers the results of the election of January 1949 pointed with foreboding insistence to a most undesirable trend: the growing polarization of Japanese political life. And there was not much disagreement as to its essential cause. It was the occupation itself. Henceforward, the occupation would be an issue, and a divisive one, in Japan's domestic politics, something it previously had not been.

Max Bishop, Chief of the Division of Northeast Asian Affairs, and Dr. Edwin Reischauer, then a professor of Far Eastern Languages at Harvard University, both wrote lengthy memoranda during separate visits to Japan in February 1949, and both reached remarkably similar conclusions. "I gathered," wrote Bishop, "from both Japanese and Americans with whom I talked that the recent election was a protest vote -- protest against the occupation." Mr. Yoshida, Bishop continued, had emerged as "a symbol of Japan's ability to stand up to the occupation," while the Communists had "openly and violently denounce[d] 'American imperialists' and the 'imperialist occupation."'1 Reischauer identified the growth of Communist sympathies to the same unequivocal opposition to the occupation. Defeat, he admonished, had been reserved for those parties and individuals who had been perceived as "collaborators" with SCAP. ${ }^{2}$ 
Despite the turmoil its presence was causing, both writers noted, in Bishop's words, SCAP's "smug isolation from the troubled events of the outside world." Disturbed, Bishop observed SCAP members busily devising "five year plans," while General Marquat, Chief of the Economic and Scientific Section of SCAP, professed that the State Department was "still 100 percent" behind the program of zaibatsu dissolution, a policy that ceased having Washington's support with the adoption of NSC 13/2 in October 1948. "These occupation people have got a Philippine complex," Bishop credits an American reporter as saying, "They expect to be here 40 years." "It became apparent to me," Bishop then summed up with something akin to understatement, "that it will require the strongest and most determined action possible on the part of the highest officials in Washington to break up the entrenched bureaucracy both in Tokyo and in Washington which has a vested interest in the continuation of the present activities of the occupation." ${ }^{13}$

The reports of both Reischauer and Bishop had alluded to a worrisome and curious paradox with which policy makers in Washington would be forced to contend from this point forward, even if they did not as yet recognize it. The desire for permanence on the part of a uniquely independent and distant military establishment had somehow to be reconciled with mounting Japanese desires to be rid of its ubiquitous presence and interference. That presence, furthermore, was one which had begun to divide and embitter Japanese politics. If the source of irritation was not removed, or at least meliorated, a backlash might conceivably be unleashed which would not only undo all that the occupation had tried to achieve, 
and make a continuation of a U.S. presence impossible. Larger strategic interests dear to Washington might be jeopardized as well. SCAP's permanence could only be tolerated if it, or something like it, could be fashioned into an instrument of Washington's policies, instead of pursuing its own course. Japanese leaders then would somehow have to be convinced of the wisdom of Washington's version of geopolitics. It was an assent which they were unlikely to grant however, if the cost entailed the breakdown of social control within their own country, as seemed highly probable. As the new Secretary of State Dean Acheson confessed in his memoirs with a diplomat's practiced circumlocutions, by the end of 1949, even under the best of circumstances, the feeling in Washington was that chances were no better than even that after the occupation's conclusion Japan would continue as the "liberal, democratic, and peaceful society we had sought to establish."4 The remarks are piously self-serving on the one hand, while being gloomily wrong headed on the other. For sophisticated men like Prime Minister Yoshida being prudently antiSCAP was not, by any means, the same as being opposed to the United States -rather the opposite in fact.

Difficulties are often resolved in unexpected, though not always desirable ways, and such was the case with Washington's Japan policy. Though not precisely anticipated, there was a certain inevitability which led to 1949 as being the year of the "Pentagonization," for lack of a better word, of Washington's approach to the myriad issues swirling about the Japanese future. The neologism might be awkward, but it could not be more accurate. Moreover, there was an element of default to the 
process. The ordered cessation of reforms left SCAP, now bereft of a program, as a kind of stagnant holding operation. Activity towards a peace treaty had been reduced to nil and so efforts on the diplomatic front remained moribund. With peace and reform no longer guiding policy, administrative and diplomatic considerations gave way before strategic concerns. The question of the hour was one that had been long ignored and one which neither State nor SCAP was equipped to answer: how to mount a serious defense of Japan?

Actually, when first given an inadvertent public airing, the question was not how, but rather should the United States be prepared to defend the Japanese home islands. On February 6, 1949, at an off-the-record Tokyo press briefing for U.S. correspondents, Secretary of the Army Kenneth Royall, whom Truman had affectionately called, in other circumstances, a "muttonhead,"5 held forth to the astonished journalists the proposition that in the event of war with the Soviet Union, Japan would not be an asset, but a liability, and that U.S. troops should be withdrawn from the country as quickly as possible. "One statement attributed to Mr. Royall," cabled a flustered William Sebald to the Secretary of State, "reads to the effect that the United States has no moral obligation towards Japan, that we are not in Japan at our request, and that even though it was our duty to disarm Japan it is not our responsibility if someone else cuts Japan's throat." Royall then compounded his faux pas the next day when he was quoted as saying that his previously expressed views were in accord with those of Washington and General MacArthur. Wrote 
Sebald icily, "I know that General MacArthur does not share the views voiced by Mr. Royall."

The comments caused a furor in Japan. Sebald stated that Royall's off hand remarks could not have been better designed to drive the Japanese to embrace the Soviet Union, so soon after Communist troops in China had captured Beijing. ${ }^{7}$ But though Royall, who retracted his words some days later, may have been a diplomatic oaf, he had only confirmed what those in Washington already knew. His tour of army installations in Japan revealed garrisons which were undermanned and unprepared to engage in hostilities, and Japanese forces, such as they were, which were unable to assist them. Yet from these circumstances it was possible to draw just the opposite conclusions. U.S. forces in Japan, Lt. General J. Lawton Collins, Army Vice Chief of Staff, told the New York Times in late February, should be boosted and reequipped, especially in light of the recent Communist victories. ${ }^{8}$

All this discussion only hinted at the considerable amount of behind the scenes activity taking place at the Pentagon, much of it ironically spurred by Royall himself, in the form of a query directed to the Secretary of Defense dated May 18, 1948, more than half a year earlier. That memo became in turn the Secretary's October 1948 request to the Joint Chiefs to study "Limited Military Armament for Japan." On March 1, 1949, the Joint Chiefs were ready with their answer.

Despite Royall's very public gaffe, his views were but an extreme voicing of a worrisome logistical and manpower problem. There was no doubt by this date that the United States was prepared to defend Japan if attacked, but in the light of 
global commitments and finite resources the maintenance of a credible arsenal remained problematical. A Soviet military presence in the Far East was estimated, in one study conducted in April 1949, to consist of 40 army divisions, 104 air regiments, and 109 naval vessels, a force which would be capable of overrunning Hokkaido within 30 days and subjecting the rest of Japan to aerial bombardment; certainly an exaggerated summary of Soviet strength and capabilities, but one palpable to anxious Pentagon planners. ${ }^{9}$

Already discussions leading up to the adoption of NSC 13/2 during the course of 1948 had indicated the druthers of the Joint Chiefs. "It may well become extremely important," the Chiefs commented on a draft of NSC 13/1, "for Japan to be capable of providing some degree of military assistance to the United States, at least to the extent of Japan's own self-defense."10 By the spring of 1949, "in view of the unsatisfactory world situation and the likelihood of its worsening," the Chiefs, led by Chairman Omar Bradley, the memo's author, were eager advocates of the obvious next step. NSC 13/2 had called for a strengthening of Japan's domestic security apparatus, but had adopted a wait-and-see approach to long term provisions for Japanese military security. This latter provision was now outmoded, even dangerous. It was time to incorporate Japan into the U.S. security structure.

The men at the Pentagon were not fools. They recognized at least some of the diplomatic, economic and constitutional problems associated with what they were advocating. Secrecy was of paramount importance. Discrete meddling in Japanese domestic politics to secure the necessary constitutional revision might be 
required. The Chiefs nevertheless believed that "The strengthening and equipping of Japanese police and coastal patrols be undertaken with the secret ultimate objective in mind of the use of these forces as a basis for the establishment of limited Japanese military forces for the defense of Japan." ${ }^{11}$ Secret, though informal, discussions with former members of the Japanese military soon followed. ${ }^{12}$ When the Joint Chief's proposed the furtive resurrection of the Japanese armed forces, under U.S. guidance and provisioning, it marked the final demise of an era in which the strategic thinking of the United States in Asia had been dominated by the residue of the Second World War. Henceforward, Japan, though not quite an ally (for its intentions were still too vague), was no longer the enemy, but a partner of sorts, albeit a reluctant one, in the strategy of containment.

The State Department, perhaps surprisingly, was also enthusiastic. It cautiously pointed out that both Secretary Royall and General MacArthur "agreed that it would be inadvisable for a long time to come to permit the establishment of Japanese armed forces," and that, "it would be wise before going too far in any planning to determine the attitudes and inclinations of Japan's leaders," a consideration which had somehow slipped the collective minds of the Pentagon brass. But these barriers were not seen as insurmountable, while the prior "commitments to disarm and demilitarize Japan" and "the sensibilities of our Allies and former friends," were the sorts of inconveniences that rendered "any consideration of this question...be undertaken only under extremely tight security requirements." The State endorsement for the secret rearming of Japan was 
wholehearted: "The National Military Establishment should...make plans now for the possible use of limited Japanese armed forces for the defense of Japan in the event of war."13 But by endorsing the rather sweeping shift in the direction of policy towards considerations of military security, the State Department, by implication, all but surrendered its influence over the direction of U.S. policy towards Japan to its rivals in the Pentagon, a mistake that it would tacitly acknowledge and regret. A major bureaucratic offensive would be needed to regain lost ground.

As the collapse of the Nationalist regime in China became a foregone conclusion with the fall of Nanjing in April and Shanghai in May 1949, the Pentagon's strategic reevaluation of Japan proceeded urgently apace. By mid-year the Joint Chiefs submitted their conclusions in a paper presented to the National Security Council titled NSC 49. Japan's geographical location, its human and industrial potential, when viewed against "the developing chaos on the Asiatic mainland" made the continued western orientation of Japan, and its denial to the Soviet Union, a vital matter of United States security. No peace treaty with Japan would be possible until assurances of Japan's future inclinations could "be established beyond all question." But such certainties, in the face of "aggressive communist expansion" would be profoundly difficult to cement, unless unambiguous guarantees could be applied in the form of the physical presence of U.S. garrisons. The potential for political instability in Japan made contemplation of a treaty "premature," because the report intimated, in a vague foreshadowing of a later 
Pentagon doctrine, "the risk of loss of control of any area might seriously affect our national security." ${ }^{14}$

An emboldened Pentagon pressed a comprehensive escalation of U.S. security requirements well beyond the confines of previous understandings and commitments: "If it should prove impracticable or impossible to obtain bases on the Japanese main islands, bases on Okinawa or other islands of the Ryukyus along with other U.S. bases in or near the Pacific would not meet our essential needs." Such needs had expanded beyond the "control" of the Sea of Japan, the Yellow and East China Sea; Japanese bases "would provide us with staging areas from which to project our military power to the Asiatic mainland." The securing in perpetuity of the Navy base at Yokosuka, though obviously only a beginning, should be considered a matter of "major importance." Thus any contemplated treaty "should not be such as to preclude bilateral negotiations for base rights in the Japanese main islands." $^{15}$

But not surprisingly, the preservation of military prerogatives was merged more or less synonymously with the essential preconditions of military security. The much desired "stabilizing influence" of U.S. bases would be "vitiated" if they were located in remote areas so as not to inconvenience the locals, and "efficiency and effectiveness" would be undermined; and a "moral problem of major dimensions" was bound to erupt if these bases were not crawling with dependents of servicemen. Furthermore, the cost of maintaining this presence would largely fall to the Japanese hosts. $^{16}$ 
An unanticipated and somewhat qualified endorsement of the methods, if not the conclusions of the Joint Chiefs was subsequently received from a most unexpected quarter, the Foreign Office of the British Government. On September 9, 1949, in a Washington conversation between Sir Esler Dening, the UK Assistant Undersecretary for the Far East, and an assemblage of the State Department's Far East officers, Mr. Dening observed that as there could now be no peace treaty with Japan that secured vital U.S. interests acceptable to the Soviet Union, the Western Powers should proceed with a treaty without Communist participation. When asked whether such a treaty would actually end up compromising U.S. security, he deftly proposed that U.S. interests might be best preserved through a bilateral pact which would secure U.S. bases in Japan during the post-treaty period. He further felt that such an arrangement would be viewed favorably by the Japanese, who, he asserted, desired protection almost as much as the return of their sovereignty. ${ }^{17}$ Dening then suggested that Congress would be more inclined to continue providing funding for the prodigious cost of the occupation if the U.S. were to maintain a military commitment in the form of bases. These and other proposals were followed up a week later at higher level meetings between Secretary Acheson and Foreign Secretary Ernest Bevin. At the conclusion of these talks, although their contents were obviously not divulged, Acheson held a press conference in which he stated that the UK and the U.S. would again commence serious effort towards securing a Japanese peace treaty. ${ }^{18}$ 
Secretary Acheson's new found haste to conclude a treaty, though influenced no doubt by restive Japanese and a fickle Congress, and prodded by pledges he had made to Bevin to have ready a U.S. draft for the contemplation of British diplomats by years end, may have also been motivated by a desire to wrest the momentum of U.S. Japan policy away from the Department of Defense. The prestige and reputation of the State Department had suffered publicly from the dismal progress of events in China. A successful Japanese treaty might right the balance and boost sagging morale. On September 16, while the Bevin talks continued in Washington, Acheson recorded an unusual exchange between himself and President Truman regarding the procedure to be followed in the drafting of the treaty:

I said that as a first step we were going to ask the $\mathrm{N}$ [ational]M[ilitary]E[stablishment] to ask the Joint Chiefs to advise us on the essential security requirements for the United States point of view and that my talk this morning was merely an explanation of the reasons for that request. Mr. Early [the Deputy Secretary of Defense] said that the matter would be given prompt attention. It was understood that if we wrote a letter, it would contain merely the request for advice. Mr. Early thought it was unnecessary to write, but the President was inclined to believe that the question might be sharpened for consideration if it were reduced to writing and that it might be useful to have a record of the request. ${ }^{19}$

The President's suspicions, in retrospect, were remarkably prescient. On October 3, the request, in writing, was received by Secretary of Defense Louis Johnson.

By then, State had already begun to mount a counter attack within the NSC against what it perceived to be the heavy handed approach of the Joint Chiefs to the intertwined issues of U.S. and Japanese security. Upon the principle that the denial of Japan to the Soviet Union and its future alignment with the United States should 
be the overriding objective of U.S. policy there was broad agreement, but State Department officials sharply reminded the Pentagon that that outcome depended more upon the attitudes and orientation of the Japanese people than it did upon the military capabilities of the United States. The State Department too had taken to heart lessons of the Chinese debacle, though quite different ones from those of their Pentagon colleagues. Paramount among them was the need to build and foster popular support: "The U.S. can neither impose nor enforce a pro-western orientation on any foreign people, including the Japanese," continued the rebuke, therefore, "from a political point of view, the achievement of our objectives with respect to Japan are now less likely to be thwarted by proceeding promptly to a peace treaty than by continuance of the occupation regime." Post-treaty bases, in the opinion of the State Department, would "constitute an irritation and not a stabilizing influence on the Japanese population. ${ }^{20}$

The Pentagon, needless to say, was undissuaded. It had taken a relatively long time for Defense planners to come around to a Japan conceived of, not so much as a potentially sovereign entity around which agreements could be negotiated, such as the recently concluded NATO pact, but as a valuable and exploitable military asset. But the idea once set could not be shaken for the very good reason that the concept was one of almost unlimited potential, while the alternative, in this black and white world, was catastrophic. The United States could not afford another China. The primary interest of the United States in Japan was now overwhelmingly strategic and the minimal security priorities were unmistakably 
clear: Japan must not fall to the Soviet camp; the U.S. must secure bases in Japan after a treaty of peace; Japan must be rearmed so as to stem internal subversion and aid the U.S. in the event of a Soviet armed assault. World events only reinforced this determination: the Soviets had successfully tested a nuclear weapon near the end of September, and the People's Republic of China was declared on October 1, 1949. In Germany, a similarly conceived program of rearmament was already underway. Pentagon planning sensibly directed itself towards attaining the objectives and thwarting the obstacles, principally erected by the State Department, which blocked the way.

It would be erroneous to convey the impression that officials at the State Department held views that varied substantially in essentials from those which held sway in the corridors of the Pentagon. The men at Foggy Bottom were no less perplexed and unnerved by global events, and in their policy prescriptions weighed the same factors and came to similar conclusions. The dispute increasingly centered on the optimum methods by which to secure agreed upon objectives. State did not object to plans for eventually rearming the Japanese. Whatever resistance to the idea of maintaining military bases there soon disappeared, provided that the Japanese themselves could be persuaded to request them. And both sides agreed to the need to commit a future Japan to the United States. For the military this was primarily a technical question. There was a dawning realization that the perpetuation of the regime of occupation, unencumbered by questions of local and national sensitivities, provided the ideal environment in which the land and 
resources of Japan could be utilized to maximum effect. Any nagging distrust or doubts as to Japanese intentions could be ignored, or if need be, repressed. In essence, Japan could be construed as one vast base.

At the State Department, this approach was considered ruinous and ultimately self-defeating. Only by decisions taken by the Japanese themselves could its future political affinities towards the United States be secured with any hope of permanence and stability. Japan could be coaxed, if need be gently coerced; but it could not be bullied into an alliance that deeply offended its national sensibilities. It was, in a sense, a gamble. The Soviet Union and China could conceivably entice Japan into their orbit with promises of the now desperately needed markets and raw materials upon which pre-war Japan had once heavily relied. Nevertheless, Japan's future orientation could only be arrived at by a Japan whose sovereignty, by way of a peace treaty, had been restored. A generous treaty of peace was viewed as an opening gambit to persuade the Japanese that an alliance with the west provided the surest means to a free and prosperous future.

What remained of the good will between State and Defense in the fall of 1949 was fated to evaporate by year's end. Differences over Japan's future descended into a bitter personal and incommensurable quarrel that extended beyond questions of policy to impinge upon those timeless matters of bureaucratic politics -- careers, prestige and influence. Under Acheson's direction, the State Department hurriedly proceeded to fashion the draft treaty that the Secretary had, in the course of their September meetings, promised to deliver to British Foreign 
Secretary Bevin by early December. On October 13, a draft, minus the security requirements, which were still under consideration by the Defense Department, was readied. Bevin and Acheson had already reached a meeting of minds as to the utter necessity of securing Japan for the west, believing that to do so would demand the conclusion of a generous, non-punitive treaty which would welcome the Japanese as an equal member of the family of "free nations" aligned with the United States. After the U.S. and the UK had reached agreement on the draft, Bevin would then present it to a meeting of Commonwealth Foreign Ministers scheduled for January, some of whom had not as yet come to appreciate the need to treat the Japanese with a benign hand. It would fall to Bevin to persuade them otherwise. Crafted with an eye towards this understanding, and following closely the precepts embodied in NSC $13 / 2$, the draft was the first Japanese treaty fully conscious of the cold war stakes involved. ${ }^{21}$

By the end of October, the Defense Department had still not complied with Acheson's request to enumerate the necessary security requirements, and the Secretary began to suspect that Pentagon foot dragging, led by Under Secretary of the Army Tracy Voorhees (whose dilatory tactics Acheson described as "infinitely resourceful") and his deputy liaison with the Department, Major General Carter B. Magruder, was being carried out with the express purpose of undercutting further progress on the treaty. ${ }^{22}$ The intensifying bureaucratic struggle taking shape in Washington even caught the attention of General MacArthur, who, in early November dispatched an emissary in the person of Colonel C. Stanton Babcock to 
brief the disputing parties on his long considered views. Both sides sought to construe the General's wisdom as added weight to their own position.

The visit of Colonel Babcock confirmed the degree to which a condominium of common interests between SCAP and the Pentagon had been gradually, perhaps even unconsciously, constructed over the year that had elapsed since the reorientation of U.S. policy, signified by NSC 13/2, had been officially adopted. With an individual as idiosyncratic and unfettered as General MacArthur at the helm in Tokyo the marriage was, of course, not a perfect fit as to all the particulars. Important differences remained, and others, in time, would grow. The future Japan envisaged by the Joint Chiefs did not jibe fully with the one conceived by MacArthur's overdeveloped sense of destiny. Still, the fundamental issue boiled down to one of permanence, the desirability and feasibility of a prolonged United States military presence on Japanese soil, and here at least the American Caesar had reconsidered his earlier views, at least as reported by Colonel Babcock to an assemblage of State and Defense officials, including Magruder and Assistant Secretary Butterworth, convened on November 2nd.

The Colonel's opening remarks could not have given the Defense nay-sayers much comfort. The General considered a treaty long overdue, and endorsed the procedure worked out by the State Department to enlist the support of the Commonwealth members. MacArthur, according to Colonel Babcock, still believed however, that Soviet participation in any treaty was desirable, and that Japan's unarmed neutrality under a system of security guarantees remained the most 
desirable course. He had come to recognize, nevertheless, that Soviet behavior and attitudes being as they were, such an arrangement might not be possible at the present time. $^{23}$

Since Japan's unarmed neutrality was "impractical for an indefinite period, the General had come to favor another approach at considerable variance with his previously stated position that Japan's security could be easily vouchsafed by the positioning of U.S. forces on Okinawa. MacArthur's change of heart entailed "the U.S. to retain naval and air bases in Japan after a treaty for the primary purpose of making it unmistakably clear to the USSR that aggression against Japan will mean all-out war with the United States." The Soviets were not likely, MacArthur felt, to risk such an encounter. Yet Colonel Babcock indicated that MacArthur believed that the U.S. should "keep itself free to add to its military strength in Japan after the treaty to any extent it considered necessary and desirable."24

The Colonel added that the General endorsed the British proposal of a bilateral pact to be negotiated between Japan and the United States as a separate agreement, which would then come into force simultaneously with the treaty. MacArthur "was confident that the great majority of Japanese would welcome a U.S. - Japan agreement providing for the retention of U.S. forces in Japan after the treaty," but did not further elaborate as to the evidence for this conclusion. The State Department position that any forces stationed in Japan should be located in "remote" areas MacArthur dismissed as "unrealistic." Then, sowing confusion in his wake, Colonel Babcock professed the General's complete agreement with the 
contents of NSC 49, in which the Joint Chiefs endorsed a position that a peace treaty with Japan was "premature." All this was music in the ears of Major General Magruder, his one disappointment stemming from MacArthur's adamant refusal to heed any suggestion that Japanese armed forces be reinstituted, or to be persuaded of their manifest usefulness. Yet a far from discouraged Assistant Secretary Butterworth conveyed to Colonel Babcock upon the meeting's adjournment the apparently sincere sentiment "that the State Department's present thinking corresponded closely with General MacArthur's. ${ }^{125}$ Both parties, in all honesty, could fairly conclude that they had come away from this bewildering performance with the conviction that General MacArthur had thereby tilted his not inconsiderable influence firmly to their respective camps. MacArthur may have desired to create just such an impression.

December was not a particularly good month for Secretary Acheson. Republicans in both houses of Congress, lambasting the loss of China and the alleged infiltration of the State Department by Communists, made very public calls that President Truman fire him. He had of necessity become embroiled, since November, in the debate over whether the United States should produce the $\mathrm{H}$ bomb, which, beyond the evident strain of the decision itself, brought him into regular contact with the cantankerous, some suspected mentally unbalanced, Secretary of Defense Louis Johnson, and the two men developed a mutual and abiding animosity. Japan was almost the least of Acheson's worries. 
Acheson was not unaware that the time table he had worked out with Foreign Minister Bevin was falling further behind, nor would Bevin let him forget it. Acheson recalled: "Bevin had been after me directly and through Ambassador Franks to give him an outline of our thoughts." The Commonwealth Conference was fast approaching, and a Japanese treaty, "probably a highly punitive one," would be a topic of discussion. ${ }^{26}$ On Christmas eve, Acheson wrote to the British Ambassador, Sir Oliver Franks, to express regret that the Department would be unable to meet the agreed schedule:

On a good many aspects we have been able to reach tentative conclusions, but unfortunately in the very important matter of security we have not as yet been able to find satisfactory answers to certain basic problems confronting us....I feel it might be helpful for $\mathrm{Mr}$. Bevin to know the general nature of some of our difficulties. ${ }^{27}$

Acheson was embarrassed at having failed to meet the deadline. Earlier that day he had not failed to convey his irritation to the Joint Chiefs Chairman, General Omar Bradley. The Commonwealth members would accuse the U.S. of foot dragging, he scolded Bradley. It would become an item in the press, get back to Japan, and cause an unfavorable reaction in the Japanese people, who were anxious for a treaty. But the real source of Acheson's ire, and the reason for the hastily scheduled meeting, was the memo he had received the previous day from Secretary Johnson, which after long delay conveyed the essential security guidelines to be followed under any Japanese treaty, as formulated by the Joint Chiefs. "I regret," Johnson wrote cryptically, "that it has not been possible to answer your letter (of 
October 3rd) at an earlier date, but I know that you have been kept informed of the reasons which prevented this." ${ }^{28}$

The Chiefs had elucidated the "minimum military requirements of the United States" in the following terms: 1) The United States was to be the only foreign country with the right to operate military facilities on the Japanese islands; 2) The United States must exert a strategic trusteeship over the Marianas, Caroline and Marshall islands, and secure exclusive control over the Ryukyus south of latitude 29 degrees north; 3) U.S. bases would be required at Okinawa, Yokosuka, and "Army and Air Force bases generally as at present." The next requirement was the shocker: "From the military point of view the Joint Chiefs of Staff consider that a treaty to be acceptable must include both the USSR and the de facto Government of China as party signators to the document." "Since it is apparent," the Chiefs continued, "that the minimum military requirements and the requirement that the USSR be a party signator are probably mutually exclusive, the Joint Chiefs of Staff reaffirm their previous view that negotiations now, leading toward a peace treaty with Japan, are still premature. ${ }^{129}$ Though he was not yet prepared to discuss the whole of the Joint Chiefs findings at that time, Acheson informed Bradley, one item he could not let pass. This conclusion, Acheson intoned with withering irony, was a "masterpiece of understatement." 30

Briskly, almost contemptuously, Johnson had informed Acheson that he concurred in the Chiefs opinions, but he conceded, with a certain relish, that the 
decision of the Defense Department might result in a public relations difficulty, yet another problem to be flung into the lap of the Secretary of State:

I am concerned about the psychological effect upon the Japanese...resulting from the wide-spread public discussion during recent months about an early treaty, including extensive debates in the Japanese Diet. This prospect has raised great hopes in Japan. I feel that we must promptly give consideration to the steps necessary to deal with this very real problem. ${ }^{31}$

Acheson personally delivered his letter to Sir Oliver; the two men considered each other friends. Part apologia, part plaint, the Secretary's informal memorandum dissected the American security conundrum with rare cogency and earnestness. "The United States has been acutely aware that the basic problem underlying a treaty is security," Acheson confessed, "that is, to avoid any peace settlement which would weaken the United States security position in the western Pacific," carefully adding, and that of "like-minded powers." The problem was not a lack of resolve, as the Secretary well understood, but one in which equally pressing objectives appear as mutually exclusive and contradictory:

The United States also appreciates that the security clauses in the treaty must be dual in purpose: security against renewed Japanese aggression and security for Japan against Soviet-Communist aggression. The two aggressive threats appear closely related, however, for in its present state of complete disarmament Japan can be realistically regarded as a future threat only if allied or in cooperation with Soviet military might. ${ }^{32}$

Whether friend or foe, the treatment to be meted out to the Japanese will be the same regardless, due to the awesome specter of Soviet power stalking the Asian landscape. 
Through a glass darkly, Acheson contemplated the USSR as "the great and expanding power in Asia," an event that had its origins in Japan's defeat. Had he considered it, Acheson might have attributed his current dilemma to the same cause, while pausing to ponder the meaning of the United States as "the great and expanding power in the Pacific." He did not of course; nor did he display an awareness that the Soviet Union of his description, in an odd and inexplicable phenomenon very near the heart of the cold war, there lay hidden a classic case of psychological reversal, the fiendish doppelganger whose motives are the mirror of one's own. To make Japan theirs, the Soviets were "already pursuing the familiar Communist patterns of infiltration, subversion and propaganda," and using all means of intimidation to subdue a passive, obedient people. The intensification of these tactics was but a certainty, "for were Japan added to the Communist bloc, the Soviets would acquire skilled manpower and industrial potential capable of significantly altering the balance of world power. ${ }^{133}$

"However much a treaty may be desirable," Acheson laments, "one which fails to give Japan adequate protection against Communist aggression, outright or subversive, may well be worse than no treaty at all." But the kind of protection Japan needs might not be the kind of protection Japan wants, or would even tolerate, making it possible to mistake American concern for old-fashioned domination, a cure worse than the disease. Yet neutrality would be illusory, and rearming Japan to a degree sufficient to provide for its own defense a political 
impossibility. By default, U.S. forces based in Japan remained the only viable option, but a risky one:

If arrangements for the retention of these forces were to be concluded with Japan in a bilateral agreement...it would be necessary to specify the period of time for their retention and, possibly, their size. Because of uncertainties in the whole Far Eastern picture, the time limit and size of forces would have to be on the maximum side. This in turn raises the serious question of unfortunate psychological reactions in Japan and other Far Eastern countries. ${ }^{34}$

It was a uniquely American response to the burden of empire, and perhaps the Secretary found solace in confiding his tweaked conscience to a distinguished servant of a world-weary diplomatic tradition. To be imperial, yet to not seem imperial, was an exquisite and uncomfortable dilemma which skirted the definition of hypocrisy. Power and perception, as is often the case, were at a sizable variance. To reconcile them would require a touch of good fortune and a large dose of deception.

Over the course of 1949, United States policy towards Japan had evolved a new hierarchy of values, with "security" perched boldly at the pinnacle, and to which all other considerations were systematically subordinated. In this, Japan policy was by no means unique, but rather symptomatic. Policy terms, the framing of policy debate, and the crafting of policy options as a result of this valuation became the province of the Pentagon. While the State Department was relegated to the role of discovering the most politically palatable way to implement Pentagon desires, the Pentagon, as it had demonstrated, easily squelched those initiatives which were not to its liking. The new values had a new hierarchy of bureaucratic power to 
accompany them, from which they were mere emanations. To his chagrin, Dean Acheson had discovered that, in the new Washington, the advice of a Secretary of State was no match for the demands of the Joint Chiefs.

If the State Department had been largely superseded in the crafting of of U.S. policy, the Japanese, whose destiny was being decided, were altogether absent. This was largely a vestige of the terms of an unconditional surrender which left the United States free to dispose of Japan as it chose, unburdened of the obligations of consultation with a defeated enemy. But legally sanctioned domination, whatever its administrative benefits and efficiencies, its absolute and unchallenged prerogatives, left an insidious imprint upon the psychological climate of the victor, as well as the vanquished. A taste for superiority is soon acquired and reluctantly relinquished, but seldom consciously acknowledged, yet all the while permeating and defining the boundaries of human relationships. United States policy had set itself the difficult task of winning over the Japanese while subduing them, paternalistically, for their own benefit. The baggage which both sides would bring to this effort at reconciliation would make it more difficult still. That the times demanded otherwise was manifest, but the barriers which lay strewn about the mind were not so easily cleared away. Racial attitudes which had long been nurtured on American soil, then coupled with the cult of victory, made it all the more unlikely that U.S. officials could come to regard a defeated, Asian people as their equals, while Japanese concordance and cooperation demanded no less. 


\section{PERMANENT NEUTRALITY}

While the political alignment of the post war world troubled the thoughts of the Washington establishment, the second Yoshida Cabinet was forced, during most of 1949, to devote itself to less grandiose, but no less vital matters. As the State Department and the Pentagon bickered over security, the Japanese Government struggled with an economy on the verge of total collapse. This sorry state of affairs was, once again, the result of an American initiative, the Dodge Plan. ${ }^{35}$

Joseph Dodge was a former car salesman and Detroit banker who managed to fashion this meager experience into a reputation as a tough-minded, levelheaded guru of economic reconstruction. He had cut his teeth on the Marshall Plan, and it was on this basis that he came to Japan in February 1949 to implement the policy of economic recovery and stability which had been declared the main objective upon which all other aspects of U.S. policy hinged, with the approval of NSC 13/2 in October 1948. The appointment of the extremely conservative Dodge, however, seemed to represent the triumph of domestic politics over strategic design.

For the needs of the reconstitution of a vast, complex industrial economy (ostensibly the policy of the U.S.), the single-minded Dodge had nary a notion, and his conception of economic stability was equally idiosyncratic. The Dodge "Nine Point Stabilization Plan" as it was called, had as its goal the snuffing out of Japanese inflation and the return of a stable currency, with the aim of prompting Japan to self-sufficiency by 1953 . But the devil was in the details, and a mere glance at the Dodge plan betrays its real concerns; not the invigoration of Japanese industry, but 
the end of Japan as a U.S. taxpayer "burden," and the breaking of the power of Japanese unions.

Dodge was a believer in balanced budgets. To this end, his program all but suspended the infrastructural repair projects of the Japanese Government and forbade subsidies to essential private industries like coal and electrical power generation. Even food subsidies were curtailed. What little capital was available was redirected to export industries, namely textiles, to earn foreign exchange. The result was an end to what little economic recovery had already occurred and the degradation of already low living standards.

Between 200,000 and 400,000 union workers in the public and private sector lost their jobs due to spending cuts, but protest strikes, by SCAP orders, were forbidden. ${ }^{36}$ Sinister incidents of industrial sabotage, like the infamous "incident" at Matsukawa, were staged throughout the summer months, in response to the systematic use of firings to purge the labor unions of radicals and activists. Even the fiercely anti-Communist Yoshida Government balked at implementing measures of such political unpopularity and draconian severity.

Worst of all, the plan did not work. Just as Dodge had achieved his balanced budget by mid-year, the economy began to slide into a depression as the anticipated earnings from exports failed to materialize. Few nations, despite persistent U.S. pressure, were prepared to accept Japanese exports, and in September, the devaluation of the pound sterling priced Japanese exports out of the few markets in which they had a precarious hold. In desperation, SCAP allowed the "dumping" of 
Japanese goods below cost, beginning in October. The winter of 1949-50 promised to be one of the most difficult since the end of the war.

The deterioration of economic conditions throughout the year only intensified the ominous trend towards political polarization which had so troubled American observers in January. The incidents of sabotage, the burgeoning "red" purges, the unmistakable tactics of intimidation practiced on unions and their members all pointed to growing and irreconcilable differences within Japanese society brought about by the changes in occupation policy. These essentially domestic disputes were exacerbated by the end of 1949 by being interwoven into the international tensions and crisis atmosphere of the cold war, inevitably spilling over into questions of Japanese foreign policy. The process institutionalized the divisions in Japanese political life, much to its future detriment. The result, the marginalization of democratic government, was an unintended outcome, perhaps, but one in which the United States bore a considerable measure of responsibility. For at its core there dwelt an aggrieved sense of nationalism, spurned on by a sense of betrayal.

On December 10, 1949, the Japanese Socialist Party (JSP) formally committed itself to a foreign policy of "permanent neutrality." The stance, which over the decades has been virtually synonymous with the Japanese left-wing, was at the time remarkable for its abruptness. In the words of one scholar, "There is in fact no evidence that before 1949 neutrality was ever seriously considered within the JSP as a post-independence policy for Japan." ${ }^{37}$ The announcement was the outcome 
of several factors, some obvious and already mentioned -- cold war anxieties and domestic political reversals -- while others were less apparent but no less decisive, such as the role of factional squabbles within the JSP. But "permanent neutrality" was more than a policy. It became a banner, a slogan, an ideological credo which embodied implicit assumptions beneath its facade of pacificism, revolution and antiAmericanism. It was in many ways a fantasy nationalism born of impotence, which selectively borrowed rhetoric and symbols of the Japanese past to re-envision a destiny for Japan that emphasized the uniqueness and special mission of the Japanese people to bring about an ideal world. Needless to say, that world was at some variance with the one to be meted out to Japan as the junior partner in an American enterprise, and as such it touched a popular chord.

While the direction of U.S. security policy was all too clear in Washington, to the Japanese it remained a cryptic and inconsistent enigma. Regrettably, the mouthpieces of U.S. policy were often loose cannons, beginning with the statements of Army Under Secretary Royall in February (in which he conveyed, with a tactless honesty, the decidedly secondary importance of Japanese security to the United States in comparison with western Europe). This episode was then followed by a March interview given by General MacArthur to a British journalist, in which he made his notorious "Switzerland of the Pacific" analogy, and was further reported to have said that the United States had no interest in, and never intended to regard Japan as an ally. ${ }^{38}$ The U.S. was a distant and fickle power, the Russians and China immediate and possibly threatening presences. Under these circumstances, 
Japan's permanent neutrality, a policy option which had not been seriously contemplated since the winter of 1947 near the end of the first Yoshida Cabinet, was given a dusting off. When debated in the Upper House of the Diet in April 1949 , neutrality found some supporters (but curiously, none from the JSP) ${ }^{39}$ while Prime Minister Yoshida held to the view that neutrality was an unwise and unrealistic course. $^{40}$

Following word of the Acheson-Bevin talks of September when it became clear that Japan's alliance with the United States after the signing of a peace treaty was a primary objective of U.S. policy, Yoshida publicly adopted a passive attitude, telling an Australian reporter, "It is important for us to be patient and moreover we can afford to wait," while privately instructing the Foreign Ministry to study the ramifications of a "separate peace" without Soviet or Chinese participation. ${ }^{41}$ An early November leak from Occupation Headquarters confirmed the revised opinions of General MacArthur, the same ones which only days before Colonel Babcock had presented in Washington to U.S. officials; namely, that Japan's future security would demand the permanent retention of U.S. bases. ${ }^{42}$ Subsequently, the Prime Minister informed a Diet session convened to debate the renewed prospect of an early peace, in a provocative display of public candor, that the options for Japan had become a separate peace or no peace, though in discussions with Foreign Ministry officials he still expressed the hope that U.S. bases in Japan proper might be avoided. ${ }^{43}$ Yet, when questioned in the Diet about U.S. bases, Yoshida equivocated, answering that "it was not possible to answer such hypothetical 
questions," a reply which only earned the Prime Minister the opposition charge that he was keeping secrets. ${ }^{44}$

A month later the JSP adopted the policy of permanent neutrality. The abrupt about face in U.S. policy, or so it appeared to many Japanese, seemed solely motivated by a cynical desire to use Japan as a base to stem the growth of communism in Asia, a perspective by no means confined to left-wing circles. In a poll conducted in late November, only 20 percent of the Japanese interviewees expressed a desire to depend on the United States for the country's security. ${ }^{45}$ In opposing the American ploy, the JSP hoped to strike a blow against both foreign domination and the collaborationist conservative opposition, while at the same time restoring to themselves some of the public legitimacy that had already seriously eroded well before the period of massive lay-offs and purges damaged their credibility still further. The January elections which had returned Yoshida to power witnessed the loss of nearly 100 seats by the JSP, from 143 to 48 . The disaster brought the left-wing faction to positions of Party leadership in April, and with it the expected ideological re-orientation. ${ }^{46}$

The "Three Peace Principles" of permanent neutrality, as they came to be known a few months later, ${ }^{47}$ supported an "overall" as opposed to a "separate" peace, disarmament and neutrality in world affairs, and an opposition to foreign military bases and military alliances. Their formulation owed an intellectual debt to the deliberations of the Peace Issues Discussion Group (Heiwa Mondai Danwakai), a convocation of concerned university academics with leftist sympathies but no 
official ties to the JSP, ${ }^{48}$ and the example of non-alignment set by Nehru's India. The aim of the policy, in the words of Party leader Suzuki Mosaburo, should be to "consolidate Japan's economic self-reliance within world peace and friendship."49

There was a good deal of self-interest interspersed within the well meaning rhetoric of socialist idealism. Understandably, many Japanese, not just socialists, were not eager to see their country once more transformed into a battleground over issues which many believed remote from their own concerns. Alliance with the United States not only held out this dubious prospect, it also, many felt, smelled of the continuation of the occupation by another name, U.S. bases a continuous reminder of national humiliation and defeat. And there was more than ideological affinity behind the socialist insistence that Japan's economic independence rested upon a resumption of ties with China, regardless of the regime in power. Even conservatives worried how Japan was to rebuild its broken economy without trade with the mainland. Those ties were likely to remain severed if Japan moored itself to the United States, with the unenviable possibility that by doing so Japan would be relegated to a second-class status within the economic pecking order of the capitalist world.

But dependence on the communist bloc was not what the socialists had in mind either, despite the belief, as one Party intellectual put it, that "The defeat of capitalism would remove the main cause of war. If the whole world became socialist...the cause of today's wars would disappear."50 The Russians perhaps, were more admired than feared, and China's leadership were fellow travelers along 
the road of historical destiny: still, Japanese socialists, as representatives of an "advanced" nation had a special, but not altogether coherent obligation to assert their national independence in order to better promote world peace and socialism by upholding the pacifist ideals embodied in the Constitution. By eschewing the "entangling alliances" proffered by the west, and thus with no reason to dread the east, Japan would pioneer a new international role for itself by serving as a lone harbinger and leader by example, thus making a unique contribution to a vaguely defined but grandly encompassing global peace.

Yet the substitution of utopian ideals could not mask the fact that the rhetoric of the left, self-consciously shorn of military chauvanism, echoed the nationalist rhetoric of co-prosperity. All the elements were there: the desire for independence from communist and capitalist alike; the need to join with China to promote economic self-reliance; of a singular obligation arising from novel circumstance to advocate the cause of peace. That the devastation of the last war made efforts to avoid the next a political imperative comprise the understandable motivation behind the policy of the JSP. The twinned assumption, that by following such a course as envisaged by the JSP, Japan could somehow avoid becoming enmeshed in the unpleasant realities of international power politics, betrayed a desire for the illusory at the expense of the real. It is not difficult to see the psychological shock of defeat operating behind the urge for a kind of political quietism, for isolationism and withdrawal from a complex world. But it would be a mistake as well to ascribe the mood as uniquely a phenomenon of the left, for the 
pairing of economic interests and political passivity was a combination which had much to recommend it. Some Japanese quite clearly understood that though ideals could not protect Japan, the United States could.

Questions of the practicability and wisdom of "permanent neutrality" as a foreign policy long haunted Japan's political left. Yet at the time it was introduced it did not seem so outlandish, and until just before its adoption such a policy contained the essence of the thinking of no less a figure than General MacArthur. Later events caused some to reconsider, and subsequent and bitterly fought political battles caused the policy to harden into a kind of dogma, which was often worn as a badge of resentment and defeat. A number of commentators have remarked upon the Japanese fondness for the doomed cause, but over time the policy of permanent neutrality took on a symbolic aspect beyond its intended display of antiAmericanism, that of political irresponsibility, and hence the impossibility of governing. The reduction of politics to political theater might satisfy an aggrieved sense of outrage, but in the JSP's choice to serve as a ritual, rather than a real opposition, Japanese democracy was compromised. In the short term, however, the JSP's foreign policy seemed to have a genuine popular appeal. In a House of Councillors election held in early June 1950, the JSP emerged as the second largest Party after Yoshida's Liberals. ${ }^{51}$

By the beginning of 1950, the persistence of the occupation and the ominous changes in U.S. policy had exacerbated the political and ideological cleavages in Japanese society, but as yet they had not permanently hardened. By the end of the 
year those divisions had been cemented like statutes into the political landscape, even as they cracked open under the strain of war. 


\section{NOTES}

1. FRUS, 1949, vol. 7 (February 18, 1949), p. 660.

2. Ibid., p. 663 .

3. Ibid., p. 661.

4. Dean Acheson, Present At the Creation: My Years at the State Department (New York: W. W. Norton and Company, 1969), p. 429.

5. McCullough, Truman, p. 648.

6. FRUS (February 12, 1949), p. 648.

7. Ibid., p. 649. The Red Army entered the old Ming capital on January 31, 1949, after a Nationalist surrender. See Spence, p. 508.

8. Dunn, p. 79.

9. Operation Gunpowder was a study issued by the Far East Command April 12, 1949. Its findings were discussed by Miki Hideo, "Aspects of U.S. Strategy for the Defense of Japan," The Occupation of Japan: The Impact of the Korean War, Proceeding of the Seventh Symposium Sponsored by the General Douglas MacArthur Foundation, October 1986, ed. William F. Nimmo (Norfolk, Virginia: The General Douglas MacArthur Foundation, 1990), pp. 48-49.

10. FRUS, p. 672.

11. Ibid., p. 673 .

12. A Japanese American reported to the intelligence division of Naval Operations, Far East, on regular twice weekly meetings with former Japanese Naval officers to explore the issue of rearmament, beginning in 1949. See James E. Auer, The Postwar Rearmament of Japanese Maritime Forces, 1945-1971 (New York: Praeger Publishers, 1973), p. 275.

13. FRUS (April 1, 1949), pp. 694-696.

14. NSC 49, "Strategic Evaluation of United States Security Needs in Japan," Report by the Joint Chiefs of Staff (June 9, 1949), Ibid., pp. 773-777. 
15. Ibid.

16. Ibid.

17. Ibid., p. 854 .

18. Dunn, p. 83.

19. FRUS, p. 860. In his memoirs, Kennan also speculates that activity on a peace treaty was undertaken for reasons other than a propitious international situation, revealing a diary entry from mid- 1949 which read, "It is ironic that our principal reason for wanting a treaty of peace [with Japan] at this time is that it appears to be the only way of solving internal administrative difficulties within our own government." Kennan, Memoirs, vol. 1, p. 394.

20. "Department of State Comments on NSC 49," FRUS (September 30, 1949), pp. 870-873.

21. Dunn, pp. 83-84.

22. Acheson, p. 430.

23. FRUS, pp. 890-891.

24. Ibid.

25. Ibid., pp. 776-777.

26. Acheson, p. 430.

27. FRUS, p. 927.

28. Ibid., p. 922.

29. Ibid., p. 923.

30. Ibid., p. 924.

31. Ibid., p. 922.

32. Ibid., p. 927.

33. Ibid.

34. Ibid., p. 928. 
35. Excellent discussions, from quite different perspectives, on the Dodge plan, to which I am indebted, are given in Joyce and Gabriel Kolko, The Limits of Power (New York: Harper and Row, 1972), pp. 521-524; and Johnson, pp. 198-203.

36. Masumi Junnosuke states that 230,000 government workers alone were fired, while Cole, Totten, and Uyehara put the total number of fired workers at "more than 400,000." See Masumi Junnosuke, Postwar Politics in Japan, 1945-1955, trans. Lonny E. Carlile, (Berkeley: University of California Institute of East Asian Studies, 1985), pp. 187-188; and Allan B. Cole, George O. Totten, and Cecil H. Uyehara, Socialist Parties in Postwar Japan, (New Haven, Conn.: Yale University Press, 1966), pp. 330332.

37. J.A.A. Stockwin, The Japanese Socialist Party and Neutralism: The Study of a Party and Its Foreign Policy (London: Melbourne University Press, 1968), pp. 33-34.

38. Stockwin, p. 32.

39. Stockwin, p. 32.

40. Dower, pp. 373-374.

41. The quote is from Gerald R. Curtis, "The Dulles-Yoshida Negotiations on the San Francisco Peace Treaty," Columbia Essays in International Affairs, vol. II, ed. Andrew W. Cordier (New York: Columbia University Press, 1967), p. 40; Igarashi Takeshi, "Peace-Making and Party Politics: The Formation of the Domestic-Foreign Policy System in Postwar Japan," Journal of Japanese Studies, vol. 11, no. 2 (Summer 1985), p. 327.

42. Stockwin, p. 33.

43. Dower, pp. 373-374.

44. Igarashi, p. 333.

45. Dunn, p. 93.

46. Stockwin, pp. 35-36.

47. At the Party convention in April 1950. Igarashi, p. 342.

48. For a concise account of the group, see Igarashi, pp. 343-347.

49. Stockwin, p. 34.

50. Sakisaka Itsuro, quoted by Stockwin, p. 37. 
51. Igarashi, p. 348. 


\section{CHAPTER VI}

\section{MR. SECRETARY}

When Secretary of State Dean Acheson gave his lengthy policy address, "Crisis in Asia - An Examination of U.S. Policy,"1 before the respectful assembly at the National Press Club on January 12, 1950, he had little reason to suspect that in less than two weeks he would be caught in the center of one of the most vituperative and ignominious episodes in U.S. history. On this day his remarks ranged wide afield, arguing by implication that nationalism, not communism, was driving the politics of Asia; though his refrain, "no nation and no people are wise enough and disinterested enough very long to assume the responsibility for another people," has had, in retrospect, a certain unheeded poignancy. Yet, after denouncing Soviet imperial designs in Inner Mongolia and Manchuria ("the single most important fact in the relation of any foreign power with Asia," he called it), the Secretary intimated that in some circumstances disinterestedness would suffer significant exceptions:

...the defeat and the disarmament of Japan has placed upon the United States the necessity of assuming the military defense of Japan so long as that is required, both in the interests of our security and in the interests of the security of the entire Pacific area and, in all honor, in the interest of Japanese security....I can assure you that there is no intention of any sort of abandoning or weakening the defenses of Japan and that whatever arrangements are to be made either through permanent settlement or otherwise, that defense must and shall be maintained. ${ }^{3}$ 
This declaration of intent to use the Japanese archipelago as a bastion of U.S. security in the Pacific did not entirely jibe with another Acheson assessment, namely "we must clearly understand that the military menace is not the most immediate." Contradictions of this sort did not trouble the Secretary, who then laid out in very explicit terms (largely borrowed from General MacArthur) the "defense perimeter" of the United States, an island arc which ran from the Aleutians, through the Japanese islands, down the Ryukyus to the Philippines. Whether the omission of Taiwan, whose fall to the forces of the mainland was anticipated by the State Department in the form of a pre-prepared statement to be released upon that eventuality, ${ }^{4}$ and South Korea, where U.S. occupation forces were being withdrawn, was meant to signal an abandonment of these lands to their allotted fate beyond the pale of U.S. concerns, was left purposefully ambiguous. Any people "determined to protect their independence from outside aggression" he added presciently, must look to the assistance of the United Nations. The Secretary may have only been reflecting upon his own ongoing battles with the Pentagon when he informed his audience that it was a mistake "to become obsessed with military considerations," when the threat of "subversion and penetration" was so much greater. ${ }^{5}$

A different threat loomed much closer to home than Acheson realized even as the Soviet Union abandoned the UN Security Council and the Chinese sacked the U.S. consulate in Beijing in the days immediately following the Secretary's address. Acheson's defense of his friend, State Department colleague and former classmate Alger Hiss upon the latter's conviction on charges of perjury (related to 
his alleged passing of secret documents) on January 21,1950 , unleased in the Secretary's words, "the attack of the primitives." Acheson tendered his resignation, but Truman refused to accept it. Both men apparently thought the episode a one time outburst, even as the invective on the floor of the U.S. Senate moved far beyond the usual bounds of decorum and descended into personal smear: "I look at that fellow, I watch his smart-aleck manner and his British clothes and that New Dealism in everything he says and does, and I want to shout, 'Get out! Get out! You stand for everything that has been wrong in the United States for years!"' bellowed one mid-western Republican. ${ }^{6}$

Within a tense fortnight the unearthing of a real spy, Klaus Fuchs, who had passed real atomic secrets to the USSR, following hard upon the announcement by President Truman that the United States would construct a hydrogen bomb, was capped by the Wheeling, West Virginia antics of Wisconsin's junior senator, as Joseph McCarthy waved the paper which held the names of first 205, then 57, then 81 known Communists lodged in the heart of the State Department, during the course of a cross-country, publicity seeking odyssey. Acheson was a ready target of McCarthy's invective. Acheson, "a pompous diplomat in striped pants, with [a] phony British accent," as McCarthy caricatured him for the resentful American masses, had "proclaimed to the American people that Christ on the Mount of Olives had endorsed Communism." In the wake of this, and other such masterpieces of character assassination at McCarthy's hand, the Secretary became the recipient of 
such virulent hate mail that his personal safety appeared compromised, and armed guards were posted continuously at his residence. ${ }^{7}$

\section{THE SOVIETS IN ASIA}

The real Communists seemed almost benign in comparison. On February 14, 1950, China and the Soviet Union published the contents of the Treaty of Friendship, Alliance and Mutual Assistance. In essence a security agreement against renewed Japanese aggression, alone or in conjunction with allies, this crowning achievement of two months of Moscow negotiations was not perhaps the reward Mao had in mind upon announcing his intention to "lean to one side." The Chinese leadership had more pressing needs than those addressed in Article I of the treaty:

Both High Contracting Parties undertake jointly to take all the necessary measures at their disposal for the purpose of preventing a repetition of aggression and violation of peace on the part of Japan or any other State which should unite with Japan, directly or indirectly, in acts of aggression. In the event of one of the High Contracting Parties being attacked by Japan or other States allied with it, and thus being involved in a state of war, the other High Contracting Party will immediately render military assistance with all the means at its disposal. $^{8}$

Clearly, the treaty was far more beholden to Soviet concerns than a reflection of Chinese desires, and as such, could be construed as either a provocative escalation of the military stakes in Asia, or an attempt to put a bold face on an acknowledged defeat. The Soviets had not failed to heed the language employed by the Secretary of State before the National Press Club in regard to Japanese security. 
"The American imperialists," wrote Pravda, commenting on the Acheson speech, "have settled down in Japan and have no desire to leave it." Whatever the current impasse between the State and Defense Departments over the desirability of Soviet participation, the Soviets themselves were highly aware that the momentum towards a "separate peace" was being driven by the ultimate goals of U.S. policy which sought to fashion a post-treaty Japan into a military ally of the United States. So that there would be no confusion as to the quid pro quo involved, the very day on which Pravda published the official interpretation of the Sino-Soviet Treaty, the paper prominently featured excerpts of a recent U.S. News and World Report article which detailed a February visit to Tokyo by the U.S. Joint Chiefs in search of permanent military bases. ${ }^{10}$ When Article II of the Treaty of Friendship rather wanly insisted that both Parties "strive for the earliest conclusion of a peace treaty with Japan, jointly with the other Powers which were allies during the Second World War," it rang as an anxious protest of impotence before the inevitable.

The Soviet inability to meaningfully redirect the course of Japan's international orientation had as its counterpart a reinvigorated, if somewhat misguided application of Soviet efforts to influence Japan's domestic politics. Pointedly excluded from SCAP's administrative machinery, the Soviet voice in occupation affairs was by and large that of marginal and futile protest. That voice grew in boisterousness as the direction of the occupation changed, but not in effectiveness. The Japanese Communist Party (JCP) and its leader, Nosaka Sanzo, had likewise emphasized the Party's independence from Kremlin whims. Slogans 
such as "towards a lovable Communist Party," belied any notion that the JCP, even at its most disruptive, ever acted as more than the most pallid of "fifth columns" in the furthering of Moscow's global agenda. ${ }^{11}$ Of far greater detriment, Moscow's propaganda had little hope of altering the historical anti-Russian bias of many Japanese. Soviet troops occupied the Kurile islands and the USSR was suspected of continuing to hold hundreds of thousands of Japanese prisoners captured during the Manchuria campaign at the close of the war, employing them as virtual slave labor and subjecting them to rigorous indoctrination. ${ }^{12}$

Though the successes of the JCP in the January 1949 general election held any criticism of its tactics at bay, the year of glaring reversals which followed the initiation of the Dodge program had left the JCP and its leader vulnerable to outside pressures. Throughout January 1950 the Cominform, Pravda, and the Chinese Party organ, Renmin ribao (People's daily), in a naked bid to rein in a prodigal, issued a series of fierce attacks against Nosaka and the JCP for their perceived lack of revolutionary zeal and their program of "peaceful revolution," thereby throwing the Party still further into confusion and crisis. Nosaka was forced to make a full confession of his ideological and tactical errors, and a new program for the JCP, with Moscow's approval, which called for the fulfillment of the disarmament provisions of the Potsdam Declaration, opposition to a separate peace, and a renewed emphasis on direct action, was quickly announced. Yet unlike many of his European comrades subjected to similar criticisms, Nosaka retained his position of Party leadership, an indication perhaps, that the JCP's independence 
from Moscow was not just judicious propaganda, even as closer ties between the JCP and the Soviet Mission in Tokyo were being established. ${ }^{13}$

Even as renewed wave of left-wing and labor agitation gripped the Japanese economy in February 1950, joining Communists and Socialists in protest against the government's deflationary economic policies, and the Prime Minister's tacit acceptance of the idea of a separate peace, it was possible to interpret the recent flurry of Soviet actions and statements in regard to Japan not as evidence of aggressive design, but as a diplomatic smokescreen created to mask a Soviet retreat.

Or so concluded officials of the U.S. State Department by early March. The Russians had for the most part abandoned any hope of concluding an overall peace along the lines of the Potsdam Declaration, or of seizing control of the Japanese Government through the JCP. Instead:

Soviet actions, particularly the recent demand for the trial of the Emperor as a war criminal, the Sino-Soviet treaty of alliance directed against Japan and its Allies, and the purge of the Japanese Communist Party....suggest that the USSR has determined to concentrate its attention on China and Southeast Asia rather than on Japan and is preparing to cope with a situation formalized along the lines of an anti-Communist bloc including a pro-Western Japan and based on United States military power. For these purposes the USSR and Communist China have substantial capabilities which cannot be ignored and which would be tremendously increased should there be further substantial Communist successes on the Asian continent. ${ }^{14}$

That the prospect of a resurgent Japan intimately linked to the military might of the United States was the cause of concern and dismay within the walls of the Kremlin, the depth of which can only be guessed at, there is small room for doubt. A historic anxiety about the vulnerability of its geographically remote Far Eastern 
domains, when spurred by memories of recent invasion, called up the strategic and logistical nightmare of a two-front war. Confronting a situation which they had only the most indirect means of effacing, the Soviet leadership, in quite unremarkable fashion, pursued those policies which afforded the best means of providing for their country's security needs with those resources at their disposal.

But in the rough and tumble game of geo-politics, it could be argued that the Russians held, in North Asia at least, a certain advantage. Having played for high stakes there before, they knew the terrain. U.S. officials, on the other hand, seem to have been oblivious to the whys and wherefores of the struggles which had been waged in that corner of the world during the half-century before the Pacific War. It was Major Meckel, a nineteenth century Prussian officer charged with building Japan's first modern army, who first coined the strategic truism that has since become a cliche, that Korea was "a dagger thrust at the heart of Japan." The security of the peninsula had long been an obsession of Japanese military men, and the central point, as the Russians had once recognized, from which to counter Japan's military potential. It was a fact which Acheson had seemingly forgotten when drawing his "defense perimeter" in the Pacific, perhaps because U.S. officials had come to view the corrupt and autocratic regime of South Korea's Syngman Rhee as an intractable nuisance and liability. ${ }^{15}$ Stalin had a better memory and knew no such scruple when he conferred with North Korea's Kim Il-Sung in January 1950, when Kim presented his plan to unify the country by force. When assured by 
his advisors that the United States would not intervene to save the South, Stalin approved the plan. ${ }^{16}$

\section{A COUNTEROFFENSIVE}

Soviet policy in Asia, in its mixture of subterfuge and ambiguity, and by jumbling elements of resignation and threat, had left itself open to a wide disparity of interpretation. To no surprise, nervous policy makers in Washington were quick to seize upon those elements most congenial to furthering their own particular agendas, and no one more skillfully than the man who had the most to lose, the embattled Secretary of State. The dilemmas confronting Dean Acheson during the early months of 1950 were not small ones. His person and his department were under siege by the most unscrupulous of domestic demagogues and his rabid allies. The unforgiving political climate only made the ongoing bureaucratic stalemate with the Pentagon and the Secretary of Defense over the advisability of a Japanese peace treaty all the more treacherous. As Acheson recognized, "a public battle with Louis Johnson over a wholly false claim that the projected settlement neglected essential defense requirements, while appeasing the Japanese aggressors and perpetrators of the Bataan Death March, would be fatal to the treaty."17 And he might have added, damaging to the President and the Department of State, and probably fatal to his own tenure as Secretary.

His public views seem to have undergone a radical change in a very short time. The Acheson of the National Press Club speech of mid-January, which had 
minimized the Soviet military threat and emphasized the political force of Asian nationalism (an answer of sorts to his China critics), had given way within a month to the Acheson who was the guiding force behind NSC-68, with its rejection of "containment" of Soviet power as inadequate without "the military power to deter, if possible, Soviet expansion, and to defeat, if necessary, aggressive Soviet or Soviet directed actions of a limited or total character." To meet the global threat, cast in the most apocalyptic of terms, U.S. defense budgets would need to be tripled and taxes raised, the U.S. economy, and that of its allies would be mobilized for war. If this course was not followed the U.S., in the face of the Kremlin onslaught, would appear weak and irresolute, and (in a passage directly relevant to the difficult situation in Japan) "our allies and potential allies...as a result of frustration or of Soviet intimidation [will] drift into a course of neutrality leading to Soviet domination."18

The language employed in the drafting of NSC-68 had been an unconscious parody of his critics: "Qualification must give way to simplicity of statement, nicety and nuance to bluntness, almost brutality, in carrying home a point," Acheson admitted, when the purpose had been to "bludgeon the mass mind of 'top government,"' as he himself had been bludgeoned. ${ }^{19}$ The Secretary's renewed zeal to confront the Soviet threat was an understandable, if unnerving, reaction to the political attacks he had endured, a way of stiffening and staring down his myriad enemies: the Russians, Louis Johnson (whom Truman had appointed to his post to scale back, rather than engorge the Pentagon, and who protested angrily that 
Acheson's policy would bankrupt the country), and his Republican critics. But even Truman, the Secretary's strongest supporter, was wary of the political and economic implications of the massive military build-up prescribed in NSC-68, and weighed, perhaps, the overwrought circumstances under which it had been advanced. The President seems not to have made any attempt to implement its recommendations, and had it not been for the events of June, the report might have simply languished. As late as June 1, 1950, he declared that in his view the world was more stable than at any time since he had assumed his office. ${ }^{20}$

Although he had now donned the garb of global warrior, Acheson was determined to go forward on the Japanese treaty. Yet being the diplomat he was, he realized that in his battles with the Pentagon and Defense Secretary Johnson, that though his adversaries had taken an indefensible position, they could not be taken by direct assault. Acheson began methodically to chip away at the Joint Chiefs stand by undermining the dubious reasoning underpinning it, until at last it would be no longer credible. Towards this task he was able to enlist allies, the most important of whom was the President.

The Joint Chiefs, it will be remembered, had responded to an October 1949 request by the Secretary of State to define the essential U.S. security requirements which any negotiated peace with Japan must fulfill. The answer, which came December 23, 1949, stated in essence that negotiations on a treaty were inadvisable because U.S. security demanded that the Soviet Union and China must be party to a treaty which would provide for the permanent basing of U.S. troops in the Japanese 
home islands, a condition the USSR and the PRC were certain to reject. In reality, it was but a grotesquely obvious ploy to maintain unaltered the regime of occupation, but it was put forward under the pretext of a legal quibble of dubious authority: since the USSR and China had signed the Potsdam Declaration and were still technically at war with Japan, a treaty without their signatures would perpetuate their so called "rights of belligerency" allowing them to demand similar base rights or engage in hostilities of various sorts with impunity. Considering the Soviets' usual indifference to the subtleties of international law, and the Pentagon's lack of expertise, it was a slim reed upon which to delay a critical foreign policy initiative, a view in which the President concurred. At the conclusion of an NSC meeting of December 29, 1949, only a week after the submission of the Joint Chiefs recommendations, Truman reminded those assembled that the surrender terms of the Potsdam Declaration had been drawn up by the U.S., the U.K., and the Nationalist Government of China, without Soviet participation, as the Russians were not yet at war with Japan, and had only agreed to the terms at the time of Japan's surrender:

The President said that the U.S. position in Japan was a partnership affair with the UK and China and that the peace settlement must be a matter which is satisfactory to the United States and the UK. It may be that we shall want to attempt to negotiate such a settlement with the Russians, but he had no doubt that the United States and the United Kingdom could negotiate a peace treaty with Japan whether the USSR participated or not. ${ }^{21}$

Then it was General MacArthur's turn. "General MacArthur is quite outraged by the views of the Joint Chiefs of Staff in regard to the postponement of 
arrangements for negotiating the Japanese Peace Treaty," Ambassador at Large Phillip C. Jessup cabled Secretary Acheson, following a series of meetings the Ambassador held with the SCAP on January 9 and 10, 1950. "He spoke very strongly on this subject," Jessup continued, "and feels that the view does not really reflect a military judgement but that [JCS Chairman] General Bradley is merely speaking for Secretary Johnson," an observation that must have been highly gratifying to the Secretary, since it confirmed his own views. ${ }^{22}$ It was, in any case, MacArthur's frequently expressed opinion that the Joint Chiefs ought, and expected to be overruled, and that Acheson ought to strongly advise the President to do so. They had no familiarity with the problems, the General fulminated, and in an interesting reversal, expressed gratitude at the great cooperation he had received from the State Department, while intimating that his current troubles all stemmed from the Department of Defense. ${ }^{23}$

Always ready to perceive a personal affront, the touchy General furthermore claimed his views had never been solicited by the JCS. This was patently untrue. As recently as early December 1949, Under Secretary of the Army Tracy Voorhees had journeyed to Tokyo to consult with MacArthur in his capacity as deputy to the Secretary of Defense for policy in occupied areas. MacArthur's views had simply been unheeded in Washington, or when particularly uncongenial to the JCS position, deliberately misstated by $\mathrm{Mr}$. Voorhees to the State Department. ${ }^{24}$ Or so it seemed. Because the apparent confusion seemed at the heart of the bureaucratic logjam, and because of the tremendous stakes involved, Ambassador Jessup was so 
bold as to suggest that MacArthur be called directly by the President to explain his position, even though MacArthur had told Jessup, with all modesty, that he had no desire to intrude upon or influence policy decisions. Acheson's response to this was decidedly lukewarm. "He told me he saw no reason for circulating this to anyone," wrote Lucius D. Battle, Special Assistant to the Secretary in a memo to the Director of the Executive Secretariat, William J. McWilliams, referring to the proposal in the Jessup cable, "At any rate, the Secretary wanted this played very close."25

MacArthur never made the pilgrimage to Washington. Instead, it was resolved that the discrepancies between what MacArthur was alleged to have told Mr. Voorhees and what he had told the State Department would be reconciled by a direct call upon the SCAP by the members of the Joint Chiefs, which took place in early February 1950. "The oracle," as Acheson snidely referred to MacArthur, "gave his military colleagues small comfort. ${ }^{126}$ In fairness, it seems that in the past the apparent contradictions in MacArthur's statements had arisen from a combination of altered circumstances and a not uncommon propensity to say what his audience at the time desired to hear. Nor could it be said that the General's views would not change yet again. But on this occasion, the SCAP reiterated for the JCS the position which he had previously conveyed to Ambassador Jessup, and apparently the disingenuous Voorhees. MacArthur maintained that work on a peace treaty, and a generous one, must proceed. Japanese neutrality, guaranteed under a Monroe Doctrine-like arrangement still remained the most desirable course and one to which the Russians were likely to consent, but if this were not possible a renewable 
five year base agreement should be negotiated with the Japanese Government. A massive U.S. presence was to be avoided. Total forces of about 35,000 men would be stationed at five bases: a naval base at Yokosuka; an army base at Yokohama: and three air bases, one at Itazuke on the southern island of Kyushu, one at Yokota north of Tokyo, and another at Misawa on the northern tip of Honshu, just south of Hokkaido. $^{27}$

MacArthur believed that he and the Chiefs, as a result of their discussions, had reached a meeting of minds. Surprisingly, the JCS more or less agreed with MacArthur's basing proposal, although they desired more men, 75,000 as opposed to 35,000 , and worried as to whether in time of war Japan could be permanently held. ${ }^{28}$ Agreement as to the defensive nature of the U.S. position was also earnestly vouchsafed. "I questioned him [MacArthur]," noted Assistant Secretary for Far Eastern Affairs, Walton Butterworth, in a memo of a conversation held immediately after the Chiefs departure from Tokyo:

...about whether the Joint Chiefs entertained the view, as Mr. Voorhees had more than once implied, that bases in Japan were to be used in the future for forward air operations against Russia in time of war. General MacArthur said decidedly not, that bases in Japan now and for the future are and would be for defensive purposes only, and that the Joint Chiefs had no other concept in mind. ${ }^{29}$

This may have been no more true than another of MacArthur's sincerely held beliefs, that the JCS would soon reconsider their opposition to a treaty. Under MacArthur's questioning, JCS Chairman Omar Bradley was reported to have said that arriving at this view the matter had been only "lightly considered," yet from the villainous Voorhees, MacArthur explained, "who entertained such exaggerated 
views about this matter that he would doubtless resign rather than be party to a peace treaty," only intransigence could be expected. But seeking to exploit a possible rift within the Pentagon, MacArthur had not been as persuasive as he supposed. Meeting with President Truman on their return to Washington, Voorhees informed MacArthur, the JCS "were still strongly of the opinion that it is premature to make a treaty at this time, and that they had so orally advised the President. ${ }^{130}$

Still, the possibilities for mischief were not lost upon the Defense Secretary, who told Acheson that direct State Department discussions with MacArthur on military matters were an "offside play." In his usual abrasive style, Johnson demanded that Acheson channel all State Department contact with SCAP involving security policy through Tracy Voorhees. It was a request which was, in Acheson's words, "quietly ignored."31

While Defense and State officials were voyaging back and forth from Tokyo, others in the State Department were searching for some sort of method by which the demands of the Pentagon and the desires of the Japanese for a treaty could somehow be reconciled. At a meeting convened in Washington on January 18, 1950, attended by Acheson, Butterworth, Special Assistant to the Secretary John B. Howard, and Deputy Under Secretary Dean Rusk, two proposals were considered. The first envisaged an agreement which would restore normal political and economic relations to the Japanese while keeping in place the regime of occupation with respect to security; the second, the conclusion of a formal peace treaty in 
conjunction with a negotiated arrangement for the maintenance of U.S. military bases on the Japanese islands. The methods may have differed, but the ends were the same: without the presence of U.S. forces an unarmed Japan would present "a vacuum into which Communist forces would not hesitate to move, with the consequent growth...either of a totalitarian militaristic regime of the right or a Communist instrument of 'Slav imperialism[!]."132

Butterworth favored the first option. Although the Japanese would be disappointed in their desire for a treaty, the Assistant Secretary argued that they would accept the proposal as the best that could be achieved under the circumstances, and additionally in his view, because of the imposed nature of the settlement, it would leave the Japanese Government less vulnerable to the ongoing Communist propaganda that it was about to forsake the Japanese people to the interests of "western imperialism." A cleavage that would result from a separate peace that would force governments in Asia and the Pacific to openly side with either of the superpowers could be avoided, he maintained, and most importantly, the proposal would satisfy JCS worries that a separate peace would undermine U.S. security in the Pacific. ${ }^{33}$

The second option also had its advantages. The combination of anxious desire on the part of the Japanese to secure a treaty and the recognition by the Japanese leadership of their country's weak security position presented the United States with a "unique opportunity which may not again recur." By dangling the prospect of a treaty, the United States would most likely be able to win acceptance 
of a long-term basing agreement from the Japanese as being the most readily available solution to the country's security needs. But coercion, no matter how mildly clothed, contained its own risks, as Butterworth recognized. That the move would represent the final break between the United States and USSR and the PRC over Japan was a foregone conclusion. The greater consequences would stem from the influence such a resolution would exert over the kind of rapport the two nations could hope to develop in the future. With great discernment, Butterworth advised that taking such a position "would commit the U.S. to [a] long-term pattern of political relationships based on Japan's consent to U.S. bases and [a] nakedly military U.S. posture in Japan." ${ }^{34}$

At the meeting Acheson rejected what was referred to as "the stand-by SCAP approach." There was no reason to believe that this "devious and obscure course of action," the phrase of a State legal advisor, ${ }^{35}$ offered fewer obstacles than the more straight forward process of securing a treaty. Though likely to be favored by the JCS, Acheson considered their position simpleminded and overly legalistic, for the Secretary was of the opinion that Soviet behavior did not rest upon legal pretexts, but upon considerations of power, opportunity and advantage. Thus, it would be foolish to think the Russians and the Chinese would be likely to sweetly accede to such a proposed change in the "regime of control," and their rabid objections that such a move was a violation of previous Allied agreements would, ironically, have at least as great a legal merit than any they could put forward in opposition to a peace treaty. It was an argument which the Secretary would have a chance to repeat, when 
on March 24, 1950, Tracy Voorhees came forward to offer a nearly identical Defense Department version of the plan. ${ }^{36}$

In rejecting the first proposal, Acheson underscored that he clearly understood the real reasons the JCS were wary of a treaty. They were fearful any change might entail increased security risks, that once SCAP's power to dictate to the Japanese was removed there were no guarantees of that Japan would continue its pro-Western stand. A Japan free to determine its own political and economic relations might be tempted into a security alliance with Communist powers in exchange for markets or other advantages. But the Pentagon, Acheson believed, had failed to adequately ponder the repercussions of narrowly considered desires. If Japanese resentment over the continuation of the occupation should turn violent, the U.S. would be forced into acting as an instrument of repression, poisoning and undermining the ultimate objective of securing a friendly Japan. And internationally, it would be a source of grave concern to allies if it were believed that the U.S. desired to remain in Japan indefinitely under the occupation, creating in effect a Japanese puppet state, in preference to a peace treaty. ${ }^{37}$

With a touch of cynicism born of long contact with their military colleagues, it was advanced that State might be able to sell the Pentagon on a treaty by insinuating that there were certain advantages which would accrue from Japan's independence, not the least among them that "a peace treaty will hasten the time when the rearming of Japan will be politically feasible." Yet many of the same political disadvantages which held for a continuation of SCAP in its military, rather 
than its administrative, capacity dogged considerations of a bilateral U.S.-Japan base agreement under a peace treaty. It was the appearance of an outright military alliance conveyed by such an agreement that had spooked the JCS into fear of provoking the Soviets and Chinese to the point of hostilities. Japanese public reaction was certain to be prolonged and overwrought, damaging to both U.S.Japanese relations and Japanese political stability. It was Dean Rusk who suggested the possible avenue of egress from the security labyrinth. Acheson suggested that he further develop the idea, which he did over several weeks. On February 20 th, the Secretary met with the President (who said he had been worrying about lack of progress on Japanese matters), and outlined the Rusk proposals. The President pronounced the ideas as "hopeful."138

On March 9, 1950, a detailed outline of the suggested course of action had been prepared. It was, in all its essentials, yet another example of the fondness of American diplomacy, when confronted by the thorny dilemmas of the cold war, to embrace the notion of collective security as a kind of panacea. Somehow U.S. objectives would remain cleverly submerged and very nearly forgotten beneath the hearty cries of all for one and one for all. The "Pacific Pact" as Rusk envisaged it, would comprise the U.S., Canada, the Philippines, Japan, Australia and New Zealand. It would address Japan's admitted security needs by providing for U.S. bases in Japan. But the bases would be part of the multilateral effort, presumably so as not to provoke Japanese public opinion. As an international agreement in keeping with the U.N. Charter, the United States could avoid appearing as an 
"imperialist" both in Japan and the rest of Asia, while Japan would thereby be snugly affixed to the community of "free nations." The pact would also gradually provide for eventual Japanese rearmament, but in a context believed to be domestically acceptable and one which would not give rise to undue fears from Japan's nervous neighbors.

The last mentioned item was far from the least important, because the terms of the treaty of peace would be in large measure dictated by the kind of security agreement which would accompany it. Officials in the State Department, Walton Butterworth in particular, had come to understand as early as November 1949 that in exchange for acquiescing to the kind of non-punitive peace treaty desired by the United States, other nations, Australia foremost among them, would seek security guarantees from the U.S. as a hedge against the possibility of renewed Japanese aggression. If they were not forthcoming, Australia, and perhaps others would insist upon a treaty modeled on Versailles. ${ }^{39}$ At the time, Butterworth foresaw that these multiplying requests for U.S. security commitments would create a demand among the nations of the Pacific for a NATO-like pact, the creation of which he strongly advised against. Burgeoning obligations would overstretch U.S. forces and reduce the flexibility of U.S. foreign policy options by creating a de facto antiCommunist alliance which would be unacceptable to some nations like India and Indonesia, and would cause resentment by excluding others. These objections remained just as valid five months later, and more could be added. A recollection of the political difficulties encountered trying to push the Atlantic Pact through 
Congress made the prospect of a Pacific counterpart, in the current atmosphere of partisan warfare, extremely remote. Nor was the Soviet Union any more likely to participate in a Japanese treaty accompanied by a multilateral anti-Communist alliance as one which featured only a bilateral base agreement, hence the fundamental objection of the JCS to a treaty remained intact.

In early May, Secretary Acheson was scheduled for a trip to London for a series of discussions with U.K. Foreign Secretary Bevin and French Minister of Foreign Affairs Robert Schuman. He had hoped that by the time of the meetings that the State and Defense Department would have resolved their differences over a Japanese Treaty, and be able to so inform his diplomatic counterparts. Yet as of late April the situation was no closer to resolution than it had been in December. Worse, Walton Butterworth, who had begun to work almost exclusively on treaty matters, had come to feel the righteous wrath of the "China Lobby" and as a result would soon assume the distant post of Ambassador to Sweden. One of his last duties before being succeeded by Dean Rusk as Assistant Secretary for Far Eastern Affairs, was to arrange a high level meeting for April 24th, in which the Secretaries of State and Defense and the JCS would attempt, face to face, to thrash out their differences.

From the records of the event, it was one of Acheson's stellar performances, by turns cutting and accomodating. The position confronting the United States, he began, had reached a point where the status quo in Japan could no longer be maintained. The political situation in Japan was rapidly deteriorating and 
subsequent Soviet actions would neither conform to nor be limited by legal niceties. The U.S. could not just do nothing. It must either summon the political courage to put its relations with Japan on a new footing, or be prepared to face even less favorable circumstances as time went on..$^{40}$

This caught the attention of the military men. Secretary Johnson sought to blame the popular agitation in Japan on press reports of the State-Defense dispute, which he attributed to leaks from State Department officials. ${ }^{41}$ Whatever the ultimate source the coverage of the treaty stalemate had been extensive throughout the spring of 1950, and was producing a nationalist backlash in Japan. As of February, an independent poll indicated that 48 percent of all Japanese favored the Socialist policy of "permanent neutrality. ${ }^{142}$ By the end of March, a concerned SCAP Political Advisor William Sebald wrote "the communists are being so successful in crystallizing Japanese public opinion against base rights and against a 'separate' peace, that unless something is done to counteract this propaganda, we may be faced with a hard, hostile public opinion in Japan when these matters are eventually raised at the time of the peace conference. ${ }^{43}$ The rapid growth of antiAmerican feeling had even panicked MacArthur by mid-April. Changing his mind yet again, the SCAP wildly asserted that "95 percent of the Japanese people are opposed to American bases in Japan," that only pressure from the Pentagon had made him agree to their necessity, and that unless the Japanese should undergo a massive change of heart, "the entire proposition [of U.S. bases] should be abandoned." ${ }^{.44}$ 
These were only the latest variations in the political prescriptions of General MacArthur. Generals Collins and Vanderberg both insisted to Acheson that during their February visit MacArthur had confided that it was not a peace treaty he desired, but the proposal for a peace conference by the U.S. which, when followed by the inevitable Soviet refusal, would score a propaganda victory for the United States in Japanese eyes. Secretary Johnson insinuated that "propaganda" for a treaty came not from SCAP, but only from State, but that he and General Bradley would be going to Tokyo in June to sort out the disparities once and for all. In any case, progression towards a treaty was still premature, and would be for at least another six months. By that time, Admiral Sherman felt, Taiwan would have fallen to the mainland, and U.S. Pacific security would need to be reassessed from that vantage. $^{45}$

Acheson wanted to make clear that the State Department did not desire a treaty "for the mere sake of having a peace treaty." But the stubborn adherence to the position that a treaty was premature was inadequate:

...the State Department was not proposing that U.S. forces in Japan be reduced in size, increased or anything of the sort....He emphasized that whatever military requirements were essential to U.S. security were for the U.S. military to determine. If, for example, bases were not enough and it was necessary to have the right to move about in Japan then an attempt would be made to obtain such rights....[however] a point is eventually reached where one has to peg one's military requirements through the conclusion of a new arrangement and one must be willing to pay the price for this. 
Acheson bluntly pointed out that if the deadlock continued, the Soviets would eventually propose a peace conference along the lines suggested by the U.S. in 1947, which the United States could then not refuse to attend. ${ }^{46}$

What the April 24th meeting had managed to emphasize above all else was that just as political pressure in Japan was mounting against the granting of bases, the imperative of their retention in the minds of military planners was also growing, as Japanese bases assumed a vital role as a critical component of U.S. global, not just regional, security. Because of the contingent demands of world-wide containment, the JCS "could not separate the U.S. position in Japan from possible hostilities in Europe," hence, "the defensive and offensive aspects of military operations" could not be easily or clearly distinguished. As the military significance of Japanese bases increased, so could the expected Japanese opposition. Public opinion, as Butterworth pointed out, "would be influenced by whether or not U.S. bases in Japan would act as a magnet to draw upon them the consequences of any military operation. ${ }^{47}$

The Defense representatives agreed that they could move up the timetable of reconsideration, but would need to wait until Johnson and Bradley returned from Japan at the end of June. In the meantime Army Secretary Pace would take up responsibilities for Japanese matters from the obstreperous, intransigent Voorhees. Acheson would have to stall yet again with Bevin and Schuman in May, which would be embarrassing in the case of the long put upon Bevin, but perhaps a relief concerning the French ("the Quai d'Orsay will in one way or another, leak anything 
you say," warned one memo briefing the Secretary).$^{48}$ Yet for the first time in many months a policy rapprochement seemed something other than a distant possibility. In Japan and in Washington, events were already underway which would signal the end of gridlock.

\section{THE IKEDA MISSION}

At a speech before the Diet on January 24, 1950, Prime Minister Yoshida Shigeru enraged his political opposition by asserting that Japan's right of selfdefense was not a hostage of the anti-war Article IX of the Constitution, a sentiment which he borrowed from a MacArthur address delivered New Year's Day. ${ }^{49}$ Opposition stemmed from the belief that the Prime Minister's remarks could be interpreted as a readiness to concede bases. By February, it had become a common item in the press that Yoshida favored an exchange of bases for a security guarantee. Stories even appeared which linked for the first time the political dominance of the conservative parties to close U.S. security ties, Japanese Government officials expressing the hope that the U.S. could not only be relied on to keep the Russians out, but to put down domestic disorders should the Government grow even more unpopular. ${ }^{50}$ But bases were really a secondary consideration, for Yoshida desired a peace treaty above all else, and was well aware, in general terms at the very least, of the dispute which prevented Washington from moving forward. Despite his public statements favoring a comprehensive peace, ${ }^{51}$ a close alliance with the United States under a separate peace was not considered a 
bad thing. As a young diplomat, Yoshida had served as a member of the Japanese delegation to the Versailles Conference, and he was acutely aware, as his opposition was not, that the terms of a separate peace were likely to be much better than one concluded under the auspices of the old allied powers. If bases were the price, Yoshida was at least willing to give the matter serious consideration.

During the spring of 1950, as Socialist and Communist propaganda fomented deepening opposition to military bases and a separate peace, and even SCAP was advocating at the most a token presence of U.S. forces, Yoshida reached the conclusion that if the impasse in Washington was to be broken, he would have to take the initiative. The old difficulty of making Japanese views known directly to Washington again presented itself, but by 1950 SCAP, while still a barrier perhaps, was no longer an insurmountable obstacle.

In some ways, Yoshida's deep suspicion of a Japanese military made his position much easier. Japan's right of self-defense under Article IX did not mean an abandonment of the principles of disarmament and renunciation of war, it only meant that Japan would be free to seek other arrangements beyond "unarmed neutrality." "In the post-treaty period," Yoshida confided in a post-prandial mood to Cloyce K. Huston, an official of the Political Advisor's Office, on the evening of April 7, 1950 (his first documented conversation on security matters), "Japan must rely upon the United States for protection as it will possess no armaments of its own."152 
The Prime Minister had seemingly reserved for the occasion a ripe sense of historical analogy. "When it is objected that Japan will become a colony of the United States," Yoshida waggishly let slip, he always had a ready reply; that "just as the United States was once a colony of Great Britain but is now the stronger of the two, if Japan becomes a colony of the United States, it will also eventually become the stronger!." Then, perhaps sensing that he may have disconcerted his American guest, Yoshida politely deferred, "naturally the United States did not wish Japan to become a colony or a satellite."

The bitterness and humiliation which shadowed the Prime Minister's ferocious ironies were apparently lost upon Huston, as Yoshida hurried on. "He then continued to speak quite volubly," wrote Huston:

...avoiding any specific commitments, but always allowing the inference that he would be favorably disposed toward whatever practical arrangements the United States might consider necessary in order to assist Japan in the maintenance of her security in the posttreaty period. He definitely avoided any flat statement, however, that he would favor American military bases in Japan after the treaty.

Slyly, Yoshida finished his performance by suggesting that the United States was badly misreading the situation in China. The Chinese were too clever and politically astute to be dominated by the Russians. That ancient land would "never become a slave of the Kremlin." ${ }^{53}$ Something more than opportunism may have prompted the Prime Minister; perhaps it was another, hidden analogy.

By the end of April, State Department officials were aware of Yoshida's thinking, though they had had no direct discussions with him. Curiously, it seems to have been the JCS who first broached the idea of direct talks to sound out the 
Japanese leadership on their willingness to consider the granting of U.S. bases, but State officials were cautious about any initiatives which might increase antiAmerican sentiments and strengthen the Prime Minister's large and vocal opposition. ${ }^{54}$ All the while, the Prime Minister was moving forward with plans of his own, which he broached neither to SCAP, nor even to members of the Japanese Foreign Ministry. ${ }^{55}$ His goal was to get the attention of the State Department and the Pentagon, and in this his maneuver, at long last, succeeded admirably.

It was opportunity which dictated Yoshida's choice of instrument. His Finance Minister Ikeda Hayato was schedule to depart for early May discussions with Joseph Dodge in Washington on economic matters. Yoshida entrusted him with his message, but gave his Minister no indication as to whom in Washington it should be relayed, trusting, apparently, to Ikeda's own discretion in the matter. This left Ikeda in something of a quandary, as Miyazawa Kiichi, who made the trip with Ikeda, would later relate:

Finance Minister Ikeda was wondering to whom he should relay the diplomatic message that he had been intrusted with. In the end, he decided that since Dodge was both a representative of the State Department and an adviser to the Department of the Army, neither agency would be offended. On the afternoon of one of his free days [May 2] he called on Dodge at his office. Dodge and his secretary Dr. [Ralph W.E.] Reid (Special Assistant to the Under Secretary of the Army), on their side and Mr. Ikeda and myself on our side faced each other. ${ }^{56}$

Ikeda began by summarizing the political difficulties which the treaty issue was causing the Government. The Socialists and other non-communist opposition groups, which even comprised members of a rival conservative party, the 
Democrats, had formed a "United Front," at the end of April ostensibly aimed at preventing a separate peace and military bases. In actuality, with the exception of the continuing, but seperate efforts of the Communists, the alliance was "construed as an internal political effort" aimed at forming a coalition which would be capable of carrying a no-confidence vote against the Government. Already to this end, a pair of resolutions had been submitted to the Diet favoring an "overall" peace, but they had been defeated. Under the circumstances, Ikeda conveyed to Dodge a most palpable desire for quick action on a treaty: "The present government party prefers the earliest possible treaty with all the interested governments included, but, if this is not possible, wants the other kind of treaty as early as possible." The Liberal Party wanted to remain in power and saw action on a treaty as a necessary means of staying there. Yoshida hazarded the assumption that the United States might also be interested in his government's viability, considering the possible alternatives. The condominium of mutual interest was being explored and established. "Essentially," wrote the plainspoken Dodge, "they want the best they can get under the circumstances and as quickly as possible. ${ }^{157}$

Ikeda explained that much of the domestic ferment was in his view the result of a perceived lack of a firm American commitment. Army Secretary Royall's comments had not been forgotten, and were augmented by a perception that the United States was in the process of abandoning Taiwan and South Korea. The Government, and the citizenry, were likewise disappointed and frustrated at the degree to which SCAP continued to dominate the conduct of political and economic 
affairs. Ikeda then came to the rub, emphasizing that this was a personal message from the Prime Minister, not as yet to be considered as official policy:

...the Government desires the earliest possible treaty. As such a treaty probably would require the maintenance of U.S. forces to secure the treaty terms and for other purposes, if the U.S. Government hesitates to make these conditions, the Japanese Government will try to find a way to offer them.

A study of the constitutional angle has led to the conclusion that if continuing U.S. bases was made a requirement of a treaty it would make such a treaty easier to establish; also, that even volunteering the continuance of these bases would not be a violation of the Japanese Constitution. This provision could be in the treaty itself or by separate agreement. ${ }^{58}$

Yoshida had clearly indicated a readiness to take a gamble on resolving the security issue on a quid pro quo basis. In risking a separate treaty, the Japanese Government was not only ready to accept bases, but to take on an additional political burden by requesting them. But in return, the Japanese Government would thereby make itself into a negotiating partner and active participant to any treaty, not just a defeated party to whom terms would be dictated. Dodge had concluded the meeting with Ikeda by promising what no Japanese official had heard for many years, that the views which he had communicated would "be placed in the hands of proper officials of the Department of State and the Department of the Army." ${ }^{159}$

From this point on, the relations between the two countries would begin slowly to resemble "normal" government to government contacts. On May 3, Yoshida again told members of the Liberal Party that neutrality and an overall peace were an "impossibility"; and in May 8 press conference, he claimed that "an independent peace settlement with the United States has for all practical purposes 
already been established." ${ }^{60}$ On June 1, 1950, the Government released an official White Paper declaring itself willing to accept a separate peace with any nation which desired one. ${ }^{61}$ In the co-mingled rush of necessity and expediency, Yoshida had begun the restoration of his nation's sovereignty by ceding an important component of it to the care of another.

\section{A NEW CAST OF CHARACTERS}

It was more than a week before the transcript of the Ikeda-Dodge meeting was in the hands of the State Department. "The conversation is regarded as significant," Butterworth chimed to Acting Secretary Webb (Acheson then being in London) on May 12, "because it is the first expression we have had on an official level of the attitude of the Japanese Government." ${ }^{62}$ In addition to cabling the Secretary, Butterworth informed Webb that a copy of the memo had been forwarded to the new Consultant to the Secretary of State, John Foster Dulles.

At first Dulles might seem an odd choice to have been serving in an official capacity in a Democratic administration. By 1948, at the very least, when he served as the foreign policy advisor to the presidential campaign of New York Governor Thomas E. Dewey, Dulles was an influential figure in Republican Party politics, commonly regarded as that Party's next Secretary of State when the Republicans next assumed the White House. By that time his experience was already vast. For many years a leading international lawyer, he had served on the reparations commission of the Versailles Conference, as a principle advisor to the San Francisco 
Conference which fashioned the United Nations, and later as a delegate. His long connection to Dewey notwithstanding, Dulles had already performed invaluable service to the Truman Administration's bi-partisan efforts in foreign policy. Appointed by Dewey in 1949 to serve the remaining four months of the term of a resigning Senator, Dulles had worked closely with the Senate Foreign Relations Committee Chairman Arthur Vandenburg, a former isolationist, to convince fellow Republicans to support NATO and the Military Defense Assistance Program. It was not just the loss of the Senate's Democratic majority in the 1948 elections, but the vast and unprecedented scale of the Truman foreign policy's economic and military commitments during peace time, that had made bi-partisanship essential to the passage of Truman's initiatives. Then the goodwill evaporated overnight in the debacle over China.

By that time Dulles was no longer in the Senate, having been defeated in his bid for re-election. In one of his frequent tirades, Defense Secretary Louis Johnson once "characterized Dulles as an impractical man who approached the world's problems with a religious, moral, and pacifistic[!] attitude. ${ }^{163}$ His alleged pacificism aside, the product of Johnson's profound ignorance (for Dulles was a man who truly learned to love the bomb), Dulles' abiding faith in a bi-partisan approach to U.S. foreign policy had indeed grown out of a deeply Christian conviction of the evils of the Communist menace, which at times made Dulles insufferable to many, his views caricatured by his opponents as those of a crusader, a sanctimonious prig. Yet it was the sincerity of his core beliefs, which made, even in an atmosphere of the 
most bitter partisan strife, for enduring convictions. A good part of the Republicans' scathing attacks on the Administration grew from the charge that unlike U.S. policy in Europe, in the Far East bi-partisan consultation had been abandoned. Acheson and Truman realized that if they were to salvage a Far East policy and a Japanese peace in the face of ongoing difficulties with the Pentagon, and anticipated trouble with many nations over the need for a non-punitive treaty, that they could not afford to add to their woes by ignoring this complaint.

Acheson had by then already come to the conclusion that further progress on Japanese matters would require, in his words, "a new cast of characters." Because so many of the State Department men experienced with the problems of East Asia had been tainted by the smears of McCarthy and the China Lobby, the choice would preferably center on someone outside the department who could be charged with the presidential authority to draw up and negotiate the treaty, and then who could be of use getting it through the Senate. ${ }^{64}$ Naturally, this suggested a Republican, and a man of experience and standing; but with partisan passions running so high, who would be willing to take the political risks of serving? Dulles was really the only choice, a man ambitious enough to take up the challenge, and one, still smarting from his campaign defeat, with plenty of free time.

Dulles' appointment was announced by the State Department on April 6, 1950, and was to be effective April 19. Yet at the time, Dulles' specific tasks and duties had not been finalized. But it was also clear that Dulles himself had an interest in the Japanese assignment. 
The day after the announcement, Dulles was given an extensive briefing in New York at his own request by Butterworth and Howard on Japan treaty issues as they stood at that time. During the course of the briefing Dulles opposed the notion of Japanese neutrality, and had "grave doubts" as to the likelihood of gaining Senate approval for a Pacific Pact on the NATO model. But to a more limited type of collective security agreement whereby "Japan would be defended against attack and the participating countries would defend one another against attack by Japan" he was "favorably disposed." As to the need for Japanese bases, Dulles considered them "a technical military problem," yet as to the reasoning behind the JCS position that a treaty was premature, Dulles announced that the military was "highly exaggerating the legal difficulties involved" and that furthermore, they were "none of the concern of the Defense Department." ${ }^{165}$ Remarks which perhaps hint at an additional reason behind his selection. The expert opinions of a highly respected international lawyer would be quite useful to the State Department in its ongoing battle with the Pentagon over the timing of a treaty.

Though at the time his appointment became effective Dulles had still not received his assignment, the die was well cast. Rusk had already urged the Secretary that Dulles' first priority should be made the Japanese treaty, a "subject [which] lends itself to an initial bi-partisan agreement on a matter which has not become a bone of partisan contention." ${ }^{166}$ Dulles personally lobbied the Secretary for the job in a most unambiguous manner:

You'll never get anything done unless you select someone in whom you have confidence, give him a job to do, and then hold him to the 
results. Look at the Japanese Peace Treaty -- the department has been discussing it for years without results. Why don't you give someone one year in which to get action, with the understanding that if he can't do it, he fails? Give him a target and enough authority to get there. ${ }^{67}$

And seemingly to good effect. On May 18, the same day Butterworth was posted to Sweden, Dulles was assigned to handle work on the treaty. John Allison, of the Division of North East Asian Affairs, was selected as his assistant.

Motivations of bureaucratic one-upmanship were not entirely absent from the decision. The same day, as Acheson notes carefully in his memoir, the President told his weekly press conference that the responsibility for a Japanese treaty rested with the State Department as a matter of priority and that he hoped its completion was not far off. "This announcement and the assignment of Dulles to work on the treaty," wrote Acheson, with Kremlinesque nuance, "were not lost on Secretary Johnson, who had just announced that he and General Bradley were to go in June on a thirteen-day inspection of our Pacific bases." What the committed infighter did not share was that when he had first learned of this plan at the April 24 meeting with the JCS, it had caught the wary Secretary by surprise. ${ }^{68}$ Dulles had expressed, as early as his April 7 briefing in New York, a desire to meet with MacArthur at first hand. On May 22, four days after the Dulles announcement, Acting Secretary James Webb spoke with Truman about the possibility of having the new man make the journey to Japan and Korea, and "he agreed that this was desirable." Acheson himself made the announcement on June $7 .^{69}$ The fact that the trips of the two parties were timed to precisely coincide was surely not by coincidence, as Acheson freely admitted: "It seemed to us that Dulles and Allison should make a similar trip 
of their own to serve as a warning that discussion of a peace treaty was no longer 'premature."'70 


\section{NOTES}

1. Dean Acheson, "Crisis in Asia - An Examination of U.S. Policy," The Department of State Bulletin, vol. 22, no. 551 (January 23, 1950), pp. 111-118.

2. Acheson was referring to the then ongoing Chinese-Soviet conclave taking place in Moscow which had begun in December 1949. Stalin had forced a reluctant Mao to accept an independent Mongolia People's Republic under Soviet influence, despite Mao's pledge during the revolution that Mongolia would be once again made part of China. The Soviets were also to retain control of Lushun and Dalian in Manchuria until 1952, after which they would be returned to China. See Spence, pp. 524-525.

3. Acheson, op. cit., pp. 115-116.

4. Spence, p. 527.

5. Acheson, op. cit., p. 116.

6. Senator Hugh Butler of Nebraska, quoted in McCullough, pp. 760-761.

7. Ibid., p. 766.

8. Treaty printed in Max Beloff, Soviet Policy in the Far East, 1944-1951 (London: Oxford University Press, 1953), pp. 260-261.

9. The quote, from the January 24, 1950, issue of Pravda, is cited by George F. Kennan, Memoirs, vol. 2 (Boston: Little, Brown and Company, 1972), p. 42.

10. Ibid., pp. 43-44; U.S. News and World Report, vol. 28, no. 7 (February 17, 1950), pp. 26-27.

11. Beloff, pp. 126-129.

12. In December 1946, the Soviet press had reported that 800,000 Japanese prisoners were at work building the Siberian railway. By April 1950, the USSR claimed that the repatriation of Japanese prisoners was complete, as some 520,000 men had been returned to Japan. The discrepancy led the United States to charge that the Soviets were still holding between 300,000 and 400,000 prisoners, a charge the Soviets denied. See Ibid., p. 129 \& pp. 143-144. 
13. Ibid., pp. 140-141; Igarashi, pp. 340-341.

14. FRUS, 1950, vol. 6 (March 9, 1950), pp. 1141-1142.

15. Walter LaFeber, America, Russia, and the Cold War, 1945-1950, 4th ed. (New York: John Wiley and Sons, 1980), pp. 101-102.

16. Igarashi, p. 341; Nikita Krushchev, Krushchev Remembers, ed. and trans. Strobe Talbot (Boston: Little, Brown and Company, 1970), p. 388.

17. Acheson, Present, p. 431.

18. "NSC-68, A Report to the President Pursuant to the President's Directive of January 31, 1950 (April 7, 1950)," America in Vietnam: A Documentary History, W.A. Williams, Thomas McCormick, Lloyd Gardner and Walter LaFeber, eds. (New York: Anchor Books, 1985), p. 77; Lafeber, pp. 97-100.

19. McCollough, p. 772.

20. Ibid., p. 773.

21. FRUS, p. 1131.

22. Ibid., p. 1115; Acheson, pp. 430-431.

23. FRUS, pp. 1112-1113.

24. Acheson, p. 430. That Voorhees had deliberately misconstrued MacArthur, see the letter written by Political Advisor William Sebald to Assistant Secretary for Far Eastern Affairs Butterworth, in which Sebald states that MacArthur, in his conversation with Voorhees, propounded a view very similar to that conveyed to Jessup, and later, the JCS. FRUS (fn. 14), p. 1112.

25. Ibid., p. 1112 \& p. 1115.

26. Acheson, op. cit.

27. FRUS, pp. 1133-1135 \& p. 1112; "Japan: Costly Base for U.S.," U.S. News and World Report (February 17, 1950), pp. 26-27.

28. Ibid., p. 26.

29. FRUS, p. 1134.

30. Ibid., p. 1133.

31. Acheson, op. cit. 
32. FRUS, p. 1122.

33. Ibid., p. 1118 \& p. 1124.

34. Ibid., p. 1118.

35. The phrase was employed by Legal Advisor Adrian S. Fisher in a memo to the Secretary (January 19, 1950), Ibid., p. 1130.

36. Ibid., p. 1126 (fn. 14); pp. 1130-1131; pp. 1150-1153; pp. 1158-1159.

37. Ibid., pp. 1127-1128; p. 1159.

38. Ibid., pp. 1138-1139.

39. FRUS, 1949, vol. 7 (November 18, 1949), pp. 901-902.

40. FRUS, 1950, vol. 6, pp. 1175-1177.

41. Ibid., p. 1177.

42. U.S. News and World Report (February 17, 1950), p. 27.

43. FRUS, pp. 1154-1155.

44. Ibid., p. 1167 \& p. 1170.

45. Ibid., pp. 1177-1178.

46. Ibid., pp. 1178-1179.

47. Ibid., p. 1181.

48. Ibid. (May 5, 1950), p. 1192.

49. Dunn, p. 92.

50. U.S. News, op. cit.

51. Curtis, p. 42.

52. FRUS, pp. 1166-1167.

53. Ibid.

54. Ibid., p. 1180. 
55. Masumi, p. 192.

56. Ibid.

57. FRUS, pp. 1194-1195.

58. Ibid., pp. 1195-1196 (italics mine).

59. Ibid., pp. 1197-1198.

60. Masumi, pp. 193-194.

61. Dunn, p. 92.

62. Butterworth received the memo on May 10, 1950. FRUS, p. 1198.

63. William J. Sebald with Russell Brines, With MacArthur in Japan: A Personal History of the Occupation (New York: W. W. Norton and Company, 1965), p. 253. Dulles biographical information has been culled from Ronald W. Pruessen, John Foster Dulles: The Road to Power, vol. 1 (New York: The Free Press, 1982) and Dunn, pp. 95-97.

64. Acheson, pp. 431-432.

65. FRUS, pp. 1161-1166.

66. Ibid., p. 1161.

67. John Foster Dulles, War or Peace, (New York: Macmillan, 1953), p. 122.

68. FRUS, p. 1178; Acheson, p. 432.

69. FRUS, p. 1207.

70. Acheson, op. cit. 


\section{CHAPTER VII}

\section{JOHN FOSTER DULLES AND THE IMPACT OF KOREA}

On May 30, 1950, the rising tide of Japanese anti-Occupation, anti-American sentiment spilled over, for the first time, into actual violence against U.S. troops. The occasion was a Communist-organized demonstration, a "People's Rally," and in the melee which ensued one soldier was beaten and stones were hurled at four others. The rally had been called partially to satisfy Cominform critics that the JCP was indeed committed to the new Party line of direct action, and partially in response to statements by MacArthur. In a public address on the occasion of the third anniversary of the Constitution, the General had questioned whether the JCP ought not to be forbidden to operate. In turn, MacArthur had been prompted by secret SCAP reports that the N.K.V.D., the Soviet secret police, had infiltrated the JCP ranks, and that JCP members had engaged in a long list of illegal activities. ${ }^{1}$ Eight Japanese were arrested in the aftermath of the incident, and after trial by a military court were sentenced to imprisonment with hard labor, as a lesson to others that defiance of the Occupation would not be tolerated. But the crackdown would not end there. On June 6, barely a week after the riots, MacArthur resisted the suggestion to outlaw the Party, and instead ordered a purge of all members of the JCP central committee and the editors of the Party newspaper, Akahata. Fearing further reprisals, many members of the JCP went underground. ${ }^{2}$ 
Though it was perhaps rather late in the day to worry, as MacArthur did, that the occupation increasingly exhibited a "complex of entrenched power," in fairness, he had pushed for its end for more than three years. ${ }^{3}$ He had now been forced to embark on a course he had greatly wished to avoid. No one realized more than he that SCAP involvement in acts of domestic political repression, no matter how justified, was a descent down a slippery slope which entailed great risks and no benefits. Even Japanese unsympathetic to the appeals of the JCP were bound to react in a negative, nationalistic way to the sight of foreign troops dispersing and arresting Japanese protesters. It would be the ultimate confirmation, already widely shared, of the occupier's despotic intentions.

The news, when it reached Japan, of the precipitate arrival of the twin missions of Defense Secretary Johnson and General Bradley, and of John Foster Dulles, again raised popular hopes and expectations that a treaty might soon be realized. The recent restiveness, when combined with the good possibility that Japanese hopes might once more be dashed, suggested the possible onset of a politically explosive situation, causing MacArthur to plunge afresh into a renewed effort to find a solution to the conundrums of Japan's future security, and quickly, before Washington's intransigence threatened to destroy his great achievement.

In the long memorandum prepared in anticipation of the arrival of his distinguished guests, MacArthur made much of his most current pre-occupations. Communist propaganda had seized upon the wide press coverage of the longstanding State-Defense impasse to assert that the U.S. was out to "colonize" 
Japan and make war upon the mainland, and this was making his life difficult. Nor were the security arrangements most recently to find favor in Washington much to his liking. The "stand-by" SCAP arrangement favored by the Pentagon was too transparently obvious and unacceptable a limitation on Japanese sovereignty. But collective security, as envisaged by the State Department, "could not now fail to be interpreted as dictated by primary American security requirements -- with accent upon the defense of the United States rather than the defense of Japan," and hence, also unlikely to enlist much support from the locals. Rearmament was still out of the question for the usual medley of reasons: indigenous pacificism, economic difficulties, fear and loathing in the rest of Asia. MacArthur's favorite scheme had developed a new and unusual twist however; Japanese neutrality could somehow be reconciled, in an unexplained way, with a continued access to "military and naval bases and other available facilities adequate to meet the needs of our security operations." ${ }^{14}$

Yet amidst the rehash of old proposals and discredited approaches, appeared one idea with a future, a revelation that behind the General's bludgeoning ego lay a mind capable of considerable subtleties. MacArthur had long maintained that the Japanese were entitled to a peace treaty because they had honorably fulfilled the conditions of the Potsdam Declaration, namely, disarmament and the elimination of military influence from Japanese political life. By the terms of Potsdam, at such time as these objectives were accomplished (along with the election of a "responsible" government), the Occupation would be withdrawn. But now 
MacArthur turned and gave special note to the Wilsonian phrase at the end of Article VI: " ...we insist that a new order of peace, security and justice will be impossible until irresponsible militarism is driven from the world." Given a narrow interpretation that phrase might refer only to Japanese militarism, MacArthur argued, but it could certainly support a much broader one, though for present purposes directed at a certain party unintended by the framers. ${ }^{5}$ Hoping to satisfy both State and Defense, MacArthur proposed:

That a normal treaty be consummated embodying, however, a security reservation to the effect that so long as "irresponsible militarism" exists in the world as a threat to "peace, security and justice" in Japan, the pertinent conditions of the Potsdam Declaration shall be deemed unfulfilled and, in view of the attendant threat to unarmed [Japan]...points in Japanese territory [shall] continue to be garrisoned by the Allied Powers...through United States forces....

At about the same time, in distant Washington, John Foster Dulles was feeling his way through the issues as he plotted his own agenda. The more he looked at the problem, the more he found geographical, historical, economic and cultural factors weighed against the prospect of a post-treaty Japan willing for long to side with the western camp. "Can there be found," he asked, "outside of the Communized areas, adequate sources of raw materials and markets for Japanese industry so that Japan's economy can be reasonably...prosperous without dangerous dependence either on Communist controlled areas or large United States grants of aid?" In developing a social portrait of the Japanese people, Dulles cobbled together a long list of stereotypes: an alleged tendency to authoritarian rule; a lack of religious faith which could protect the individual against the pressures of social 
conformity; institutions which promote the interests of the family, the group, and the nation; an emotionalism which currently sympathized with pacificism, but which "could easily shift to a revival of militarism," only to wonder if such a people could ever find common ground with the nations of the west. The best chance in light of the obstacles, Dulles concluded in a most telling and unfortunate manner, would be to play upon the Japanese sense of status and racial insecurity, much as if the United States held out the possibility of membership in a snobbish, elite Connecticut country club:

There is a certain barrier with the West in the face of the assumed Western sense of white superiority. But there is a sense of superiority too, and, in some respects, to the Chinese and a desire to be treated as social equals by the West....It may be that the principle attraction to hold Japan in the Free World will be capitalizing on their desire to be an equal member of the family of free nations, a concept obviously not consistent with the subservience to the Kremlin inherent in the Communist world. ${ }^{7}$

The days prior to his departure were devoted to a mulling over with Allison the security options to be broached with MacArthur. Dulles knew that style would be as important as substance. While in Germany years before, Dulles had noted the tendency of the head of American Occupation forces, General Lucius Clay, to judge all recommendations on the basis of whether they would be favored by the Germans, a phenomenon Dulles called "localitis." He strongly suspected that MacArthur suffered from the same affliction. ${ }^{8}$ On the eve of his journey, Dulles was more concerned whether the JCS desired Japan as major staging area for offensive air strikes: "That decision, if adopted as U.S. policy, would have many consequences in terms of relations with, and responsibilities for, the Japanese." And 
what of U.S. policy towards Taiwan and South Korea "and the impression given Japanese and Russians as to our will to stand fast in these environs of Japan[?]" The envoy left with more questions than answers.

Dulles and his entourage landed at Tokyo's Haneda airport in the early morning of June 17, 1950, only hours ahead of the plane which carried Secretary Johnson and General Bradley towards the same destination. Two hours later, Dulles was back on a plane bound for South Korea, for four days of meetings with Korean officials and President Rhee, before a scheduled return to Japan. The next day, a Sunday, just north of the town of Uijongbu, Dulles posed for a famous photograph -- standing in a trench surrounded by South Korean officers and U.S. military advisors, binoculars raised to scan the expanse of the 38th Parallel. ${ }^{10}$

On the morning of June 22, the day after the latter's return from Korea, MacArthur disclosed to Dulles the earlier compromise proposal he had worked out based upon the language of the Potsdam Declaration. Dulles suggested he elaborate upon them, and present them the next day. There was an apparent recognition between the two men that much of the impediments which had blocked progress towards a treaty lay in an inappropriate use of language. The term "bases" was a word which had for Japanese sensitivities an unmistakably colonial ring, compounded by a host of other disagreeable connotations derived from another era -- such as long leases, extraterritoriality, and the spoils of conquest. The term conveyed to the Japanese the unsavory prospect of becoming another of the United 
State's Pacific appendages, like the forlorn Philippines. The very idea of "bases" would have to be thankfully abandoned.

MacArthur took up his task with a vengeance. "The concept that the defense of a land area necessitates only reservation of pre-determined points for air, ground and naval concentrations has been outmoded," he wrote with Strangelovian relish, "in place thereof, the entire land mass must be regarded as a potential area for maneuver." What this meant for Japan, the General did not mince words:

The entire area of Japan must be regarded as a potential base for defensive maneuver with unrestricted freedom reserved to the United States as the protecting power through her local commander, acting in the normal chain of command to the Department of Defense...and in the event of hostilities to take such tactical dispositions as the situation may from time to time require. ${ }^{11}$

Instead of bases, the United States would henceforward respectfully request that the Japanese Government provide "facilities."

Certainly the General's conception went a long ways towards addressing the requirements of the Department of Defense. They did not wish to be confined to "bases" any more than the Japanese relished the prospect of being forced to grant them. Indeed, apparently unaware that Dulles had not only been shown the memo but had been intimately involved with its drafting, Secretary Johnson and General Bradley, who must have been given their copy of the proposal only hours before their departure on June 23, were so pleased with its contents that, like a pair of comic villains, their intent was to squirrel it away to be produced later to the embarrassment of the State Department. ${ }^{12}$ 
Yet it is to be wondered whether the Japanese, who at best considered bases as a necessary evil, were to find a situation where U.S. military forces had the run of the entire country as any real improvement, or whether the Japanese man or woman in the street was capable of appreciating the legal distinctions. In an effort to make it all more palatable, the General offered the stipulation that except in the case of "hostilities or imminently threatened hostilities" no large disposition of forces would be undertaken without consultations with the Japanese Government. U.S. forces would not intervene in Japan's internal affairs. As opposed to leases, economic inducements were to be offered in the form of a "pay as you go" arrangement which promised to pump an annual $\$ 300$ million into a still grievously ailing Japanese economy. In the view of its principle architect, there should be no constitutional difficulties either; for in the case of hostile attack Japan's right of defense was "inalienable." And Dulles offered the final suggestion that security arrangements be couched in the language of "overall international peace and security rather than in terms of any special advantage to the United States at the expense of Japan." ${ }^{13}$ Though at the time of the discussions between the Dulles and the General the policy differences which separated the Pentagon and the State Department remained stubbornly in place, by the end of their two days of talks a formula had been reached around which disagreements would later crumble. The outline of what would become the future security treaty between the United States and Japan had taken on a recognizable shape, which even the events of the next few momentous days would not appreciably alter. If anything, the onset of war only 
stiffened Dulles' resolve to plunge ahead. "It has always been a weakness of United States policy," Dulles wrote to Secretary Acheson upon his return to Washington, "that when war breaks out we abandon political aims and concentrate wholly upon military aims." ${ }^{14}$

If talks with MacArthur had achieved something of a breakthrough, Dulles' many discussions with Japanese leaders did not go nearly so well. He did not, of course, divulge the contents of his recent palaver with MacArthur; his many interviews with Japanese officials and members of opposition parties, when they touched upon delicate security matters, were conducted at a more general level. Dulles' assessment was nonetheless bleak: "[W]e came away from Japan with the definite impression of a confused and uncertain people. There was little evidence that the Japanese had thought through the significance of their position in the world of today."15

The clear message was one of wanting to be left alone. The Japanese did not like the occupation, and they wanted their independence. Dulles encountered variations on two sets of opinions. "Most of the Japanese with whom we talked," he noted sourly, held the unrealistic hope "that Japan's renunciation of war and armed force...would make it possible for Japan to remain apart from the struggles and dangers of the rest of the world." Others, those who had given thought to security problems, believed Japan should "continue to be protected by the United States, preferably from long range." Dulles was told that if the U.S. did not protect Japan, the country would have to look elsewhere, "and there was the clear implication that 
the only way to look was toward Moscow." But isolationism and pacifism stopped at the borders. The preoccupation with domestic subversion which so obsessed the anxious leaders of pre-war Japan had been inherited by their postwar progeny. The inability of the Japanese police "to deal with internal troubles without the backing of American armed forces was one which was common in almost all circles in Japan," with the significant exception of SCAP officialdom. ${ }^{16}$

The most aggravating and disturbing encounter was reserved for Prime Minister Yoshida. Dulles had been scheduled for a discreet "get acquainted" rendezvous with Yoshida at the home of William Sebald on June 22. When the pair arrived, Sebald's residence was surrounded by "at least a hundred reporters, cameramen and hangers-on....we agreed that the prime minister's public relations men were on the job." The meeting was a disaster. Sebald observed with embarrassment that Yoshida was in a "puckish mood"; all smiles, he spoke "with circumlocutory indirectness, with vagueness, and with an astute use of parables."17

This did not endear him to Dulles, who wanted a serious discussion on security issues. Yoshida, Dulles later recounted:

...implied that satisfactory arrangements could be concluded, but he could not be tied down as to exactly what he meant. He talked at some length in a rather academic manner about how the nations of the Free World would come to the aid of Japan, if Japan would prove it had learned the lesson of the war and was firmly attached to democratic principles. ${ }^{18}$

The Prime Minister implied that the United States should see to his country's security needs, but that "Japan's amour propre must be preserved."19 
Dulles was "flabbergasted." He wanted to know what Japan intended to do to provide for its own security; but reciprocity of the type Dulles envisaged was not a concept with which the Prime Minister was forthcoming. When the Consultant pressed the desirability of Japanese rearmament, Yoshida protested. ${ }^{20}$ "There was no apparent realization," Dulles wrote, in language which rankled with dismay, though composed weeks after the encounter, "that it would take more than good intentions to protect Japan, and there was a reluctance, in the face of prodding, to admit that Japan would have to contribute its share in some form or another."21 After the meeting an angry, frustrated Dulles confessed to Sebald that he felt like "Alice in Wonderland." 22 Dulles brought up the matter of Yoshida's recalcitrance with MacArthur, but the General backed the Prime Minister, suggesting that the U.S. might look instead to refurbishing Japan's long decrepit military factories, an idea to which Dulles, most reluctantly, agreed. ${ }^{23}$ At the end of three days of meetings, the envoy had attained decidedly mixed results. He then left Tokyo Friday afternoon, June 23, for a placid weekend with his wife in Kyoto.

When he returned to the capital Sunday evening the world had been turned upside down. On June 25, 1950, nearly 100,000 soldiers of the North Korean People's Army, arrayed in armored columns led by Soviet-made T-34 tanks delivered over the course of the previous months, ${ }^{24}$ smashed across the 38th Parallel in a stunning and desperate bid to unify the country by force of arms. The assault came as a major surprise to those in Tokyo, and in Washington, even though for several weeks U.S. intelligence had reported the North Koreans were pulling 
back civilians and concentrating their forces along the border. ${ }^{25}$ John Allison's account of the Dulles Mission's last three days in Tokyo unintentionally peels away the claustrophobic world of a dissipated occupying class disrupted only briefly from their endless embassy parties and drinking rituals for furtive, huddled crisis meetings: a boozy-woozy black comedy of panic, dread, mock heroics and selfdeceit. $^{26}$

At the center of it all was MacArthur, whose behavior reveals the terrible depths of his isolation and delusion, as the crisis cascaded from bad to worse. On the evening of the 25th, a Sunday, MacArthur chose to characterize the assault as a "reconnaissance force." "If only Washington will not hobble me," he bellowed as he paced his office, intermittently pulling on the trademark corncob pipe, "I can handle it with one arm tied behind my back." ${ }^{27}$ The next evening, as news that the fall of Seoul was imminent, MacArthur remained uninformed because his aides feared disturbing him while he enjoyed the ritual of his nightly motion picture. ${ }^{28}$ Tuesday morning, a despondent MacArthur accompanied Dulles to the airport to see him off. When told that he must return to Tokyo for a conference with Secretary of the Army Frank Pace, MacArthur refused: Dulles' plane had been delayed because of mechanical difficulties. Dulles, Allison and Sebald had to stage a mock boarding onto the still grounded plane before MacArthur would depart. ${ }^{29}$ The message which awaited him was Truman's authorization for U.S. air and naval power to be used in defense of the South, and the dispatch of the Seventh Fleet to the Strait of Formosa. On his return to Washington, Dulles, despite his public veneration of the 
man, had found MacArthur's actions so dismaying that he privately urged Truman to retire the seventy-year old General before he caused a calamity. ${ }^{30}$

\section{"SAVED"}

"Korea came along and saved us," said Dean Acheson, an odd, cryptic remark for a Secretary of State, ${ }^{31}$ but it is easy to see what he meant. The war was confirmation of a world view that men like Acheson had long propounded to reluctant world leaders and domestic critics alike, one that held as its defining core an unscrupulous adversary willing to resort to brutal and aggressive means to advance its goal of global domination. Others had been understandably reluctant to embrace such a vision of the world because of the sacrifices inherently entailed in meeting an evil defined in such stark, unqualified terms. Such qualms were now quashed before the evidence. NSC-68 had lain dormant on Truman's desk; but no more. At a momentous July 14 Cabinet session, Acheson advocated in the strongest terms for a vastly expanded military establishment, and Truman agreed. An administration which had spent years pruning the Pentagon was now committed to lavish spending. On July 19, 1950, in a special message to Congress, the President requested $\$ 10$ billion in emergency military appropriations, nearly doubling the Defense budget of $\$ 13$ billion. For fiscal year 1950-51, Defense spending would climb to $\$ 48$ billion, and for the next year Congress would appropriate $\$ 60$ billion. ${ }^{32}$ Korea not only finalized the United State's commitment to the cold war, but to the manner in which it would be waged. For decades to come the political 
struggle with the Communist world would be conducted through the permanent and perpetual mobilization of the country for total war.

If Korea did not save U.S. policy in Japan, it went a long way towards obliterating the remaining obstacles to it. In the weeks and months to follow a rough consensus would emerge and opposition melt away, whether from the Pentagon, the domestic critics of U.S. Far Eastern policy, and most significantly amongst the Japanese themselves. Like nothing else could, the war bound the two countries uncomfortably but inextricably together, deepening the American commitment to the relationship, and hastening the Japanese one: politically, economically, militarily.

To the mind of John Foster Dulles, the news of the North Korean invasion had one immediate salubrious effect: it split Japan's domestic opposition and public opinion. "There was more open admission than had been previously been obtained for the continuing need for United States military forces," he noted approvingly, and cited the about face of a Japanese newspaper that was now in favor of U.S. bases. ${ }^{33}$ If Dulles ever feared that the war would further build neutralist sentiment in favor of an understanding with a belligerent Soviet power, it did not last long. On his last day in Japan, Tomabechi Yoshizo, Chairman of the conservative Democratic Party, which had earlier joined the JSP in a coalition against bases and a separate peace, told Dulles that the newspapers had greatly exaggerated his party's position. Tomabechi said that an overall peace was, of course, desirable, but that his party would be willing to proceed without the Soviets, if necessary. ${ }^{34}$ 
But Dulles was not a man to let matters drift. The war had awakened the Japanese from their "postwar stupor," he told Acheson, "and I think that their mood for a long time to come may be determined by whether we take advantage of this awakening to bring them an insight into the possibilities of the free world and their responsibility as a member of it." Failure to do so might prove catastrophic, Dulles grimly admonished, "we may lose in Japan more than we can gain in Korea." ${ }^{35}$ A good part of Japan's responsibilities, Dulles and other U.S. officials were certain, lay in aiding the war effort.

\section{A GIFT OF THE GODS}

Prime Minister Yoshida had been uncharacteristically silent for the first week of the war. When the invasion began, he had been on vacation at a country home on the slopes of Mt. Hakone, southwest of Tokyo, and when reporters converged upon him for a statement, he made none. Nearly three weeks would pass before he made his views public, on July 14 , at the opening of a new session of the Diet, and much had transpired by then. ${ }^{36}$

The first week of July, some 30,000 vastly unprepared and inadequately armed U.S. troops were sent from garrison duties in Japan to fight a rear guard action against the North Korean blitzkrieg in the wretched monsoons of the Korean summer. Many more would soon follow. The swift departure of so much of the occupation force would leave an undermanned and under equipped Japanese police with the responsibility of safeguarding Japan's domestic stability alone under 
volatile and uncertain circumstances. The horrendous implications of Communistinspired insurrection in Japan while the United States was fighting a war in Korea disturbed both MacArthur and Japanese leaders.

MacArthur responded on two fronts. The purge of the JCP, which was begun on June 6, was now expanded. Communists were summarily expelled from jobs in broadcasting and on the staffs of newspapers, and from positions in strategic industries: steel, ship-building, mining and energy sectors. Then, on July 8, necessity intervened where years of Washington's (not to mention Japanese) prodding and pleading had been to no avail. MacArthur, in a letter to the Prime Minister, ordered the rapid formation of a National Police Reserve of 75,000 men, and an augmentation of the Maritime Safety Board (the Japanese coast guard) by an additional 8,000 men. The internal organization and command structure of the new force would be separate from the civilian police, and would be equipped by the United States with "small arms": carbines, tear gas, and submachine guns. ${ }^{37}$

Often in the past, the Japanese Government had been lethargic, when not obstructionist when implementing SCAP directives, but not this time. Wrote Yoshida, "The necessary steps to implement these decisions were to be taken by the Japanese Government without delay," and he was not especially unhappy about complying. Considering the weaponry at its disposal, the military value of the police reserve, even in a defensive capacity was almost negligible, but potent enough to insure domestic security in a manner which would not be too politically troublesome. Nevertheless, the military implications of the new force were plain 
enough, and in no time, critics of the Prime Minister were charging that the Police Reserve was the first part of Yoshida's plan for Japanese rearmament. Yoshida's truthful assertions that the reserve was for internal security purposes only, did not convince everyone. Within one month, on August 10, 1950, the National Police Reserve had come into being. ${ }^{38}$

Standing before the Diet on July 14, the Prime Minister carefully spelled out the government's position on the war. Japan could not directly participate in UN military actions in Korea, but would cooperate with that effort to the extent that Japan's circumstances would permit. "The evil hand of the red invader is approaching Japan," he sternly advised, and because of the war all hopes of an overall peace and neutrality must be forsaken in the interest of preserving domestic order and Japan's democracy, which would only be secured in the future by aligning Japan to the free nations and the principles of the UN Charter. To that end, Yoshida vowed that his Government would vigorously suppress movements to discredit the UN and its operations in connection with the war effort, and any attempts to stir anti-American sentiments. ${ }^{39}$

Though now broken, Yoshida's long public silence had been in pointed contrast to private deeds. Here, as at other times, the influence of the past provided clues for the course of the Prime Minister's actions. Even if it was not a position which he could safely announce publicly, Yoshida was enough of a diplomat of the old imperial school to believe with axiomatic faith that Japan's vital interests lay in preventing the fall of South Korea into the grasp of a hostile foreign power. So 
while Yoshida had publicly announced that Japan would assist the UN, very few were aware of the extent to which the Prime Minister was prepared to cooperate. On July 4, four days before MacArthur would request the creation of the police reserve, Yoshida informed his Cabinet of his desire to facilitate the war effort in a manner well beyond what propriety and discretion might have advised..$^{40}$

It was a curious position to be in. Yoshida, better than almost any man, could appreciate the irony that the monumental task which now fell upon the sixteen-nation UN Unified Command, led by the United States, was nothing less than the defense of the historic frontier of the late Japanese empire. Japan's overriding interest in Korea's security had been the catalyst of a half-century of imperial expansion, an enterprise whose unhappy conclusion necessitated the current peculiar arrangements. Japan's interest remained, but the job of fighting would have to belong to others. Yoshida needed no coaxing to realize Japanese troops would be an impossible contribution: for even had his own constraints and inclinations been otherwise, the Korean memory of their former overlords was too bitter to ever permit their re-introduction.

But there were other, more or less indirect ways, for Japan to make a contribution to its own defense, as Yoshida clearly realized. Military operations in Korea would require a large and complex logistical web of supports: supply depots, airfields, ports, hospitals, training facilities and communications. All these were gladly supplied. ${ }^{41}$ Japanese shipping was freed up for the massive build-up of men and material which poured for several months into the Pusan perimeter at the 
southern tip of the Korean peninsula where the advance of the NKPA was finally halted. ${ }^{42}$ At Inchon, nearly a third of MacArthur's 120 transport vessels were Japanese $^{43}$; and between October and December 1950, the U.S. Navy allowed the use of Japanese minesweepers along the Korean coast. ${ }^{44}$ Secretly, the Japanese Government made available to UN command the expert advice of many of the industrialists and engineers who had built Korea's harbors and railroads when the country had been a Japanese colony. ${ }^{45}$

Still in effect at the war's outset, the Dodge stabilization program, which had brought Japan to the brink of depression, was quickly abandoned. But even in its debilitated condition, Japan's economic contribution to the war effort was profound. It was also proof, if proof were needed, of the strategic value of Japan's industrial potential. It reinforced the belief, already prevalent in Washington, that that potential must be firmly and permanently bound to the west. And like nothing else, the war provided the opportunity to forge the necessary links to do just that. In retrospect, Yoshida was to call the Korean conflict "a gift from the Gods, ${ }^{146}$ a somewhat insensitive, if genuine acknowledgement of the importance of the war for spurring Japan's postwar economic recovery.

Less than a month before the outbreak of hostilities, the Department of Defense had begun inquiries regarding the possibility of utilizing Japanese industry for the production of "non-armament items" to be transferred to eligible countries under the Mutual Defense Assistance Program (MDAP), but concern over violating FEC directives, and the sensitivities of recipient countries weighed against the 
idea. ${ }^{47}$ Under the exigencies of war, scruples gave way. On July 19, 1950, the State Department concluded that "loopholes" in FEC policy, if given a generous interpretation, "might confer upon General MacArthur not only authority to allow Japanese industry to supply civilian-type items for military end-use but to permit the mobilization of Japanese armament industries for the same objective."48 By August, in addition to production for Korea, State had approved the procurement under MDAP for "trucks, radios and other normal peace-time goods....[and] the utilization of Japanese facilities in the repair of ships or airplanes." ${ }^{\prime 49}$ The thrust of these efforts was made unmistakably plain by Secretary Acheson in a memo of December 13, 1950, after the war in Korea had taken a decided turn for the worse. There would need to be, he wrote:

A basic economic decision on the part of the United States to assure the economic survival of Japan without dependence upon Communist mainland areas. This would require access by Japan to food and raw materials and the foreign exchange wherewith to pay for them. To this end the United States should be prepared, if necessary, to put our military garrisons in Japan on a "pay-as-you-go basis and, presumably, substantial orders for military equipment would be placed in Japan under MDAP.

The Korean war thereby cemented one of the most enduring characteristics of the complex dynamic evolving between the two countries. Japan's strategic economic ends would be secured and served by United States military means.

For the war did more than breath new life into Japan's moribund industrial economy, it laid the groundwork for its future spectacular expansion. Between July 1950 and February 1951, by way of example, the United States ordered over 7,000 trucks from Japanese plants at a cost of over $\$ 13$ million, "the key," in the words of 
one expert on Japan's economy, "to the revival of the Japanese automobile industry. ${ }^{150}$ Over the same period, over $\$ 200$ million in goods and services were purchased by the UN in connection with the war effort. ${ }^{51}$ The result was a "procurement boom" which rippled across the entire economy. Though the "boom" collapsed at war's end, bringing on a period of renewed hardships, hidden benefits would continue to accrue. War-time procurement, and the foreign exchange it earned, had all been overseen by guiding hand of the Ministry of International Trade and Industry. The windfall thus gained and protected, would be released for productive investment in basic industries; and in an economy of chronic capital shortages this bureaucratic discretion conferred tremendous power, which would in turn profoundly influence the structure of the Japanese economy for decades to come. $^{52}$

Yet even as the war was refashioning and binding the interests to the two countries closer together, issues of peace and security continued to lay unresolved. During the months of August and September 1950, Prime Minister Yoshida played a double game of sorts in an attempt to resolve the domestic and diplomatic dilemmas that the war, if it had not caused them, had made more delicate and precarious. The attainment of a peace treaty as quickly as possible continued to be his foremost concern, for his political future was intimately tied to its realization, but hostilities on the Korean peninsula obviously complicated the prospects. The occupation, though one denuded by the deployment of military assets at the front, threatened to linger on indefinitely if Washington became preoccupied with the war 
to the exclusion of all else. On the other hand, the war had sliced through the gordian knot of security issues by rendering them moot. Because he had no intention of rectifying his country's military weakness, as long as the threat to Korea remained a palpable one, Yoshida recognized the twin realities that Japan's security demanded a continued U.S. presence, and now more than ever, the Americans, as a condition of any negotiations, would insist upon it. The job before him lay clearly in getting the best deal that he could.

The Prime Minister, with a certain impish zest, was not above reminding forgetful Washington of his existence and of his needs in ways calculated to get their attention. Answering questions before the Upper House Foreign Affairs Committee of the Diet on July 29, Yoshida informed his interlocutors, though carefully hedged with many a hypothetical speculation, that he was personally opposed to leasing bases to any foreign country, and that furthermore his Government had received no such request, which was certainly true. The "Allied powers do not intend to present such a demand," he continued, "as it is the desire of the Allied powers to keep Japan out of war." That this was intended for more than domestic consumption is confirmed by the visit paid by Vice Minister of Foreign Affairs Ohta to Political Advisor Sebald, informing him that Yoshida's statements were to be considered some of the "most important made to date" by the Prime Minister. ${ }^{53}$

When forwarded to Washington the news caused a bit of a stir. "It is difficult to determine what Yoshida had in mind," wrote the worried officer in charge of the 
Japanese desk at the State Department, who characterized the statements as "curious" and "mystifying": Didn't he realize Japan was imperiled by "the Red invasion[?]" On the face of it, Yoshida's remarks, at the very least, seemed a reversal of the position conveyed by Minister Ikeda in May. Rusk, Allison, and Kennan all requested further clarification. Sebald at least, seems to have seen through the ploy. Had U.S. garrisons not been fortuitously stationed in Japan, a defense of South Korea could not even have been attempted. After such a demonstration of its immense utility, Japanese real estate had simply appreciated in strategic value:

Japanese leader must be fully aware of this fact, and it would be logical for the Japanese (who have never hesitated to play power politics on a grand scale) to intimate that the price for these allimportant bases in Japan is greater than the US perhaps reckoned. Certainly the Japanese are in a position to refuse a treaty imposing any disabilities on Japan. They are also in a position to seek -- and to obtain -- treaty terms recognizing Japan's right to self-defense. Because acceptance of US bases is the price Japan knows she must pay for an early treaty, Mr. Yoshida is probably prepared to accept them for a defined short period of time, provided the other treaty terms and supplementary concessions (such as economic aid) are adequate. $^{54}$

While tweaking U.S. noses may have had its moments of amusement, much of the Prime Minister's time was spent quietly building domestic support for the kind of peace and security terms he hoped to negotiate when the time arose. What he wished to avoid at all costs was to be the founder of a Japanese Wiemar Republic, where the taint of capitulation would eventually undermine popular support for the regime. Through the summer of 1950, Yoshida engaged in highly confidential discussions with financial and business interests on one hand, and with 
former officers of the Imperial armed forces on the other. ${ }^{55}$ Prepared for all contingencies, should disaster strike in the form of U.S. defeat and withdrawal from Korea (and possibly even Japan), Yoshida explained that he was prepared to accept Japanese neutrality; otherwise, he hoped to negotiate lenient peace terms with the United States, then sign a security pact as a first exercise of Japan's restored sovereignty -- the specific terms under which U.S. forces would remain in Japan would be clearly spelled out in a separate document. ${ }^{56}$ Like Dulles, the Prime Minister wanted the security arrangements worded in accord with the lofty principled rhetoric of the UN Charter, as a concession to a public opinion that would have to be groomed to accept the idea of a post-treaty U.S. military presence, rather than an explicit military alliance. But it was soon plain that partisan strife would not be easily confined to the pacifist intransigence of the left. When former Prime Minister and conservative Democratic Party rival Ashida Hitoshi's declared that Japan's Constitution did not prevent rearmament for the purpose of selfdefense, Yoshida, as head of the Liberal Party, interpreted the remarks as a rather bald attempt to curry favor with Washington at his political expense. ${ }^{57}$

\section{THE END OF AN IMPASSE}

If that indeed was Ashida's intention, it was not a bad stand for an opposition politician to take. The war and his own recent unsatisfactory experiences in Japan made Dulles something of an enthusiast on the topic of Japanese rearmament; nor was he the only one in Washington whose mind was moving along similar martial 
lines. During July 1950 , suggestions emanating from various recesses of both the State and Defense Departments ran the gamut from the mild -- beefing up of the Police Reserve beyond the 75,000 already approved by MacArthur -- to the extreme. Dulles' favorite scheme, which he dutifully relayed to Paul Nitze, the Director of Policy Planning, called for the recruitment of Japanese on an individual basis, organizing them into units, and then placing them at the disposal of UN Commanders for service in Korea. ${ }^{58}$

It was an attempt to somehow get around an inconvenient roadblock that all who confronted the problem were forced to acknowledge: the inherited vestige of the Potsdam Declaration, and the subsequent decrees derived from it that forbade, in quite explicit restrictive language, all attempts to reintroduce military or paramilitary institutions on to Japanese soil. Hoisted by their own petard, this legacy had been roundly supported when its ostensible aim had been imposing inhibitions on the resurrection of a congenitally militaristic people; it was quite another when it was Washington, rather than the Japanese themselves, that wished to do the rearming, and that now found the imbedded idealism of an earlier time a hinderance, rather than a blessing. Indeed, much of Dulles' passion to conclude a treaty as quickly as possible derived from the anticipation of ending restrictions on Japanese rearmament once and for all. Of course, this did not oblige the U.S. to do nothing in the meanwhile; though efforts would need to be conducted "quietly and gradually" for fear of hazarding "Soviet action of a preventive charactcr":

At best there would be some risk of this, but subject to furthor study it would seem that this risk was less than the risk of perpetuating an 
indefensible position as regards this area which is one of those which may constitute the decisive balance of strength between the communist world and the free world. ${ }^{59}$

Subterfuge and bureaucratic double-speak would be called in to remedy the situation. An unsigned Policy Planning memo of July 26, 1950, concluded, apparently in accord with Dulles, that the United States, in the interest of national security, must not allow itself to become mired in legal niceties and obligations, if what was at stake was the very survival of the free world. If the United States could not act legally, it would act illegally, but in a good cause. The brief memo was thus, in more ways than one, a harbinger. The graphic enunciation of a new American commitment to Japanese rearmament in blatant disregard of Japanese sympathies, the anxieties of allies, and solemn international commitments, reveals a burgeoning hubris lodged within the immensity of American power.

"Heretofore," waxed the anonymous scribe, "the Staff has not pressed for the immediate re-militarization of Japan. ${ }^{160}$ But there had been envisaged, along with the signing of a treaty and the drawing down of the occupation, the inauguration of a military force, limited and defensive in character and mission. Japan's sovereignty entitled it to no less, but in recognition of other constraints there was the realization that this force would not, by itself, be able to stem "direct aggression by a great power." Its conception was supplemental, an adjunct to the anticipated retention of U.S. forces; a gesture of Japanese good faith, by way of a contribution, to the men and treasure the United States was expending to protect the country from the red 
foe. War on the mainland of Asia forced the United States to reevaluate this orderly timetable of events:

The Korean conflict and the deep uncertainties regarding the future now make it imperative, in the opinion of the Staff, that we proceed forthwith to create Japanese forces designed to contribute to the defense of the islands. We realize that there are many serious impediments to the implementation of this objective....At the same time we must recognize that all peoples of good will, including the Japanese, are through no fault of their own confronted with a new situation radically different from that envisaged in the Potsdam Proclamation and the Post-Surrender Policy. On this basis we are justified in resorting to extraordinary measures to enable Japan to contribute to its own defense. ${ }^{61}$

Those extraordinary measures were left purposefully vague, although Dulles' earlier suggestion was one which was deemed worthy of more study. Implicitly, the United States would oblige, and if need be compel, the Japanese to a fuller understanding of their own best interests.

Curiously and revealingly, although the United States Government had by the end of July reached a hasty consensus as to the desirability of bringing about the secret rearmament of Japan, the tiresome squabble between the State Department and the Pentagon over the security provisions to be negotiated into a Japanese peace treaty continued to make progress there elusive, even in the face of Presidential urging. ${ }^{62}$ The dogged Dulles had nonetheless been hard at work, and on July 27, informed Acheson that he believed he had achieved a draft which would even please Louis Johnson: "They [the prospective articles] are designed to give, in a form as inoffensive as possible to the Japanese, the broad power in the United States to place military forces wherever in Japan the United States may determine 
to be desirable from the standpoint of international peace and security in the Japan area." ${ }^{.63}$

Yet Dulles' attempts to garner Johnson's reaction met with an irritable stonewalling. Johnson "had a war on and didn't have time to talk" about Japanese matters, and furthermore, Dulles' proposals did not meet the criteria of the JCS, who had come to a secret understanding with MacArthur to which the State Department was not privy. But Dulles was indeed privy and so informed Johnson. The Defense Secretary promised to give the proposal a closer study, but as his mind was as subtle as an armored division, he found Dulles' diplomatic finesse troublingly vague. $^{64}$

The essence of diplomacy, as Dulles knew, was what was left unsaid. Had Johnson and his military associates been a little less thick they might have realized that Dulles was handing them Japan carte blanches right in the middle of draft Article II: "Japan requests and the United States agrees that it will provide such armed forces on behalf of the Treaty Powers, and the Japanese Government on its part shall provide such assistance and facilities, including rights of passage, as may be determined by the United States in consultation with the Japanese Government." ${ }^{455}$ To those in the State Department, the meanings were all too clear. Dulles' draft "appears to favor the conclusion of a peace treaty per se regardless of the political consequences of the military blank check we ask of Japan as its price," bemoaned one official, "It is not sufficient merely to have the phrase 'Japan requests' buried in the midst of a treaty. The request should be of a formal 
and unmistakable character."166 After further study, and some "heated" dialogue within the NSC, Johnson and the JCS nonetheless rejected the Dulles draft because they found it unclear and prone to misunderstanding. ${ }^{67}$

Still, the men at the Pentagon were finding it increasingly difficult to adhere to their myopic rejection of every State Department proposal in the face of political pressures building within the administration, aided by importunities from influential allies, pushing for some resolution to the security issues which had impeded progress towards a treaty for nearly a year. At the same time the salience of those very issues, because of the war, had risen exponentially, an oddly fortuitous turn of events which offered the Pentagon the prospect of getting much more than it otherwise might have hoped. In the overall interest and indispensability of a "friendly sovereign Japan," the JCS, by the end of August, were magnanimously prepared to drop their contention that the Soviets and the Chinese Communists be parties to any treaty. But the Chiefs' assent to allowing negotiations to go forward was highly conditional.

U.S. military assets had already been applied dangerously thin before Korea. ${ }^{68}$ The war on the peninsula made matters worse, both in the material logistical difficulties of deploying adequate manpower while maintaining strength in other areas, notably western Europe, but also because of the unavoidable swelling of commitments to resist communism that the war implied, particularly in the rest of Asia. The question which gnawed at military planners was weighing whether what was happening in Korea was but the opening gambit in a much larger Kremlin plan. 
It was in light of these factors that the JCS was prepared to deal. There were three demands: 1) Japan must eventually be rearmed for "effective self-defense," since the United States, neither under the UN nor unilaterally, had sufficient resources to meet its other responsibilities and simultaneously defend a completely unarmed Japan; 2) in the event of global conflict Japan's "war potential" must be available to the United States; 3 ) though negotiations could proceed, no treaty of peace must be ratified before a "favorable resolution" had been achieved in Korea ${ }^{69}$

Except for some minor reservations about the Chiefs' choice of language, the State Department unhesitatingly agreed. Many of the assumptions, with the exception of the proviso with regards to the Korean War, which was readily assented to ${ }^{70}$ had been implicit in the draft security articles which Dulles had so painstakingly crafted. The diplomats had to keep reminding the generals that an excess of literal-mindedness was seldom advantageous: some highly desirable, and attainable things, like access to Japan's "war potential," human and industrial, should not be spelled out "so that the Treaty will look to the Japanese and to the world as little as possible like a grab for power on the part of the United States," ${ }^{71}$ which of course, by unstated implication, it would be.

On September 7, 1950, Acheson and Johnson forwarded to President Truman for his approval a joint memorandum which declared in effect that something like a truce had been finally achieved. The details had been worked out over the course of a week by John Allison and General Magruder, the language in which the approved security formula had been adumbrated was "brutally frank," a 
concession, wrote one State official, "...to the military's desire to avoid any possibility of future misunderstanding within the U.S. Government as to the terms of the agreement reached. Public disclosure of a document so phrased could be disastrous to the whole treaty project. ${ }^{.72}$ Such apprehensions were quite justified, for in addition to the considerations listed above the agreement provided that a treaty must not deny Japan the right of self-defense; that the size, the length of stay, location and ultimate withdrawal of forces would be at the sole discretion of the United States; foreign forces unacceptable to the U.S. would be forbidden from Japanese territory; and, at the request of the Japanese Government, U.S. forces could be used to "put down large-scale internal riots and disturbances." ${ }^{73}$ Such terms were unlikely to prove acceptable to Japanese public opinion, or initially, to any Japanese or allied government. Yet there seemed to be small doubt that the United States would have its will in the end.

The next day, September 8, Truman approved the memo, though other matters were most definitely foremost on his mind. Four days later Secretary of Defense Louis Johnson was forced to resign, a move which Truman had actively contemplated since early July. Johnson's replacement, former Secretary of State, General George Marshall, was nominated the same day. ${ }^{74}$ On September 14, Truman, at a press conference, announced that the United States would begin preliminary negotiations with nations at war with Japan willing to conclude a treaty according to a series of suggested terms privately circulated by the U.S. (initially amongst the eleven members of the FEC). Since one of those terms envisaged 
"continuing cooperative responsibility" between the United States and Japan in matters of security, it was plain that the U.S. was going to proceed without the Soviets. ${ }^{75}$ The next day, Dulles declared publicly that future U.S. bases in Japan would not be used for staging offensive operations against the Asian mainland, nor would any treaty impose restrictions on Japanese rearmament. ${ }^{76}$ Had differing circumstances prevailed, these rather surprising public statements might have received more attention and scrutiny; it is quite probable that the timing was well thought out and deliberate. On the other side of the world, at the very moment the President was speaking to Washington reporters, General MacArthur and 70,000 men were attempting, at a place called Inchon, one of the most daring amphibious assaults in the history of warfare.

\section{DESPAIR}

The final months of 1950 were a time that began with euphoria and ended in despair. By October 1, UN forces had retaken the whole of South Korea, and they had done it in only two weeks. Only days before, Defense Secretary Marshall told MacArthur to "feel unhampered tactically and strategically," and MacArthur responded: "I regard all of Korea open for military operations." ${ }^{\text {77 }}$ Even U.S. policy towards the Japanese seemed to partake for the moment of the national mood -incautious, exultant, overbearing. The first Department of Defense draft of the U.S.- Japan Bilateral Security Agreement advanced the following:

No land, sea, or air forces will be established by the Japanese government during the period this agreement is in effect, except with 
the advice and consent of the United States government with respect to the strength, type, composition, armament, and other organizational features of such forces, any schedule for their creation being in all respects subject to the determination of the United States government in consultation with the Japanese Government. ${ }^{78}$

Japanese forces would, in time of war, be under U.S. command, and could not engage in combat beyond Japanese soil, unless ordered by the U.S.-appointed Supreme Commander. Such terms were "unnecessary and provocative," in MacArthur's unhappy view, and the United States was sowing the seeds for "destructive appeals to national sentiment."79 Dean Rusk reached the panglossian conclusion that the "peremptory and demanding" document was one "not best calculated to promote that attitude of friendly cooperation...and the hoped for enduring association of Japan with the free world," a task made more complicated "due to the sweeping nature of the military rights which it has been decided that the United States should seek in post-treaty Japan." ${ }^{180}$

Regrettably, behind the facade of U.S. security demands there frequently lurked racial hatreds and fears fixed by a history of conflict and deeply held beliefs in the inferiority and untrustworthiness of "orientals." These in turn undoubtedly informed the incessant need exhibited time and again to exact and inflict, by a seeming force of habit, subservience, humiliation, and most of all control. But the political psychology of domination is ofttimes predicated precariously upon the uncertain outcome of events that have no obligation to conform to prejudice or expectations. On November 24, 1950, a quarter of a million Chinese soldiers crossed the Yalu River, beginning the longest, and one of the most desperate, 
retreats in American military history. By December 2, the White House was facing the possibility of a complete evacuation of the peninsula, an "American Dunkirk," in the words of one historian. ${ }^{81}$ The gloom and recriminations engendered by the appearance of catastrophic defeat altered in the most astonishing way some fundamental questions, and an arrogant demeanor was replaced by one of cringing anguish and confusion. Overnight, the considerations of U.S. policy makers had changed from one of how to get the Japanese to accept onerous conditions, to what price must the U.S. be willing to pay to secure Japan's continued goodwill. An odd and uncomfortable reversal of roles had taken place, but one which left many old assumptions intact.

To the panicked Dulles, Japan's prospective ties with the United States would be unlike those of the Atlantic allies where affinities of shared history and culture provided the basis of lasting political bonds. The Japanese decision he informed Acheson, either for or against, would be made solely upon unsentimental calculations of perceived power and advantage:

...recent developments in Korea make it doubtful whether Japan can be relied upon to form a dependable part of the non-communist world....There should be a prompt effort definitely to commit Japan, spiritually and politically, to the cause of the free world....The United States still possesses prestige in Japan and the full political and military implications of the Korean defeat are not yet apparent....[Yet] a survey may disclose that there is no reasonable chance of success...If Japan is willing on certain terms to accept commitment to our cause, then these terms should be ascertained to see whether the price is practical and worth paying. ${ }^{82}$

Acheson passed these thoughts, with some embellishments of his own, to Secretary of Defense Marshall. The Soviets, with the aid of the Chinese 
Communists and the North Koreans were "moving to dominate Asia," and their "principal objective" was Japan. The Japanese could be expected to crumble to communist pressures unless the United States pledged itself utterly to Japan's military and economic survival. As preliminary moves Acheson suggested that the U.S. proceed on the peace treaty without waiting for the increasingly remote chance of a favorable outcome in Korea, and urged the dispatch of a Presidential mission to ascertain "the terms upon which Japan could be brought into the orbit of the free world. ${ }^{183}$

The Joint Chiefs soon made their own preferences clear: now was certainly not the time for concession or capitulation. The military assessment was hardened, pitiless. Faced with the prospect of escalation to global war, Japan, bereft of U.S. forces called by MacArthur to the Korean front, lay defenseless and vulnerable to Soviet attack, "a military vacuum." Any negotiations undertaken with the Japanese under the prevailing circumstances would be conducted by the United States from a position of "extreme weakness," the JCS concluded, forcing the U.S. to undertake formal commitments to Japan's defense which the United States could not readily honor under conditions of world war, and which would be used by the Japanese as a pretext for not providing for their own security. Furthermore, in a profound misunderstanding of the real nature of Japan's security interests, the Pentagon asserted that a Japan restored to full sovereignty could be expected to "deprive United States forces of the use of Japan as the major base of operations in the Korean war." The diplomats had it all wrong. By way of grotesque analogy, the 
Chiefs argued that U.S. interests dictated not a Japan as free and willing ally, but the creation of the most odious kind of Japanese puppet state:

The Soviet Control Commission has, through overt and covert means, adjusted its controls over East Germany to further the objectives of the USSR, while at the same time providing East Germany most of the benefits which would be expected to be derived from a peace treaty....The Joint Chiefs of Staff consider that comparable measures could be taken in Japan without coercion, and to the satisfaction of the Japanese people.

First among the covert measures to be undertaken under the new regime would be immediate rearmament and the amendment of the Japanese Constitution. ${ }^{84}$

The views of the JCS at the end of 1950 provoke the most intense and disturbing sorts of questions about the Government of the United States, and its relationship with the rest of the world. It is to be wondered whether the Chiefs really considered the manner in which the Soviets imposed their will in that contented East Germany they held up as their ideal, and whether that particular example was one that was in America's interest to emulate: at the very least, if the United States did not have the necessary troops to defend Japan, it was certainly odd that the Chiefs seemed to hold that similar numbers would be readily available to do the work of turning Japan into an American stockade. Though it lies purely within the realm of speculation, it might be said that at the close of 1950 , had the course of events conspired a different way, that the United States was very close to endorsing policies that might have led to the "loss" of Japan, a country which much more so than China was America's to lose. 


\section{NOTES}

1. Igarashi, pp. 341-342. FRUS, 1950, vol. 6 (June 15, 1950), pp. 1221-1222. SCAP had reason to believe that the JCP was unaware of the N.K.V.D. presence in their ranks.

2. Igarashi, p. 342 .

3. FRUS (June 14, 1950), p. 1213.

4. Ibid., p. 1220.

5. Ibid., p. 1218.

6. Ibid., p. 1221.

7. Ibid. (June 6, 1950), pp. 1208-1209.

8. Ibid., p. 1165.

9. Ibid. (June 15, 1950), pp. 1222-1223.

10. John Allison, Ambassador from the Prairie: or Allison Wonderland (Boston: Houghton Mifflin, 1973), p. 127.

11. FRUS, p. 1227.

12. I could not discover whether Johnson or Bradley actually discussed the memo with MacArthur, but it is certain they did not discuss the matter with Dulles. Though the Tokyo sojourn of both parties overlapped between the 21st and the 23rd, no record of a meeting exists. William Sebald goes so far as to admit that if a meeting took place he was unaware of it. But by circumstantial references it is certain that Johnson and Dulles did meet at some undetermined date, and that Japanese security was a topic, possibly (mere speculation on my part) the prospects for Japanese rearmament. See Ibid. (fn. 1), pp. 1228-1229 \& pp. 1259-1260.

13. Ibid., p. 1228 \& p. 1230 . Dulles even suggested that Japanese military "facilities" be made available, not to the U.S., but to the Security Council of the United Nations.

14. Ibid. (July 19, 1950), pp. 1243-1244.

15. Ibid. (July 3, 1950), p. 1231. 
16. Ibid., pp. 1232-1235.

17. Sebald, p. 257.

18. FRUS, p. 1232.

19. Sebald, p. 257.

20. Yoshida, p. 265.

21. FRUS, p. 1232.

22. Sebald, p. 257.

23. Dower, p. 383.

24. LaFeber, p. 103.

25. Brigadier General Crump Garvin told John Allison that he had seen the reports and that "anyone...could see something was going to happen and soon. I don't know what G-2 [Government Section of SCAP] in Tokyo has been doing." Allison, p. 131.

26. I do not think I exaggerate my characterization of these events, particularly the frequent references to heavy consumption of alcohol. Allison, pp. 126-139.

27. Ibid., p. 129.

28. Ibid., p. 135.

29. Ibid., pp. 137-138.

30. McCullough, p. 793.

31. LaFeber, p. 100.

32. McCullough, pp. 791-792.

33. An editorial for the newspaper Jiji Shimpo, dated June 26, read: "...And if Japan wants herself defended by the United States, she should voluntarily offer the strategic parts of her territory as American military bases." FRUS, p. 1231.

34. Ibid., p. 1234.

35. Ibid., p. 1243.

36. Kondo Shigekatsu, "Japanese Response to the Korean War," The Occupation of Japan: The Impact of the Korean War, p. 9. 
37. Under a host of FEC directives, to which the U.S. was a party, weapons available to Japanese police forces were limited to "small arms." See FRUS (July 19,1950), pp. 1244-1245.

38. Yoshida, pp. 182-183; Weinstein, pp. 50-51.

39. Kondo, pp. 9-10. On August 19, 1950, the Japanese Foreign Ministry issued an official pamphlet which reiterated and embellished much of the contents of Yoshida's Diet address.

40. Ibid., p. 9.

41. Weinstein, pp. 51-52. Even UN Headquarters for Korean Operations remained in Japan until 1957, when it was moved to Seoul.

42. Sebald, p. 199.

43. Ibid.

44. Auer, pp. 64-67; Kondo, p. 9. Between October 2 and December 15, 1950, over forty Japanese mine sweeping operations took place, mostly from the ports of Inchon and Wosan. One Japanese sailor was killed and eight were injured.

45. Weinstein (fn. 24), p. 51.

46. Dower, p. 316.

47. On June 9, 1950. See FRUS (August 15, 1950), pp. 1275-1276.

48. The Soviet Union had boycotted the FEC since January 1950 over the refusal of the body to seat the PRC. Ibid., pp. 1244-1246.

49. Ibid., pp. 1275-1276.

50. Johnson, p. 200.

51. FRUS, 1951, vol. 6 (February 10, 1951), p. 876. The items include "motor vehicles, weapons and equipment, ship charters, stevedoring, rail transportation, lease of telephone and cable lines and common labor."

52. Johnson, pp. 200-205. Among other things, Johnson shows how MITI's control of foreign exchange earnings decisively influenced the organization of Japanese banking and capital markets.

53. FRUS, 1950, vol. 6 (August 2, 1950), pp. 1262-1264. 
54. Ibid.

55. Weinstein, pp. 53-55.

56. Ibid.

57. Ibid. (fn. 31), p. 54.

58. FRUS (July 20, 1950), pp. 1246-1248. As early as July 6, Secretary of the Army Frank Pace was considering bringing the issue of Japanese rearmament before the NSC. Ibid. (fn. 1), p. 1244. A lengthy memo for strengthening the Japanese police was composed by John Allison and Major General Magruder on July 24, which followed one composed by George Kennan to Dean Rusk of July 18. See Ibid., pp. 1250-1254 and p. 1256, respectively.

59. Ibid., p. 1248.

60. Ibid., p. 1256.

61. Ibid., pp. 1256-1257 [italics mine].

62. Ibid. (July 24, 1950), p. 1255.

63. Ibid., p. 1259.

64. Ibid. (August 3, 1950), pp. 1264-1265.

65. Ibid. (July 25, 1950), p. 1260.

66. Ibid. (July 26, 1950), pp. 1257-1259.

67. Ibid. (August 21, 1950), p. 1276.

68. At the outbreak of the Korean War, the U.S. Army had only 10 divisions. McCullough, p. 789.

69. FRUS (August 22, 1950), pp. 1278-1282.

70. While Acheson agreed to this limitation, Dulles had some misgivings. Ibid. (fn. 1), p. 1293.

71. Ibid. (August 23, 1950), p. 1284.

72. Ibid. (September 14, 1950), p. 1304. The official was U. Alexis Johnson, Deputy Director of the Office of North East Asian Affairs.

73. Ibid., p. 1294. 
74. McCullough, pp. $792-793$ \& p. 798.

75. Dunn, p. 107. The envisaged peace terms, other than those regarding security, proposed a waiver of all reparations claims, eventual UN membership for Japan, a recognition of Korean independence by Japan, a renunciation of special rights and interests in China, U.S. control under UN trusteeship of the Ryukyu and Bonin Islands, among others. They were not made public until November 24, when the Soviet Union published its response to a matter the U.S. hoped could remain confidential. See Department of State Bulletin, vol. 23, no. 596 (December 4, 1950), p. 881.

76. Sebald, p. 259; Dunn, p. 108.

77. McCullough, p. 799.

78. FRUS (October 30, 1950), p. 1341.

79. Ibid. (November 11, 1950), p. 1345.

80. Ibid. (December 13, 1950), p. 1368.

81. McCullough, pp. 824-825.

82. FRUS (December 8, 1950), p. 1359.

83. Ibid. (December 13, 1950), pp. 1364-1365.

84. The document I quote from, JCS 2180/2 -- United States Policy Toward Japan (December 28, 1950), is one of the most astonishing of the Korean War era, and perhaps of the cold war. See Ibid., pp. 1385-1392. 


\section{CHAPTER VIII}

\section{THE AMBIGUITY OF COMPROMISE}

In anticipation of further discussion with the United States, Prime Minister Yoshida, in the waning months of 1950, appointed Nishimura Kumao, head of the Foreign Ministry's Treaty Bureau, to draft a security treaty along lines originally propounded in the 1948 Ashida Memorandum, intending thereby to satisfy the domestic opposition, and it was hoped, the Americans. The Japanese were as yet unaware that the U.S. had abandoned the concept of "bases": Yoshida told Nishimura that he wanted the terms of the base leasing arrangements dressed up in a "silk hat," that is rendered as palatably as possible. In exchange for this concession Yoshida wanted a binding security guarantee. ${ }^{1}$

By November, Nishimura had completed a first draft. It proposed a form of collective self-defense against external aggression in cooperation with the United States under Article 51 of the UN Charter; a joint committee of "consultation and cooperation" between the two countries on security matters; and stationing of U.S. forces for an initial period of fifteen years. ${ }^{2}$ The whole was premised upon Japan's remaining in a demilitarized state, but able to address its own internal security needs without assistance. On this Yoshida was adamant. Aware that there would be strong U.S. pressure exerted for Japanese rearmament, the Prime Minister wanted a negotiating strategy that was prepared counter it: "We are going to 
negotiate a peace treaty on a basis of non-rearmament," he pledged, "Because of this it might be necessary to attach an idealistic plan of anti-weaponry or armament restriction and start out by proposing that 'this is our plan."'13 Subsequent drafts and position statements prepared through December and January in preparation of the scheduled Dulles talks reflected this overriding priority, while stressing the extent to which the Government was prepared to support all other aspects of U.S. policy. ${ }^{4}$ Yet there was, as Yoshida's comments hint, more than a passing element of disingenuousness to this elaborate charade. All the while the impossibility of rearmament was being strenuously asserted, informal, highly secret discussions had been taking place since October 1950 that belie the Prime Minister's pacifist protestations. Led by Nomura Kichisaburo, former Admiral of the Japanese Imperial Navy, a "private plan" for Japanese rearmament was completed by the end of January 1951. The core of the Nomura blueprint was a 200,000 man army and 50,000 man navy-air force equipped with 200,000 tons of shipping and 700 aircraft. The plan was but the first of a series of similar outlines vouched in the early months of 1951 by groups with ties to former Japanese officers, Japanese government officials, and U.S. occupation authorities. ${ }^{5}$ It would be however, a far more modest proposal that was readied in reserve to counter the much expected objections of Ambassador Dulles to the Japanese approach to security affairs. 


\section{ENDGAME}

The situation on the ground in Korea continued bleak. "The Japanese people and their leaders are coming increasingly to feel the danger of throwing in their lot with us in view of the fact that Communist power seems to be closing in upon them," Dulles told Acheson in early January, the very day that MacArthur was warning of Hokkaido's vulnerability to Soviet assault. By the second week in January the JCS and a distraught, increasingly unstable MacArthur had informed Truman that the options left open were withdrawal or resort to nuclear weapons against China, but Truman refused to seriously consider either. Fortuitously as it turned out. Within days, under the leadership of General Matthew Ridgway, the 8th Army halted its retreat and went on the offensive, thereby averting disaster and bringing the most dangerous period of the war to a close. ${ }^{6}$

At the same time, Dulles was preparing for a not dissimilar offensive of his own. The naming of George Marshall as Defense Secretary was already having a most discernable effect. Over the objections of the Joint Chiefs, Marshall agreed with Acheson that the U.S. must seek "an early conclusion of a peace settlement with Japan without awaiting a favorable outcome of the situation in Korea," and had to make the best deal it could with the Japanese under the prevailing circumstances. To no surprise, Dulles was chosen to head the mission on January 10, 1951, with talks scheduled for Tokyo at the end of the month. ${ }^{7}$

As Special Representative of the President with the rank of Ambassador, Dulles was granted authority to negotiate a treaty under the principles embodied in 
the Joint State-Defense Memorandum of September 7, 1950. His instructions from the President, in the unlikely case he needed reminding, urged him to recall that the "United States will commit substantial armed forces to the defense of the island chain of which Japan forms a part," that Japan should be pushed to rearm for its own defense as soon as possible, and that the U.S. was prepared to sponsor a Pacific Pact to the extent that other nations agreed to conclude a peace treaty in accordance with U.S. desires. ${ }^{8}$

Dulles threw himself into his new assignment and the preparations for his forthcoming trip to Tokyo with his usual overabundance of energy. It was economic matters which seemed foremost on his mind, particularly the need to find Japanese markets somewhere other than China. Immediately after his appointment he was on Capitol Hill explaining his mission, in somewhat parochial terms, to the House Foreign Affairs and Senate Foreign Relations Committees, arguing among other things, the need for a non-communist Southeast Asia lest Japan become a permanent drain on the Treasury. ${ }^{9}$ Worried that Japan was becoming overly dependent on U.S. military procurement, he exerted commitments from the Office of Defense Mobilization to insure a generous supply of iron ore and coking coal for the Japanese economy. ${ }^{10}$

By the time Dulles and his entourage arrived in Tokyo on January 25, 1951, he seemed determined to publicly woo Japanese opinion. The keynote was struck during an address to the American-Japan Society on February 2:

Japan, if it is disposed to protect itself against indirect aggression, can, if it wishes, share collective protection against direct aggression. That, 
however, is not a choice which the United States is going to impose upon Japan. It is an invitation. The choice must be Japan's own choice. The United States is not interested in slavish conduct. That is the stock-in-trade of the Communist world. We are concerned only with the brave and the free....the United States would sympathetically consider the retention of United States armed forces in and about Japan, as a testimony to the unity between our countries. ${ }^{11}$

And by the time he left, the structure of the ensuing peace negotiations had been agreed in principle. There would be a multilateral peace treaty, a bilateral security treaty and an administrative agreement negotiated on a mutual basis which would spell out the rights and obligations of the two sides as regards to the stationing of U.S. forces, subject only to executive rather than legislative approval.

But in private discussions with the Japanese leadership on security arrangements, Dulles was far from mannerly. There was by this time ready agreement on the stationing of U.S. forces in post-treaty Japan, yet beyond this concession to unavoidable and uncomfortable political realities there lay a gulf of understandings and expectations. The sessions quickly took on an unpleasant tone.

It was the precise meaning of the collective security that both desired which swiftly rent the two sides. At the outset of the negotiations with the Prime Minister it was very clear that Dulles had every intention of offering the Japanese security arrangements comparable to those extended to the European allies, and that he had no reason to suppose that the Japanese side would not enthusiastically embrace the offer. Those agreements had been concluded upon the basis of sovereign equality, mutual assistance, and an understanding of the interests and obligations of all parties in maintaining regional security. The United States would seek a similar 
understanding with Japan. To that end the United States would be willing to station its forces in Japan to aid in Japan's defense, but in exchange for this, the United States would expect Japan to rearm to a sufficient level to allow it to assume the primary burden of its own defense and to participate at some later date in regional security arrangements with other Pacific nations. What Dulles had in mind was a firm commitment that within a few years of the restoration of Japan's sovereignty the country would have fielded a force of 300,000 to 350,000 -- sizable enough to fend off a major Soviet assault. ${ }^{12}$ The United States would take the lead in dealing with truculent or suspicious allies, as it had done with Germany, and if such a force was incompatible with Japan's Constitution (Dulles didn't necessarily think so), the Japanese must openly see to its amendment. Dulles wanted a Japan aligned with the U.S. that was a fully sovereign, responsible power that could be dealt with like any other ally. Dulles would take the Japanese response to his offer as a bitter, personal disappointment.

At the first meeting between the Ambassador and the Prime Minister on January 29, Dulles was ready to discuss just these sorts of specifics, but Yoshida was unresponsive and elliptical, engaging in another "puff ball performance," as Dulles would characterize it afterwards. ${ }^{13}$ But Yoshida made it quite plain that Japan could not participate in collective security if it meant rearmament; but to usual bevy of economic and political considerations, he added vividly, yet another:

...any precipitate rearmament would bring back the Japanese militarists who had now gone "underground" and might expose the State to the danger of again being dominated by the military. $\mathrm{Mr}$. Yoshida said that it would be necessary to adopt legislation which 
would ensure that the military could not take over the Government as in the past and that other steps should be taken to avoid the dangers inherent in the recreation of a military class. ${ }^{14}$

It is difficult to determine whether the motivation for this remark was but another arrow in the Yoshida quiver intended to deter the Americans by raising the bogey man of the Japanese past. It may have been in part, but there is reason to believe that it came from a deeper source of genuine concern, for Yoshida around this time mentions his fear with some frequency. ${ }^{15}$ Years later, John Allison, who noted the above statement, recorded another after he had become Ambassador to Japan, and hence in a position to speak to Yoshida frequently about military affairs. Questioning Yoshida about whether his distrust might have been excessive or misplaced in the context of the "new" postwar Japan and its civilian restraints on the military, Yoshida responded, "Yes, but they have the guns, haven't they?"16

It was a witty response, but it masked a very real problem, for Yoshida's anxious qualms were the result of more than the mistreatment he had once received at soldier's hands; they were informed by an apprehension, nurtured by long experience, about the nature of political authority within his own society. It should never be forgotten that Yoshida began his career not as a politician, but as a bureaucrat within a ministry, and was thus well acquainted with the tremendous, very nearly sovereign power afforded these organs of the state under the Japanese political system, where the function of the Diet is more often to ratify the decisions of jealous and independent bureaucracies, than it is to legislate and oversee their workings. ${ }^{17}$ Under such a system, the wording of the Japanese Constitution not 
withstanding, a Defense Ministry would enjoy vast prerogatives, yet would, in effect, be answerable to no one, and bound, sooner or later, to become deeply enmeshed in politics. Not only Yoshida, but other powerful interests and institutions with a stake in the prevailing system, like the Ministry of Finance, viewed the creation of such an entity with foreboding, because of its latent power to disrupt, or even upend, the politically conservative but economically motivated and driven society that Yoshida's years as Prime Minister would in large part be devoted to creating. Those elements of Japan's right-wing which were joining Washington's chorus for more rapid rearmament did not necessarily share the Prime Minister's pro-western geopolitical affiliation and political sympathies. ${ }^{18}$

There is little evidence that Dulles, for his part, had much of a grasp of the more subtle realities of Japanese politics, especially when weighed in his mind against the far more concrete menaces offered by Chinese and Soviet divisions. The Ambassador listened to Yoshida's equivocations with some sympathy but with growing perturbation, before pointedly inquiring "whether the Premier was taking the position that the dangers mentioned constituted a reason for doing nothing or merely a recognition of obstacles to be overcome." To achieve the goal of security in the present state of the world meant that there must be sacrifices:

...and that it was necessary for all who expected to benefit by such a system to make contributions in accordance with their own means and abilities. No one would expect the Japanese contribution at present to be large but it was felt that Japan should be willing to make at least a token contribution and commitment to a general cause of collective security. ${ }^{19}$ 
To this appeal, Yoshida made no definite answer, beyond a seeming willingness to take under consideration the type of "contribution" that Japan would be prepared to make.

Within days Dulles had his answer. On January 31, Yoshida submitted a preliminary statement outlining his "personal views": Japan was "eager to play a positive role" in defense of the free world, but the nature of its contribution would have to be circumscribed to providing for its own internal security by augmenting its police and coast guard. The United States would provide external security through the stationing of its troops in Japan; but rearmament in the foreseeable future was "impossible. ${ }^{120}$ In the hope of driving this point home, Yoshida surreptitiously made contact, through his son-in-law, with prominent Socialist leaders urging them to hold conferences and rallies in opposition to rearmament over the course of Dulles' stay. ${ }^{21}$

This minimalist interpretation of Japan's permissible contributions was given further embellishment in a statement issued in response to the submission by the Dulles party of a preliminary U.S. draft of a security treaty. Confirming the Prime Minister's earlier positions, the statement went much further in delimiting the role that Japan could be expected to play, and what it desired in return. The Japanese side explicitly refused to undertake a binding commitment, either presently or in the future, towards rearmament in any contemplated security treaty. Though agreement was later reached that Japanese cooperation would entail allowing UN forces the use of Japanese facilities should operations in Korea, as now seemed 
likely, continue into the post-treaty period, ${ }^{22}$ such would be the extent of Japanese involvement. For just as Japan was unable to provide for its external security, it must not be expected to make a military commitment to regional security beyond its borders. $^{23}$

The extent of Japan's "sacrifices" for the cause of the free world were thus essentially three. Japan would protect itself against internal subversion; it would allow U.S. forces to be stationed on its soil; and it would allow the continued use of the country as a staging area for Korea operations, a concession by which it was profiting handsomely. There was even a bonus, a sop of sorts, tossed in as a tribute to Dulles' intransigence, as Yoshida himself explained:

...we could not discuss the treaty with Mr. Dulles without committing ourselves to some effort to reinforce our defensive power, and as we were invited to indicate some plan representing at least a first step in that direction, we outlined to him a project, long under consideration, for increasing both our land and sea forces and placing them under the control of an embryo Ministry of Defense. ${ }^{24}$

In exchange for these vague verbal promises and limited allowances, the Japanese side desired the United States to assume responsibility for Japan's security by way of formal pledges recognizing the security of Japan as "inseparable" from that of the United States, a security guarantee more encompassing than the terms of the NATO pact. $^{25}$

Taken together, the Japanese response to the American proposals amounted to a declaration. Japan's national interests lay in the preservation of its fragile domestic political arrangements and in furthering its economic priorities. As a consequence of those interests, and captive to their insular and narrow definition, 
Japan could offer only the most ambivalent commitment to the United States' global strategy of communist containment. Such a daring opt out of the overriding foreign policy pursuit of its ostensible benefactor was premised upon a cold assessment of Japan's strategic value to the United States: their country's importance would allow them the privilege of protection while enjoying the prerogative of being left alone.

Yoshida and his advisors got it only half right. They had good reason to fear American zealotry backed by awesome military might, but recognized only its potential for embroiling Japan in conflicts they fervently wished to avoid; conflicts that, at the very least, might have cost them their political careers, hence a consideration of mutual interest, in light of the alternatives, that they wished to impress upon the Americans. But what the Japanese failed to grasp was any real sense of the underlying urgency of the ideological motivations of the other side. The defense of the free world, to which Dulles referred so monotonously, was not mere cant, but an expression of dedication to the preservation of transcendent values to which the very existence of the United States as a nation depended, and was utterly committed: commitments not so dissimilar in effect to the ones that not long before had led the Japanese to fight and die for their emperor. It was all but impossible for the Japanese to share these assumptions, of course; but it was an unfortunate miscalculation that the Japanese side came in effect to spurn them. Because it sealed the postwar future. An affluent and a prosperous future, to be sure, but 
parochial and subservient, and not only to the United States, but to a domestic status quo built upon political evasions and institutional irresponsibilities.

The Japanese position on rearmament obliterated, in Dulles' view, any chance of a partnership of equals. His uncompromising stand, as he reiterated frequently to Yoshida and his aides, was not just a product of his own convictions, but the result of U.S. law. Passed by the Senate in June 1948 as a prelude to the NATO treaty, the language of the Vandenburg Resolution specified "regional and other collective arrangements as are based on continuous and effective self-help and mutual aid," as the fundamental, indispensable condition which would undergird United States participation. ${ }^{26}$ Shorn of its diplomatic allusiveness the wording of the Resolution meant concrete military commitments, and Dulles informed his hosts that the Senate would refuse to ratify any treaty that called upon the U.S. to extend pledges that were not backed by "reciprocal undertakings." Speaking bluntly, he sternly admonished that "the United States will not give a free ride to anybody."27

"Until Japan is in a position to undertake corresponding obligations of its own the U.S. would want rights rather than obligations," Dulles told his staff on the morning of February 5, "The U.S. cannot press the Japanese to assume military obligations until they have dealt with their Constitutional problem and are in a position formally and publicly to assume such obligations. ${ }^{28}$ The United States, under these circumstances, would in no way guarantee Japan's security. Any security agreement, Dulles emphasized, would have to be from the U.S. vantage highly provisional and discretionary, a temporary measure with the U.S. left free to 
"do as much as we wanted only for as long as we wanted," and unhindered from withdrawing its troops at any time..$^{29}$

Dulles was delivering his instructions as his staff was putting the finishing touches on a new U.S. draft of the bilateral security agreement. Dulles' personal mood of angry hauteur spilled over to influence its crafting, for the wording, though correct and austere, hid a harsh and vindictive spirit, a desire to punish the Japanese side for their pusillanimity. Completed on February 5, 1951, the critical language adopted here would remain at the heart of the treaty even to its final adoption and signing seven months away:

...Japan desires, as a provisional arrangement for her defense, that the United States...should maintain armed forces of its own in and about Japan so as to deter armed attack upon Japan.

The United States, in the interest of peace and security, is presently willing to maintain certain of its armed forces in and about Japan, in the expectation, however, that Japan will itself increasingly assume responsibility for the defense of its homeland against direct and indirect aggression

....Japan grants, and the United States accepts the right...to station United States land, air and sea forces in and about Japan. ${ }^{30}$

Embellishing upon the above privileges, and in accord with key portions of the State-Defense agreement of September 14, 1950, the United States reserved veto power over any proposed military activity on Japanese soil by a third power. Over Japanese objections, Dulles insisted the U.S. possess the authority, at the request of the Japanese Government, to "put down large-scale internal riots and disturbances"; the Japanese side meekly countering only that the phrase "caused through the instigation of outside Powers" be tacked on to the formulation. ${ }^{31}$ To protect its strategic investment the U.S. would not permit revolution. 
It is something of a wonder that the Japanese ever gave their consent to so lopsided an agreement, one so different and promising so much less than the one Prime Minister Yoshida had hoped for. There was no ironclad guarantee for Japan's security, and no basis for mutual cooperation between the countries for Japan's defense. The terms had been virtually dictated by the United States, under an arrangement that gave the U.S. complete latitude to determine the extent of its responsibilities within its wider interests in safeguarding the security of East Asia and the western Pacific. The deal was perhaps politically acceptable to Japanese opinion only because of one of its principle weaknesses, framed as it was as being something of a stop-gap measure, something temporary and unavoidable.

Yet it is certainly possible to think that Yoshida may have gotten the better of the bargain. As far back as his first term in office, the Prime Minister had coveted some kind of security alliance with the principal Power of the Pacific, and now a major conflict upon Japan's historic frontier convinced him of its utter necessity. Yoshida wanted the United States to defend Japan, and the United States had agreed to do so -- on its own terms, of course, but the same might be said of Japan as well. Though he had wished for something firmer, Yoshida was quite willing to settle for the sort of de facto guarantee that the presence of U.S. soldiers represented. He had achieved a potent measure of security at home, and in areas of vital interest, but at very little economic or social cost. And he had attained it with his two foremost goals intact: a generous peace treaty would soon be realized; and Japan remained uncommitted to either the creation of a sizable military 
establishment or encumbered by the kinds of regional military responsibilities the United States had urged upon it.

Which is not to say that something was not sacrificed all the same. Dulles, in his inimitable manner, had pushed the Japanese to assume the reins of sovereignty and join the U.S. as a full partner in its perilous global crusade. The Japanese had weighed the cost, but had deemed it too great. Belatedly perhaps, Yoshida recognized that his priorities had forced his country into a dependent embrace with a fickle partner, in need of endless placating and full of continual demands that could not be easily disregarded. At least not until Japan was ready to take up the burden of its own defense. "To rearm at this time would cause a split among the Japanese people. Because of such considerations I am opposed to rearmament at this time," Yoshida said publicly in February 1951, at the end of the Dulles visit, yet Japan had "a right and an obligation to defend its own security. ${ }^{132}$ Despite the contradictions, such an obligation could not be fulfilled without armies and weapons.

\section{REARMAMENT}

General MacArthur had no such apprehensions. His cherished dream of an unarmed Japan had evaporated under the pressures of military necessity. Before Dulles had even arrived in Tokyo to push for rapid rearmament, General MacArthur and the Pentagon were busy designing the nucleus of the new Japanese army. There is some doubt as to whether MacArthur initially envisaged the NPRJ 
[National Police Reserve - Japan], which he himself had ordered into being, as a proto self-defense force with military capabilities. Under the dire circumstances of being routed on the Korean peninsula, he nevertheless quickly grasped its possibilities.

On January 3, 1951, the General submitted a detailed list to the Pentagon of equipment to be rushed to the NPRJ, whose units he wanted procured on an equal priority basis with the South Korean Army. Up to this point the U.S. had provided the four "divisions" of the Reserve with weaponry no heavier than carbines. MacArthur now wanted medium tanks and $155 \mathrm{~mm}$. howitzers, bazookas and heavy machine guns. At first, even the Pentagon had doubts about the wisdom of the first pair of items, but MacArthur was easily able to persuade the JCS otherwise, in view of the threat to Japan which was "expected to become particularly acute by early May." Faced with a communist invasion, if the Japanese forces were not equipped with heavy armaments, their fate would repeat that of the armies of the ROK. On February 9, the JCS urged Secretary Marshall to immediately ship MacArthur the items he had requested. ${ }^{33}$

There was recognition that this was a sensitive business. "We feel that you may wish to discuss this matter with the Secretary of State and the President," Chairman Bradley advised Marshall. Because the project could not risk public disclosure, the JCS recommended establishing a secret fund to pay for it, rather than submit it to Congress as part of the Pentagon's annual budget. And having 
recovered from their initial qualms, the JCS considered MacArthur's request for equipment for four divisions inadequate; the JCS wanted enough for ten. ${ }^{34}$

Marshall signed off on the idea and brought it to Acheson's attention, but the plan soon generated considerable interest beyond the confines of the State Department. The CIA came to the swift conclusion that the Soviet Union:

...would not resort to direct military action merely to prevent the conversion of the Japanese National Police Reserve in fully equipped divisions...[but] should the USSR decide to invade Japan, even a partial rearmament of Japan would of course provide a convenient pretext....However, the existence of such a Japanese force, supplemented by available US Forces, would make a Soviet invasion of Japan a major military operation....There are no positive indications that the USSR intends to attack Japan by mid-April 1951, but has the capability of doing so and could launch such an attack without any appreciable warning. ${ }^{35}$

Meanwhile Assistant Secretary of Far Eastern Affairs Dean Rusk told Acheson what he already knew -- the Pentagon plan was a clear violation of FEC policy. Furthermore, Rusk reminded him that Dulles had only weeks before publicly vowed that Japanese rearmament would be a decision made by an independent Japan: thus, "...there is likely to be a considerable degree of revulsion by the Japanese to their being rearmed at the unilateral decision of the United States...without their being given any opportunity whatever to participate in the decision. ${ }^{136}$

Acting Secretary of State James Webb conveyed to Marshall the Department's many concerns: principally, that such a plan if it became known would jeopardize the ongoing peace treaty negotiations. They were, nonetheless, not considered sufficient reason for not going forward. State concurred that equipment for the four divisions of the NPRJ be shipped immediately so as to be 
available in an "emergency," and planning and budgeting for the remaining six divisions should proceed as outlined. With however, one major stipulation. "It is the understanding of the Department of State," Webb wrote, "that none of the equipment will be placed in the hands of the Japanese without the specific prior approval of the State Department. ${ }^{137}$ Webb asked for confirmation, which the Defense Secretary gave to Acheson on April 20, 1951. Truman approved the plan on May 1, with the expectation that by July 1,1952 , ten fully equipped divisions of the NPRJ would come into being. ${ }^{38}$

Such a supposition was fully supported by a CIA study published at about the same time. ${ }^{39}$ The conclusions of the report displayed a remarkable breadth of vision, describing how best the United States might utilize and maximize Japan's human and industrial potential for its own military ends. It was the position of the study that the Japanese "would have preferred to assume a neutral status in world affairs in order to bargain freely with all powers and thus obtain maximum national advantage," but the Korean war and historic animosities towards Russian had demonstrated how illusory was such a goal. The hoped for result was a Japan, once independence was returned, which would remain pliant towards U.S. demands. Strategically, such prospects invited grandiose plans. "A Japanese army of up to 500,000 men theoretically could be created within six months or a year....Its nucleus would be the 75,000 men now in the National Police Reserve, who are receiving [perhaps clandestine?] US training and equipment." Industrially, the prospects were no less inviting: Japan might soon manufacture everything from rocket guns to light 
tanks. A military establishment of such size and potential might exceed the requirements of self-defense. The difficulties of finding a political leadership in Japan will to go along in such an undertaking was not specifically addressed. Nor was the question of just how long such an arsenal Japan might be expected to conform its desires to the outlines of American policy, except to note that they would be determined by the Japanese according to vaguely sinister "opportunistic considerations. ${ }^{40}$

\section{FINISHING TOUCHES}

With work on the security treaty nearly complete, Dulles left Japan on February 11, proceeding to the Philippines, and then to Australia and New Zealand before returning to Washington on February 22. By then the hope that he had carried with him initially of a Pacific Pact was dead. The Japanese had been decidedly non-committal; the British opposed it as inimical to their interests on the Asian mainland, from Hong Kong to India; the mood in the Philippines (whose security was already vouchsafed in the form of U.S. bases), Dulles rued, was like that of France in 1919; and the Australians and New Zealanders, from considerations of their public opinion among other reasons, felt it would be impossible for them to be party to any arrangement which would obligate them to come to Japan's defense. Which was not to say that the nations of the Pacific did not desire some accommodation with the U.S. on security matters, just that they be 
concluded as separate agreements. The lack of a community of shared interests excluded any chance of a truly regional approach to Pacific defense. ${ }^{41}$

Their real fear was not of the Soviets, but of a resurgent Japan. Australia and New Zealand began by insisting to Dulles that a peace treaty must contain stiff controls on Japanese rearmament and other punitive provisions, arguments Dulles crushingly rejected. The United States would not assume the international duty of enforcing stringent terms upon the Japanese in a repeat of the Versailles treaty, and as no other power could, these were dead issues. Besides, Dulles averred, in a moment of glimmering lucidity:

The thing I worry about...is that Japan will not create adequate armed forces. There is no worry in our minds about an unduly large force or naval or air forces. The U.S. is not willing to station forces in Japan for very long unless the Japanese do something on their own account. It would be unwise to take action...which could be used as an excuse by the Japanese for not doing all they can for their own defense.... Their tendency is all too likely to be to stay neutral, to seek the continued presence of U.S. forces, and to concentrate on raising their standard of living. It must be a strange thought to you to consider that the problem for the next five to ten years will be to get Japan to create land forces but that is the case. ${ }^{42}$

The Pacific Dominions were not in an especially strong position to resist either the will of the United States, or that of Ambassador Dulles. When he returned to Washington, the details of what would become the ANZUS treaty had been all but approved. Truman publicly confirmed the arrangement on April 18, 1951. ${ }^{43}$

In mid-March, Dulles wrote MacArthur a warm, personal note, confirming his continuing efforts to put the final touches on the security treaty with Japan despite "occasional signs of relapse in the Pentagon," but otherwise strong support 
from the administration, Congressional Committees, the press and the public. If Dulles had had earlier misgivings about the competence or the character of the man, they had been overcome by admiration, and the Ambassador expressed his grateful thanks. The General's role in the continued success of his endeavors was "central, dominating and indispensable." ${ }^{14}$ In three weeks MacArthur would be gone.

Late in the evening of April 10, Acheson summoned Dulles to his home to inform him that Truman would relieve MacArthur within a few hours. The Japanese, Dulles was afraid, might construe the General's abrupt dismissal as a kind of palace coup orchestrated by elements of the Pentagon opposed to the conclusion of a peace treaty, and that the removal signaled a reversal of U.S. policy in that regard. Dulles' flair for the self-dramatic led him to conclude that he was "the only person who could perhaps salvage the situation in Japan." Truman, Acheson and Republican leaders urged him to proceed promptly to Tokyo to inform the Japanese leadership and public that "the President was more than ever determined to proceed strongly and vigorously" towards peace, and that U.S. policy towards Japan and East Asia remained unchanged. ${ }^{45}$ Dulles' third trip to Tokyo was immediately announced to the press and he departed two days later. ${ }^{46}$

The imagined crisis was in a sense anticlimactic. Though Prime Minister Yoshida had been "visibly shaken" at the news of MacArthur's removal, ${ }^{47}$ after reassurances on both sides had been given, the General's passing produced barely a ripple of discontemt. Most of Dulles' time in Tokyo was spent on matters unrelated 
to the security treaty. But the signs of Pentagon "relapse," as Dulles had termed it, did occasionally crop up in his discussions with the Japanese, at the time of his trip and over the ensuing months. Having been unable to prevent the treaty negotiations from going forward, the JCS disingenuously seized upon a number of fresh tacks in search of delays, much to the irritation of Dulles and State Department.

The most serious occurred in June 1951. It was the fresh position of the Pentagon, contrary to previous understandings, that the United States retain a perpetual veto over the peace treaty coming into effect amongst the signatories until the conclusion of the war in Korea. Acheson promptly took the matter straight to Truman, who then overruled the Joint Chiefs. Yet as a direct result of this encounter the "addendum" that Dulles had negotiated in January which provided for the continued use of Japanese facilities by UN forces fighting in Korea was subsequently broadened to include the entire Far East, should hostilities spread to other areas. $^{48}$

It was nonetheless a successful tactic that would soon be repeated again. On July 10, 1951, Dulles submitted the latest draft of the U.S.-Japan Security Treaty to Secretary of Defense Marshall, indicating that the text had been shown to the Japanese, who found it acceptable. The Senate Foreign Relations Committee and House Foreign Affairs Committee, bodies which Dulles had been in frequent and judicious contact, had "indicated their general approval." It was now the Pentagon's turn for comment. ${ }^{49}$ 
The JCS and the Secretaries of the Armed Services were unanimous on one point:

From the strategic viewpoint, it would be entirely untenable for the United States to commit a significant proportion of its ready forces in such a manner that they would not be available for immediate United States use from the bases in which deployed. Accordingly, it should be made unmistakably clear that the responsibilities of the United States forces are not limited to the territory of Japan..$^{50}$

Their objections arose over the wording of Article I of the current Dulles draft. In it, the "disposition" of U.S. forces "would be designed to contribute to the security of Japan against armed attack from without...." ${ }^{51}$ Provision had not been explicitly delineated for what the Joint Chiefs really wanted: the unilateral right of U.S. forces to use Japan as a base of operations for waging war on the Asian mainland. As the service secretaries informed Marshall, agreement for "the utilization of such forces...in areas other than Japan or its immediate vicinity," must be secured. ${ }^{52}$

Tense negotiations ensued. On August 2, Dulles informed the Secretary of State:

We have now agreed with the Department of Defense on the draft Bilateral Security Treaty, and our draft has also been accepted by the Japanese Government. The Joint Chiefs of Staff receded somewhat from their extreme position and I feel reasonably satisfied with the result.

Yet both Dulles and the Japanese had had to retreat before the Pentagon's unassailable military logic. The language of compromise which Dulles had worked out sounded innocuous. He had embellished his earlier text to read that U.S. forces "may be utilized to contribute to the maintenance of international peace and security in the Far East, and to the security of Japan....," but he was enough of a 
diplomat to realize that his formulation would fool no one. Precautions would have to be taken, he continued to Acheson:

It is, however, agreed between Defense and ourselves that we should defer as long as possible publication of the text as it would undoubtedly be used by unfriendly elements to attack the peace settlement as in essence giving the United States the right to use Japan as a military base to carry an offensive threat to Russia and China.

The wording of the security treaty had, nonetheless, been finalized, the work complete except for the signing.

\section{CEREMONY}

On the morning of September 8, 1951, delegates from forty-nine countries had signed the Treaty of Peace at the San Francisco Opera House which brought World War II to a close, nearly six years after MacArthur had accepted the instrument of surrender aboard the USS Missouri as it sat moored in Tokyo Bay. It was a scene was much in contrast to the private, muted, nearly furtive atmosphere at 5 p. m. that same afternoon as the two delegations, one from Japan, headed by Prime Minister Yoshida, and the other from the United States, gathered at the Presidio, U.S. Army Headquarters for the Western United States, to sign the United States-Japan Bilateral Security Treaty. As agreed, the text of the treaty had been made public only an hour before the scheduled signing.

If the morning had been given over to a spirit of hopeful idealism, as a clouded past was buried amidst the desire for a new beginning, the later ceremony was an austere reminder, not only of the present's grim realities, but of the 
impossibilities of entirely escaping the confines of history. Secretary Acheson spoke briefly, emphasizing that the treaty represented a "voluntary arrangement between free peoples," which had been formulated "in a spirit of trust and confidence," almost as if trying to convince at least himself that his words were true. As if giving them the lie, the Secretary, echoing the document before him, told those assembled that it was the expectation of the United States that Japan would soon shoulder the burden of its own defense. Yoshida too, when it was his turn, spoke of the temporary nature of the agreement he was about to sign, of his hope that Japan would do more. After the signing -- Yoshida for Japan and Acheson, Dulles, Senators Wiley and Bridges for the United States -- there took place the exchange of notes wherein Japan formalized its pledge to continue its cooperation with UN military actions in the Far East after the peace treaty had come into effect, an understanding still in force to this day. ${ }^{53}$

For all the avowals that what they had done was of a transient nature, it might seem remarkable to those assembled there how little change four decades has wrought. Would they have paused if they had known that the awkward pattern that they cut would harden over the years to form the bedrock of future relations between their respective countries? Indeed, more than they knew, the security treaty was a new beginning. Both parties had got what they wanted most, a Japan nominally to be counted among the members of that old fashioned club, the free world. Yet the Japanese had resisted paying their dues by rejecting the very idea of reciprocity, pleading, as has become all to familiar, the barrier of special 
circumstances. As a result, Japan began its renewed independence firmly tethered to the U.S. The United States had secured, against its better judgement, a dependent, not a partner. But given the background of domination and distrust perhaps no other outcome should have been expected. There thus took place that September afternoon a marriage of convenience; but also a marriage of necessity, built up upon a fragile foundation of unequal power and status which then gave rise to widely different expectations. To no surprise the obstacles to harmony had been only partly overcome. The shock derives from their endurance. 


\section{NOTES}

\section{Weinstein, pp. 56-57.}

2. Article 51 reads: "Nothing in the present Charter shall impair the inherent right of individual or collective self-defense if an armed attack against occurs against a Member of the United Nations, until the Security Council had taken measures necessary to maintain international peace and security." The draft treaty is given in Ibid., pp. 57-58.

3. Curtis, p. 49.

4. Igarashi, p. 329; Masumi, pp. 206-207.

5. Auer, p. 76. It is known that Nomura discussed his plan with U.S. Admirals Burke and Joy as well as with the Yoshida Government, and that its contents were revealed to Dulles at a Tokyo party in February 1951, and led to further discussions. In March 1951, Watanabe Tetuzo, an anti-communist businessman and academic, as the head of a group of thirty business and military men, called for a 300,000 man army, 300,000 ton navy, and 3,000 aircraft. The study had been partially funded by the Yoshida Government, though the Prime Minister disagreed with its extreme conclusions. A very similar proposal was advanced by former vice admiral Takagi Sokichi in a popular Japanese magazine at almost the same time. Later in the year Hattori Takushiro, a onetime member of Tojo's General Staff, and a close associate of General Willoughby (head of SCAP's intelligence division - G-2) advocated the creation of twenty infantry divisions. See Ibid., pp. $74-76$ \& p. 276 ; Dower, p. $387 \&$ pp. 568-569, respectively.

6. FRUS, 1951, vol. 6 (January 4, 1951), pp. 780-782; McCullough, pp. 832-834.

7. FRUS, 1950, vol. 6 (December 13, 1950), pp. 1363-1364; FRUS, 1951, vol. 6 (January 9, 1951), pp. 787-788.

8. Ibid. (January $9 \& 10,1951$ ), pp. 787-789.

9. Ibid., pp. 790-791.

10. Ibid. (January 18, 1951), pp. 804-805.

11. John Foster Dulles, "Peace May Be Won," Department of State Bulletin, vol. 24, no. 606 (February 12, 1951), p. 253. 
12. Weinstein, p. 59.

13. FRUS, p. 832.

14. Ibid., p. 829.

15. Ibid., p. $810 \&$ p. 867 . Yoshida's disquiet may at the time have come not only from his discussions with ex-officers like Nomura on rearmament, but from a shortage of officers with which to staff the National Police Reserve, leading to a feeling that it might be necessary to "de-purge" a number of wartime figures - a program that the Pentagon came to push for with some vigor. Ibid., p. 837.

16. Allison, p. 157.

17. One of the main theses of Johnson, pp. 305-324; and Karel van Wolferen, "The Japan Problem Revisited," Foreign Affairs, vol. 69, no. 4 (Fall 1990), pp. 42-55.

18. In July of 1954 , Yoshida finally created, not a Defense Ministry, but a Defense Agency, a designation of much reduced status and autonomy. Ever after, Ministry of Finance has effectively stunted the Agency's growth by tight budget control. Dower, pp. 436-470.

19. FRUS, p. 829.

20. Ibid., pp. 833-834.

21. Igarashi, p. 350.

22. Considered vital to winning Defense Department approval of any arrangement, this agreement, an addendum to the security treaty, was completed on February 9 , 1951 and formalized by an exchange of notes on the same day the security treaty was signed. See Yoshida, p. 268.

23. FRUS, pp. 848-849.

24. Yoshida, p. 267. The plan, rather vague on specifics, was submitted to the American side on February 3, and called for a limited, all-purpose 50,000 man force (not quite two divisions) committed to self-defense and democratic principles. It was not enacted, at least as outlined, in any case. FRUS, p. 849; Igarashi, p. 331.

25. FRUS, p. 844.

26. Weinstein, p. 60.

27. "Japanese Peace Treaty Negotiations (March 9, 1951)," Executive Sessions of the 
Senate Foreign Relations Committee (Historical Series), vol. 3, pt. 1. 82nd Congress, 1st Session (Washington, D.C.: U.S. Govt. Printing Office, 1976), p. 263.

28. FRUS, p. 857.

29. Ibid., p. 858; Executive Sessions, op. cit.

30. FRUS, p. 856 [italics mine].

31. Ibid., pp. $856-857 \&$ p. 860 .

32. Ibid., p. 893; Dower, p. 437.

33. FRUS, p. $808 \&$ pp. $884-885$ (fn. 4).

34. Ibid., pp. 884-885.

35. From "Probable Effects on Soviet Intentions and Capabilities of Arming the Japanese National Police Reserve as Four Fully Equipped Divisions," (February 21, 1951), portions of which are quoted in Ibid., pp. 890-891 (fn. 5).

36. Ibid. (February 22, 1951), p. 893.

37. Ibid. (March 1, 1951), pp. 898-900.

38. Ibid., pp. 1001-1002.

39. NIE-19, "Feasibility of Japanese Rearmament in Association with the United States," Ibid. (April 20, 1951), pp. 993-1001.

11. FRUS, p. 1364.

12. Ibid. 


\section{CHAPTER IX}

\section{CONCLUSION}

The signing of the peace and security treaties in many ways meant merely exchanging one set of problems for another. Now that Japan had been induced to join the free world, the difficulty would become keeping it there. For as Dulles told President Truman:

It would be very difficult to alter the relationship from that of a victor who ruled the people they had conquered to a relationship of equals. I thought it particularly important that some concrete steps be taken to indicate the changeover of Japan from an occupied country to a sovereign equal. I mentioned to the President that when talking with General MacArthur...I had laughingly said to him that he had won many victories, but the greatest victory of all would be if he succeeded in getting the colonels out of the Japanese villas. ${ }^{1}$

Yet that sought for equality would need to take place within a political arrangement which was anything but equal. "On the one hand we must keep in mind the basic reality governing our relations with the Japanese," wrote the new SCAP, General Matthew Ridgway, shortly after the treaties had been signed:

This will be the reality of sovereign power. In theory Japan will be sovereign. In practice the survival of that sovereignty will reside in the power of the United States Armed Forces stationed on her soil....Until such time as Japan shall have created the minimum essential means reasonably to safeguard her political and territorial integrity...her independent national existence will rest not in her hands, but in those of the United States. ${ }^{2}$ 
The JCS, in a crude and ugly fashion, put the matter bluntly: "...the position of Japan, as a conquered nation and as an oriental nation is not analogous to that of the [NATO] nations."

For all the earnest professions of good will, the tenor of the new relationship bore a distinct resemblance to the old. At the end of December 1951, Dulles informed Yoshida that it would be "totally unrealistic" as well as "utterly destructive" for Japan to pursue a foreign policy at variance with that of the United States. If indeed Japan intended to follow an independent course, Dulles rather sinisterly continued, "...it would make it utterly impracticable to realize the benevolent program we have in mind for Japan."4 Japan might have its sovereignty, but it had better fall in line.

The better part of that accommodation was expected to come from Japanese acquiescence, if not hearty cooperation, with U.S. military objectives. Only days before the security treaty had been signed tanks and heavy artillery destined for the NPRJ had surreptitiously cleared U.S. ports. ${ }^{5}$ By the end of November, Japanese forces were being secretly trained in its use at U.S. bases. ${ }^{6}$ In December 1951, the Pentagon quietly earmarked $\$ 300$ million for the "rapid establishment of a small Japanese army" from a discretionary fund. ${ }^{7}$ The Japanese, it was believed, would be forthcoming with the necessary constitutional amendments and the creation of a Ministry of Defense.

There was a certain inevitability to the subordination of other objectives and considerations once the issue of security assumed its preponderant place at the apex 
of U.S. foreign policy. A debate so framed axiomatically became the province of those within the Pentagon and the Department of Defense who bore the final responsibility for its preservation. The increased reliance upon covert activities was only the consequence, the means by which a higher value was to be realized, at the expense of cumbersome and inconvenient legalities. Other patterns and preoccupations which would become all too drearily familiar, had begun to emerge. Even the lavish allocation of weaponry to Japanese forces was not free of ulterior motives. U.S. arms would serve as an instrument of political control, the best way to insure the loyalty and good behavior of the Japanese military. A strategic vision was necessary to accompany these plans, and in due course one would be provided, a formulation still in its infancy: "...the loss of Southeast Asia to the Western World would almost inevitably force Japan into an eventual accommodation with the Communist-controlled areas in Asia. Viewed in this context United States objectives with respect to Southeast Asia and United States objectives with respect to Japan appear to be inseparably related."

Yet the position of the United States, for all its seemingly overwhelming power, was a delicate one. The urge to exploit its domineering advantage had to be constantly tempered by the need to nurture stability as well. Prime Minister Yoshida, at times, rued the ideological division wrought upon his country by the occupation, but he was not unaware that it had its political uses. Yoshida, who through the years of occupation had become quite accustomed at dodging SCAP demands, expertly parried U.S. importunities for greater military contributions. He 
warned frequently that he could not afford to give the impression that Japanese forces would become a "tool," or sacrificed as "cannon-fodder" for U.S. objectives. To do so would sound "the death knell of the Liberal Party." ${ }^{\prime 9}$ What ever the U.S. might think of the Yoshida Government, it could not press too hard; for as William Sebald informed Dean Rusk, "it is necessary to recognize that in the present political circumstances there appears to be no desirable alternative." ${ }^{10}$

Unintentionally or no, in its quest for stability the United States would serve as the nursemaid to the one-party state. Congenially so, from the interests of Japanese conservatives like Yoshida, whose commitment to values of political liberalism were tepid at best, who cherished order above all else, and who had always regarded liberal ideals as exotic, foreign impositions. But that the United States would sacrifice its commitment to democracy in the interest of stability spelled the strangling of the last strains of idealism in American foreign policy. It had been the fervent, touching belief in 1945 that a future democratic Japan was the last and best guarantee of U.S. security. By 1952, U.S. policy makers were prepared to accept a reasonably pro-American regime committed to the stationing of U.S. troops as the best they were likely to get.

On the morning of December 4, 1952, John Foster Dulles met with Ambassador Shirasu Jiru at the Shoreham Hotel in Washington D.C. Dulles had long since left the service of the Truman Administration. Indeed, he had quite recently been named as Secretary of State by the newly elected President Eisenhower, who had remarked so famously during the campaign that it was his 
intent, when waging distant wars, that Asians fight Asians. It was perhaps the rather visceral image conjured up by the sloganeering of the campaign trail that had prompted the Prime Minister to make the personal request of his old antagonist that he speak with Shirasu.

The conversation between the two men was a curious one, under the circumstances, very unlike a confidential exchange between diplomats, more like a plea from a supplicant servant to stern master:

Mr. Shirasu said that the Prime Minister was particularly concerned over the pressures to which the Japanese Government was being subjected in relation to rearmament. He said that the Japanese people had been educated to the belief that it was wrong to have a military establishment; this was in the Japanese Constitution, and it would not be possible to develop any large armament without first re-educating the Japanese people. ${ }^{11}$

Dulles was at first somewhat taken aback. He maintained that he could not speak in any official way for the incoming Administration and that the matter had never come up in any discussion with General Eisenhower. He himself, he said, had never publicly urged rearmament on the Japanese people, that it was not a proper role for outsiders. Yet:

I stated that I believed that the Japanese people must realize that they would not be a fully sovereign nation so long as they were wholly dependent upon another nation for their protection in a world of danger; that they must realize that as a matter of their self-respect they would have to bear some responsibility and fair share of the common burden of defense of the free world. ${ }^{12}$

The brief exchange encompassed large themes. It might even stand in as a condensation, a poignant distillation of a brief, yet traumatic era. Two countries so different as Japan and the United States were incommensurably divided, first by 
war, and then by their varying understanding of peace. The relationship that had been forged with so much travail has continued through the years to be punctuated by tensions and unallayed suspicions. The unavoidable betrayal of idealism by a harsh world is a universal human motif; and its meanings are tragic, for individuals as for nations. But here such a meaning might be tempered by a consideration that it did not seem to matter all that much. After a fashion, both parties got what they wanted.

An earlier generation of scholarship, which gazed at the world through the lens of the Vietnam war and their own disenchantment with the wayward application of American power, came to the conclusion that the United States had, in the years following the Second World War, refashioned itself as the last of the imperial powers. In the case of Japan, imperial pretensions had sought, and coerced, a complacent American client state on the rim of Asia. But perhaps imperialism isn't quite right.

"The cold war is over and Japan has won," has become both a slogan and a lament of recent years. In an ironic way the sentiment reconfirms the strategic assessment made by U.S. policy makers at the cold war's malevolent dawn: a nation of potential so vast that its inclination could decisively tip the scales of the world balance of power. Once framed in this way, the question that then preoccupied the Truman administration, one contemplated with ballooning urgency as Korea raged, was "what price Japan?" Prime Minister Yoshida had a ready answer and a political horse-trade of a very high order was the result. For the de facto guarantee of 
Japan's security given by the stationing of U.S. forces on Japanese soil, Japan would, to borrow the Chinese phrase "lean to one side."

There would nonetheless be some rather severe limitations to how pliable the Japanese could be expected to be. Thus a common thread runs through all of the Prime Minister's steadfast arguments against Japanese rearmament. Yoshida had only given the overriding need to preserve domestic stability -- the fundamental concern of Japanese politics since the Tokugawa -- a contemporary twist.

Rearmament threatened to unleash social forces of mass opinion, of the political left, and the militarist right, which would jeopardize the still fragile consensus of conservative civilian rule and its emerging economic priorities.

U.S. officials griped about the lack of reciprocal obligations and understandings, but were prepared to give in. And not only out of an abiding interest in Japan's political stability; but out of concern that a rearmed Japan might not always grant the military free hand which U.S. negotiators had extracted as the price the Japanese would pay, not just for their security, but for the restoration of their sovereignty. Japan's economic diversions were finally preferable to other possible pursuits.

Yoshida and his negotiators were shrewd and skillful men, and it is certainly possible to conclude that the Prime Minister realized his ambition of winning the peace after losing the war. Yet what he had won in the name of political cohesion and a nominal restoration of sovereignty left a legacy of dependency that further 
clouded those questions of national identity and purpose that in the years since defeat have remained open-ended and unanswered.

Through the years Japanese foreign policy came to exhibit a kind of dual personality, both vestiges of unresolved dilemmas of the Yoshida era. One, for public consumption, extolled a uniquely Japanese mission, as victims of atomic holocaust, to uphold the example of peace without a resort to arms. The other, the province of Japan's ruling class of politicians, bureaucrats and businessmen, was a neo-mercantilist policy of economic nationalism and expansion. Neither could have existed, let alone flourished, without a security policy derived from a near exclusive reliance upon the armed forces of the United States. The result, at the end of the cold war, was a Japan economically formidable, but weak in those attributes of sovereignty by which nations must find their way in an unpredictable and hostile world. A military past, for which it has trouble accounting, and a vast, though unrealized military potential, continues to ensure a goodly measure of distrust of Japanese motivations; while at the same time, Japan currently lacks many of the institutional attributes needed to chart its independent course.

If this was not exactly what U.S. officials originally envisaged, neither is the result particularly surprising. The price the Japanese exacted for their cooperation with Washington's global strategies was a high one. That Washington looked askance when its desires for rearmament and collective security were rebuffed only confirms the importance which Washington attached to the preservation of the relationship, and cherished the advantages which were reaped from the stationing of 
American troops from Japanese bases. It only betrays the degree to which official thinking came to be dominated largely by military considerations, oddly divorced from political contexts.

At the very least, it is a story rich in unintended ironies. They stem, largely if not wholly, from two great, and for the most part unforeseen consequences of the Pacific War. Firstly, that the United States, as the primary antagonist to the creation of the Japanese empire, should prove its principal inheritor upon its demise. And secondly, from the deep division of Japanese political life that occurred as Washington altered or abandoned its initial postwar policies of reform in response to inescapable strategic quandaries which its unexpected inheritance had bequeathed. The meaning of security at the dawn of the cold war thus came, at its demise, to portray a stark study in contrasts: as one nation choose to pursue economics as a substitute for politics, while the other refashioned its military might to roughly the same, though perhaps unintentioned, end. 


\section{NOTES}

\section{Weinstein, pp. 56-57.}

2. Article 51 reads: "Nothing in the present Charter shall impair the inherent right of individual or collective self-defense if an armed attack against occurs against a Member of the United Nations, until the Security Council had taken measures necessary to maintain international peace and security." The draft treaty is given in Ibid., pp. 57-58.

3. Curtis, p. 49.

4. Igarashi, p. 329; Masumi, pp. 206-207.

5. Auer, p. 76. It is known that Nomura discussed his plan with U.S. Admirals Burke and Joy as well as with the Yoshida Government, and that its contents were revealed to Dulles at a Tokyo party in February 1951, and led to further discussions. In March 1951, Watanabe Tetuzo, an anti-communist businessman and academic, as the head of a group of thirty business and military men, called for a 300,000 man army, 300,000 ton navy, and 3,000 aircraft. The study had been partially funded by the Yoshida Government, though the Prime Minister disagreed with its extreme conclusions. A very similar proposal was advanced by former vice admiral Takagi Sokichi in a popular Japanese magazine at almost the same time. Later in the year Hattori Takushiro, a onetime member of Tojo's General Staff, and a close associate of General Willoughby (head of SCAP's intelligence division - G-2) advocated the creation of twenty infantry divisions. See Ibid., pp. $74-76$ \& p. 276 ; Dower, p. $387 \&$ pp. 568-569, respectively.

6. FRUS, 1951, vol. 6 (January 4, 1951), pp. 780-782; McCullough, pp. 832-834.

7. FRUS, 1950, vol. 6 (December 13, 1950), pp. 1363-1364; FRUS, 1951, vol. 6 (January 9, 1951), pp. 787-788.

8. Ibid. (January $9 \& 10,1951)$, pp. 787-789.

9. Ibid., pp. 790-791.

10. Ibid. (January 18, 1951), pp. 804-805.

11. John Foster Dulles, "Peace May Be Won," Department of State Bulletin, vol. 24, no. 606 (February 12, 1951), p. 253. 
12. Weinstein, p. 59.

13. FRUS, p. 832.

14. Ibid., p. 829.

15. Ibid., p. $810 \&$ p. 867 . Yoshida's disquiet may at the time have come not only from his discussions with ex-officers like Nomura on rearmament, but from a shortage of officers with which to staff the National Police Reserve, leading to a feeling that it might be necessary to "de-purge" a number of wartime figures - a program that the Pentagon came to push for with some vigor. Ibid., p. 837.

16. Allison, p. 157.

17. One of the main theses of Johnson, pp. 305-324; and Karel van Wolferen, "The Japan Problem Revisited," Foreign Affairs, vol. 69, no. 4 (Fall 1990), pp. 42-55.

18. In July of 1954, Yoshida finally created, not a Defense Ministry, but a Defense Agency, a designation of much reduced status and autonomy. Ever after, Ministry of Finance has effectively stunted the Agency's growth by tight budget control. Dower, pp. 436-470.

19. FRUS, p. 829.

20. Ibid., pp. 833-834.

21. Igarashi, p. 350.

22. Considered vital to winning Defense Department approval of any arrangement, this agreement, an addendum to the security treaty, was completed on February 9, 1951 and formalized by an exchange of notes on the same day the security treaty was signed. See Yoshida, p. 268.

23. FRUS, pp. 848-849. 


\section{SELECTED BIBLIOGRAPHY}

Acheson, Dean. Present At the Creation: My Years at the State Department. New York: W.W. Norton and Company, 1969.

Allison, John M. Ambassador from the Prairie: or Allison Wonderland. Boston: Houghton Mifflin, 1973.

Auer, James E. The Postwar Rearmament of Japanese Maritime Forces, 1945-1971. New York: Praeger Publishers, 1973.

Beloff, Max. Soviet Policy in the Far East, 1944-1951. London: Oxford University Press, 1953.

Blaker, Michael K. "Probe, Push, and Panic: The Japanese Tactical Style of International Negotiations," The Foreign Policy of Modern Japan. Edited by Robert A. Scalapino. Berkeley: University of California Press, 1977, pp. 55101.

Buruma, Ian. "The Pax Axis," New York Review of Books 38.8:25-39 (April 25, 1991).

Cole, Allan B., George O. Totten and Cecil H. Uyehara. Socialist Parties in Postwar Japan. New Haven, Connecticut: Yale University Press, 1966.

Colton, Kenneth E. "Pre-war Political Influences in Post-war Conservative Parties," The American Political Science Review 42.5:940-957 (October 1948).

Combs, Jerald A. (ed.). Nationalist, Realist, and Radical: Three Views of American Diplomacy. New York: Harper \& Row, 1972.

Curtis, Gerald L. "The Dulles-Yoshida Negotiations on the San Francisco Peace Treaty," Columbia Essays in International Affairs -- The Dean's Papers, 1966. Vol. II. Edited by Andrew W. Cordier. New York: Columbia University Press, 1967, pp. 37-61.

Destler, I. M., Hideo Sato, Priscilla Clapp, and Haruhiro Fukui. Managing an Alliance: The Politics of U.S.-Japanese Relations. Washington, D.C.: The Brookings Institution, 1976. 
Dingman, Roger. "The Impact of the Korean War on the Occupation of Japan," The Occupation of Japan: The Impact of the Korean War (Proceeding of the Seventh Symposium Sponsored By the General Douglas MacArthur Foundation - October 1986). Edited by William F. Nimmo. Norfolk, Virginia: The General Douglas MacArthur Foundation, 1990, pp. 179-186.

Dower, J. W. Empire and Aftermath: Yoshida Shigeru and the Japanese Experience, 1978-1954. 2nd. ed. Cambridge, Massachusetts: Council on East Asian Studies, Harvard University, 1988.

"Occupied Japan and the American Lake, 1945-1950," America's Asia: Dissenting Essays on Asian-American Relations. Edited by Edward Friedman and Mark Selden. New York: Random House, 1971, pp. 146-206.

"Occupied Japan as History and Occupation History as Politics," Journal of Asian Studies 34.2:485-504 (February 1975).

Dulles, John Foster. War or Peace. New York: Macmillan, 1953.

Dunn, Frederick S. Peace-Making and the Settlement with Japan. Princeton: Princeton University Press, 1963.

Fallows, James. "Is Japan the Enemy?" New York Review of Books 38.10:31-37 (May 30, 1991).

Forrestal, James. The Forrestal Diaries. Edited by Walter Millis. New York: Viking Press, 1951.

Gallicchio, Marc S. "The Best Defense is a Good Offense: The Evolution of American Strategy in East Asia, 1953-1960," The Great Powers in East Asia, 1953-1960. Edited by Warren I. Cohen and Akira Iriye. New York: Columbia University Press, 1990.

Griswold, A. Whitney. The Far Eastern Policy of the United States. New Haven, Connecticut: Yale University Press, 1962.

Hellmann, Donald C. Japan and East Asia: The New International Order. New York: Praeger Press, 1972.

"Japanese Security and Postwar Japanese Foreign Policy," The Foreign Policy of Modern Japan. Edited by Robert A. Scalapino. Berkeley: University of California Press, 1977, pp. 321-340. 
"The United States and Asia in an Age of International Upheaval," Current History 91.569:401-406 (December 1992).

Igarashi Takeshi. "Peace-Making and Party Politics: The Formation of the Domestic Foreign-Policy System in Postwar Japan," Journal of Japan Studies 11.2:323-356 (Summer 1985).

Inoguchi, Takashi, and Daniel I. Okimoto (eds.). The Political Economy of Japan: The Changing International Context. Vol. II. Stanford: Stanford University Press, 1988.

Iriye, Akira. Across the Pacific: An Inner History of American - East Asian Relations. New York: Harcourt, Brace and World, 1967.

The Cold War in Asia: A Historical Introduction. Englewood Cliffs, New Jersey: Prentice-Hall, 1974.

"Continuities in U.S.-Japanese Relations, 1941-1949," The Origins of the Cold War in Asia. Edited by Yonosuke Nagai and Akira Iriye. New York:

Columbia University Press, 1977, pp. 378-407.

Johnson, Chalmers. MITI and the Japanese Miracle: The Growth of Industrial Policy, 1925-1975. Stanford: Stanford University Press, 1982.

Kennan, George F. American Diplomacy. Exp. ed. Chicago: University of Chicago Press, 1984.

"Japanese Security and American Foreign Policy," Foreign Affairs 43.1:14-28 (October 1964).

Memoirs, 1925-1950. Vol. I. Boston: Little, Brown and Company, 1967.

Memoirs, 1950-1963. Vol. II. Boston: Little, Brown and Company, 1972.

Kolko, Joyce and Gabriel Kolko. The Limits of Power. New York: Harper and Row, 1972.

Kondo Shigekatsu. "Japanese Response to the Korean War," The Occupation of Japan: The Impact of the Korean War (Proceeding of the Seventh Symposium Sponsored By the General Douglas MacArthur Foundation - October 1986). Edited by William F. Nimmo. Norfolk, Virginia: The General Douglas MacArthur Foundation, 1990, pp. 7-13. 
LaFeber, Walter. America, Russia, and the Cold War, 1945-1980. 4th. ed. New York: John Wiley and Sons, 1980.

Langer, Paul F. Japanese National Security Policy -- Domestic Determinants. Santa Monica, California: Rand, 1972.

Livingston, Jon, Joe Moore and Felicia Oldfather (eds.). Postwar Japan: 1945 to the Present. New York: Random House, 1973.

Mahbubani, Kishore. "Japan Adrift," Foreign Policy (Fall 1992), pp. 126-144.

Makato Momoi. "Basic Trends in Japanese Security Policies," The Foreign Policy of Modern Japan. Edited by Robert A. Scalapino. Berkeley: University of California Press, 1977. pp. 341-364.

Manchester, William. American Caesar: Douglas MacArthur 1880-1964. Boston: Little, Brown and Company, 1978.

Masumi Junnosuke. Postwar Politics in Japan, 1945-1955. trans. by Lonny E. Carlile. Berkeley: Institute of East Asian Studies, University of California, 1985.

Mayers, David. George Kennan and the Dilemmas of U.S. Foreign Policy. New York: Oxford University Press, 1988.

McCullough, David. Truman. New York: Simon and Schuster, 1992.

Miki Hideo. "Aspects of U.S. Strategy For the Defense of Japan," The Occupation of Japan: The Impact of the Korean War (Proceeding of the Seventh Symposium Sponsored By the General Douglas MacArthur Foundation October 1986). Edited by William F. Nimmo. Norfolk, Virginia: The General Douglas MacArthur Foundation, 1990, pp. 45-53.

Morgenthau, Hans J. "The Mainsprings of American Foreign Policy," A Reader in American Foreign Policy. Edited by James M. McCormick. Itasca, Illinois: F.E. Peacock Publishers, 1986, pp. 33-51.

Morris, I. I. Nationalism and the Right Wing in Japan: A Study of Post-War Trends. London: Oxford University Press, 1960.

Nakane, Chie. Japanese Society. Berkeley: University of California Press, 1970.

Olsen, Edward A. U.S.-Japan Strategic Reciprocity: A Neo-Internationalist View. Stanford: Hoover Institution Press, 1985. 
Pruessen, Ronald W. John Foster Dulles: The Road to Power. New York: The Free Press, 1982.

Pyle, Kenneth B. "Japan's Pacific Overtures: How Japan Sees Itself at Home, in Asia, and Around the World," The American Enterprise (NovemberDecember 1991), pp. 30-37.

The Making of Modern Japan. Lexington, Massachusetts: D.C. Heath and Company, 1978.

Sapin, Burton. "The Role of the Military in Formulating the Japanese Peace Treaty," History of Military Affairs in Western Society Since the 18th Century. Edited by Gordon B. Turner. New York: Harcourt, Brace and Company, 1953.

Schaller, Michael. The American Occupation of Japan: The Origins of the Cold War in Asia. New York: Oxford University Press, 1985.

Schonberger, Howard. "The Japan Lobby in American Diplomacy, 1947-1952," Pacific Historical Review 46.3:327-359 (August 1977).

Sebald, William J. and Russell Brines. With MacArthur in Japan: A Personal History of the Occupation. New York: W.W. Norton and Company, 1965.

Spence, Jonathan D. The Search for Modern China. New York: W.W. Norton and Company, 1990.

Staff of Asahi Simbun. The Pacific Rivals: A Japanese View of Japanese-American Relations. New York: Weatherhill/Asahi, 1972.

Stockwin, J.A.A. The Japanese Socialist Party and Neutralism: The Study of a Party and Its Foreign Policy. London: Melbourne University Press, 1968.

Supreme Commander of the Allied Powers. Report of Government Section. Political Reorientation of Japan: September 1945 to September 1948. Vol. II. Grosse Pointe, Michigan: Scholarly Press, 1968.

Swearingen, A. Rodger. Communist Strategy in Japan, 1945-1960. Santa Monica, California: Rand, 1965.

U.S. Department of State. Department of State Bulletin.

Foreign Relations of the United States. Abbreviated in the notes as FRUS. 
U.S. House of Representatives, Committee on Foreign Affairs. U.S. Policy in the Far East: Selected Executive Session Hearings of the Committee, 1951-1956. Vol. XVII. Washington, D.C.: U.S. Government Printing Office, 1980.

U.S. Senate. Executive Sessions of the Senate Foreign Relations Committee (Historical Series). Vol. III, pt. I. 82nd Congress, 1st Session. 1951. Washington D.C.: U.S. Government Printing Office, 1976.

Executive Sessions of the Senate Foreign Relations Committee (Historical Series). Vol. IV. 82nd Congress, 2nd Session. 1952. Washington, D.C.: U.S. Government Printing Office, 1976.

Weinstein, Martin. Japan's Postwar Defense Policy, 1947-1968. New York: Columbia University Press, 1971.

Wildes, Harry Emerson. "Underground Politics in Post-war Japan," The American Political Science Review 42.6:1149-1180 (December 1948).

Williams, W. A., Thomas McCormick, Lloyd Gardner, and W. LaFeber (eds.). America in Vietnam: A Documentary History. New York: Anchor Books, 1985.

Wolferen, Karel van. "The Japan Problem Revisited," Foreign Affairs 69.4:42-55 (Fall 1990).

Yoshida Shigeru. "Japan and the Crisis in Asia," Foreign Affairs 29.2:171-181 (January 1951).

The Yoshida Memoirs: The Story of Japan in Crisis. Westport, Connecticut: Greenwood Press, 1973.

"Japan: Costly Base for U.S.," U.S. News \& World Report 28.7:26-27 (February 17, 1950). 
APPENDIX A

ARTICLE IX OF THE JAPANESE CONSTITUTION 
Aspiring sincerely to an international peace based on justice and order, the Japanese people forever renounce war as a sovereign right of the nation and the threat or use of force as a means of settling international disputes.

2. In order to accomplish the aim of the preceding paragraph, land, sea, and air forces, as well as other war potential, will never be maintained. The right of belligerency of the State will not be recognized. 
APPENDIX B

TEXT OF THE UNITED STATES-JAPAN BILATERAL SECURITY TREATY 
Japan has this day signed a Treaty of Peace with the Allied Powers. On the coming into force of that Treaty, Japan will not have the effective means to exercise its inherent right of self-defense because it has been disarmed. There is danger to Japan in this situation because irresponsible militarism has not yet been driven from the world. Therefore, Japan desires a Security Treaty with the United States of America to come into force simultaneously with the Treaty of Peace between the United States of America and Japan. The Treaty of Peace recognizes that Japan as a sovereign nation has the right to enter into collective security arrangements, and further, the Charter of the United Nations recognizes that all nations possess an inherent right of individual and collective self-defense.

In exercise of these rights, Japan desires, as a provisional arrangement for its defense, that the United States of America should maintain armed forces of its own in and about Japan so as to deter armed attack upon Japan.

The United States of America, in the interest of peace and security, is presently willing to maintain certain of its armed forces in and about Japan, in the expectation, however, that Japan will itself increasingly assume responsibility for its own defense against direct and indirect aggression, always avoiding any armament which could be an offensive threat or serve other than to promote peace and security in accordance with the purposes and principles of the United Nations Charter.

Accordingly, the two countries have agreed as follows: 
Article I. Japan grants, and the United States of America accepts the right, upon the coming into force of the Treaty of Peace and of this Treaty, to dispose United States land, air, and sea forces in and about Japan. Such forces may be utilized to contribute to the maintenance of the international peace and security in the Far East and to the security of Japan against armed attack from without, including assistance given at the express request of the Japanese Government to put down large-scale internal riots and disturbances in Japan, caused through instigation or intervention by an outside Power or Powers.

Article II. During the exercise of the right referred to in Article I, Japan will not grant, without prior consent of the United States of America, any bases or any rights, power, or authority whatsoever, in or relating to bases or the right of garrison or of maneuver, or transit of ground, air, or naval forces to any third Power.

Article III. The conditions which shall govern the disposition of armed forces of the United States of America in and about Japan shall be determined by administrative agreements between the two Governments.

Article IV. This Treaty shall expire whenever in the opinion of the Governments of the United States of America and of Japan there shall have come into force such United Nations arrangements or such alternative individual or collective security dispositions as will satisfactorily provide for the maintenance by the United Nations or otherwise of international peace and security in the Japan Area. 
Article $V$. This Treaty shall be ratified by the United States of America and Japan and will come into force when instruments of ratification thereof have been exchanged by them at Washington.

IN WITNESS WHEREOF the undersigned plenipotentiaries have signed this Treaty.

DONE in duplicate at the city of San Francisco, in the English and Japanese languages, this eighth day of September, 1951. 